NBER WORKING PAPER SERIES

\title{
OPIOID USE, HEALTH AND CRIME: \\ INSIGHTS FROM A RAPID REDUCTION IN HEROIN SUPPLY
}

\author{
Timothy J. Moore \\ Kevin T. Schnepel \\ Working Paper 28848 \\ http://www.nber.org/papers/w28848 \\ NATIONAL BUREAU OF ECONOMIC RESEARCH \\ 1050 Massachusetts Avenue \\ Cambridge, MA 02138 \\ May 2021
}

We thank Mark Anderson, Scott Cunningham, Monica Deza, Mirko Draca, Bill Evans, Mario Fiorini, Seth Freedman, Mike Grossman, Alex Hollinsworth, Thomas Lemieux, Ethan Lieber, Jens Ludwig, Mike Mueller-Smith, Rosalie Pacula, Chris Ruhm, Kosali Simon, Peter Siminski, Rosanna Smart, Cody Tuttle, and Don Weatherburn for helpful comments as well as conference/ seminar participants at NBER Summer Institute Health Economics Program 2018, Chicago/LSE Conference on the Economics of Crime and Justice 2019, the Texas Economics of Crime Workshop 2019, Clemson University, Indiana University at Bloomington, Indiana UniversityPurdue University at Indianapolis, San Diego State University, University of Adelaide, University of British Columbia, University of Manitoba, University of Melbourne, University of Technology Sydney, and University of Victoria. We thank the NSW Center for Health Record Linkage and the NSW Bureau of Crime Statistics and Research for data linkages and support. Moore gratefully acknowledges financial support from an Australian Research Council Discovery Early Career Research Award (DE170100608). The views expressed herein are those of the authors and do not necessarily reflect the views of the National Bureau of Economic Research.

NBER working papers are circulated for discussion and comment purposes. They have not been peer-reviewed or been subject to the review by the NBER Board of Directors that accompanies official NBER publications.

(C) 2021 by Timothy J. Moore and Kevin T. Schnepel. All rights reserved. Short sections of text, not to exceed two paragraphs, may be quoted without explicit permission provided that full credit, including $\odot$ notice, is given to the source. 
Opioid Use, Health and Crime: Insights from a Rapid Reduction in Heroin Supply Timothy J. Moore and Kevin T. Schnepel

NBER Working Paper No. 28848

May 2021

JEL No. I12,K42

\begin{abstract}
$\underline{\text { ABSTRACT }}$
In 2001, a large and sustained supply shock halted a heroin epidemic in Australia. We use outpatient drug treatment records to identify individuals who accounted for nearly half of opioid overdoses prior to the shock, and examine how the reduced supply of heroin affected their health and criminal activity over the next eight years. Initially, the gains from fewer overdose deaths are offset by individuals substituting to other drugs and committing more violent crime, including homicides. Most adverse effects dissipate after one year, and are followed by further decreases in deaths and a large reduction in property crime. Our results demonstrate that reducing the supply of illicit opioids can lead to meaningful longer-term improvements, even when the short-term effects are ambiguous.
\end{abstract}

Timothy J. Moore

Department of Economics

Purdue University

403 W. State Street

West Lafayette, IN 47907

and NBER

moore839@purdue.edu

Kevin T. Schnepel

Department of Economics

8888 University Drive

Simon Fraser University

Burnaby, British Columbia, V5A 1S6

Canada

kevin_schnepel@sfu.ca 
Illicit drugs are associated with many adverse outcomes, including premature mortality, violent behavior, child neglect and property crime (Manski, Pepper and Petrie 2001, Reuter 2010). In the midst of a drug "epidemic" — when drug use is intense and widespread - these problems have profound effects on community wellbeing and public safety (Moore and Pacula 2020). Prominent US examples of drug epidemics include the crack cocaine epidemic of the 1980s and 1990s and the current opioid crisis, which resulted in more than 50,000 opioid overdose deaths in 2019 (Ahmad, Rossen and Sutton 2020).

In response to drug epidemics, governments often target suppliers by increasing drug law enforcement. During the crack cocaine epidemic, the US government escalated its "war on drugs," scaling up interdiction operations and sending nearly 500,000 drug offenders to prison or jail by the early 2000s (Raphael and Stoll 2013). Recently, as the opioid crisis has become dominated by illicit opioids - heroin and fentanyl accounted for around 85\% of US opioid overdose deaths in 2019 - the federal government has increased interdiction efforts along with prosecutions and penalties for supplying them (Bipartisan Policy Center 2020, U.S. Sentencing Commission 2020). Even in countries known for more lenient enforcement regimes, such as Australia, The Netherlands and Sweden, spending on drug law enforcement dwarves the funding of treatment and prevention (Moore 2008).

There is skepticism about the value of such interventions, even if they reduce supply. Since the demand for illicit drugs is often inelastic, a drop in supply can increase both a seller's profit and a buyer's acquisitive crime (Becker, Murphy and Grossman 2006, MacCoun, Kilmer and Reuter 2003). Market disruptions can destabilize relationships between drug suppliers, leading to more violence as domestic suppliers try to gain or protect market share (Levitt and Venkatesh 2000, Caulkins and Reuter 2010). Consumers may respond to higher prices by substituting to other drugs, offsetting any benefits from reducing the availability of the drug targeted by enforcement efforts (Manski, Pepper and Petrie 2001). As a result, prominent scholars argue that "the war on drugs may increase addiction rates and even the number of addicts" (Becker and Murphy 2013) and that, in the current opioid crisis, "measures to cut access to opioids offer illusory solutions" (Dasgupta, Beletsky and Ciccarone 2018: 182).

Occasionally, a law enforcement intervention reduces the supply of an illicit drug. These supply shocks provide the best opportunity to understand the net effects of reducing supply, but two empirical challenges have limited their usefulness. First, as Dobkin and Nicosia (2009) note, most shocks are too small and temporary to allow researchers to measure the consequences. For example, in their study of the impacts of a major disruption in 1995 to the supply of a methamphetamine precursors in California, the effect of the shock on methamphetamine prices lasted only four months. And this is one of the larger effects identified within the 
literature. The second challenge is in terms of data quality since data on individual drug users are rarely available. Aggregate data make it difficult to accurately estimate drug substitution and the impacts on non-drug-defined crime (Cawley and Ruhm 2011, Manski, Pepper and Petrie 2001). It is almost impossible to understand the net mortality effects without being able to identify individual drug users, because changes in other causes of death are obscured in population-level data. Consequently, we know little about the effectiveness of supply-side interventions in addressing drug problems (Reuter 2017, Smart et al. 2020).

In this paper, we overcome these limitations by studying the consequences of a large, sustained reduction in Australia's heroin supply using individual-level data that covers health and crime outcomes. Australia experienced a major heroin epidemic during the 1990s; by 1999, as many people in Sydney and Melbourne were dying from opioid overdoses as from traffic accidents (Lancaster et al. 2011). Then, in late 2000, the availability of heroin declined rapidly and its price soared. As discussed in the next section, this was likely due to increased drug interdiction efforts ending the smuggling of large quantities of heroin in shipping containers, which forced suppliers to use far less efficient methods. In less than one year, the purityadjusted price of heroin increased by $400 \%$, due to both higher street prices and lower drug purity. Figure 1 shows that prices remained high for many years, and opioid overdose deaths fell by approximately $60 \%$. $^{1}$

We examine this large supply shock using individual-level administrative data from the state of New South Wales (NSW), Australia's most populous state. We use NSW's medicationassisted treatment system (e.g., for methadone) to identify 27,487 individuals treated for opioid addiction in the years prior to the heroin supply shock. This information is linked to mortality and criminal justice data, producing a panel that spans six years before and eight years after the onset of the heroin supply reduction. In our setting, medication-assisted treatment only requires a prescription from a primary care physician. It has no counselling or drug testing requirements, and is free or cheap to all individuals (i.e., <US\$25 per week). Even though our sample includes just one in every 220 residents in NSW, it accounts for approximately half of the state's opioid overdose deaths prior to the market disruption. This is remarkable coverage of an illicit drug market; we are unaware of another study in

\footnotetext{
${ }^{1}$ Prices are constructed by dividing average retail heroin prices by heroin purity. Data on the prices paid for a dose ("cap") of heroin are from the Illicit Drug Reporting System and purity data are from the Victoria Police Forensic Science Centre. Data are not available prior to 1998. The methodology is similar to other studies examining illicit drug prices (e.g., Moore 2006, Arkes et al. 2008). Mortality data come from the Australian Institute of Health and Welfare. Opioid-related deaths are defined in accordance with the Australian Bureau of Statistics (2002), based on similar ICD codes to those in the US. Prior to 1997, opioid-related deaths are those with ICD-9 underlying-cause-of-death codes E850.0, E850.8, E850.9, 304.0, 304.7, 304.9, 305.5 or 305.9. From 1998, opioid-related deaths are those with an ICD-10 underlying-cause-of-death code of X42, $\mathrm{X} 44, \mathrm{X} 62, \mathrm{X} 64$, X85, Y12, or Y14 together with an opioid drug identification code of T40.0-T40.4.
} 
which a similar proportion of drug overdoses can be identified in individual-level longitudinal data. ${ }^{2}$ Treatment records provide much broader coverage than arrests: individuals with an opioid drug offense represent approximately $10 \%$ of the opioid overdose deaths prior to the supply reduction. ${ }^{3}$ We use event-study approaches to identify the impact of the heroin supply reduction on these opioid users and include specifications that use a comparison group of non-opioid drug offenders to account for other factors affecting drug use, health and criminal activity. In general, the direction and magnitude of our effects are similar with and without the comparison group.

We first examine drug-specific outcomes. The heroin supply reduction leads to immediate and persistent declines in opioid-related mortality and arrests for opioid possession that are on the order of $40-60 \% .{ }^{4}$ Given the size of the price shock, our estimates imply ownprice elasticities of demand of around -0.1 in the short term and -0.15 in the longer term. Opioid users substitute to non-opioid illicit drugs in the first year after the onset of the heroin supply shock; offenses for cocaine possession offenses double and methamphetamine possession offenses increase by around 50\%. These results imply that the opioid users in our sample have short-term cross-price elasticities for cocaine and amphetamine of 0.45 and 0.12 , respectively. After the first year, cocaine possession offenses return to baseline levels, but there is mixed evidence on the longer-term use of methamphetamine. Persistent increases in methamphetamine possession offenses that are evident with the comparison group largely disappear without it. (This is the only outcome where the results are qualitatively different with and without the comparison group). A small increase in mortality from causes related to non-opioid drug use provides further evidence that there is some substitution to other drugs once the supply of heroin is reduced.

We then consider the broader impacts on mortality and crime. There is a large and sustained drop in overall mortality rates. It is around $80 \%$ as large as the decrease in opioid-related mortality, implying that direct mortality improvements are slightly offset by increases in mortality related to non-opioid drug use and other competing mortality risks. The crime effects differ depending on the type of offense. Violent offenses increase by approximately $30 \%$

\footnotetext{
${ }^{2}$ As a comparison, Dobkin and Puller (2007) find that Supplemental Security Income and Welfare recipients in California - which cover around $8 \%$ of the population - account for approximately $30 \%$ of California hospital admission records with a drug mention.

${ }^{3}$ Coverage is going to be greatest where addiction treatment is widespread. However, even in the US the 1.36 million outpatients receiving opioid medication-assisted treatment in 2019 is far greater than 0.33 million arrested for opioid-related and other narcotic-related offenses (which includes cocaine) (National Survey of Substance Abuse Treatment Services 2020; authors' calculations from the Federal Bureau of Investigation's Crime Data Explorer https://crime-data-explorer.app.cloud.gov/). This demonstrates the value of using treatment records for research (Smart et al. 2020).

${ }^{4}$ Our data allows us to identify opioid deaths and opioid drug charges, but not more specific types like heroin.
} 
in the first year, driven by large increases in homicides and assaults. Most violent offenses return to baseline levels by the third year and remain stable thereafter, although assaults remain 15\% higher than before the heroin supply reduction. Property offenses decline after the first year and decrease by around $60 \%$ over the longer term. However, not all types of property crime follow this pattern; robbery is elevated throughout the eight years after the heroin supply is reduced, while burglary and motor vehicle theft spike in the first year before declining over the longer term. These results are consistent with most opioid users decreasing their drug use and criminal activity after the heroin supply is reduced, while a small number become more violent, including undertaking more violent acquisitive crime in order to fund a more expensive drug habit.

To understand the net impact of the heroin supply shock on our large sample of opioid users, we use information on the value of statistical life and crime costs to aggregate the effects. Back-of-the-envelope calculations suggest the net present value is uncertain after the first year, with mortality savings offset by crime costs. For longer periods of time, however, there are large savings in the net present value. In 2019 dollars, the net present value at the time of the supply shock is around A $\$ 3.7$ billion (US $\$ 2.7$ billion) when evaluated over eight years, or around $\mathrm{A} \$ 136,000$ (US $\$ 97,000$ ) per opioid user in our sample. Persistent mortality reductions over the eight years - which are estimated to save the lives of around one in every 50 individuals in our sample - are a key driver of these substantial gains. The net present value is high relative to federal drug interdiction expenditures around this time. State-level changes in opioid overdoses and crime rates suggest that the impacts on opioid users not included in our sample increase these savings.

This research contributes to the literature on illicit drug supply shocks that spans economics, criminology, epidemiology and public health. Most directly, our findings provide a deeper understanding of the consequences of the Australian heroin supply reduction, which has generated substantial interest as one of the better-known supply shocks in the world. Studies have documented that it decreased opioid use and overdoses, but there have been mixed results for most other outcomes (e.g., Day et al. 2003, Degenhardt et al. 2004, Donnelly et al. 2004, Weatherburn et al. 2003). These studies do not use individual-level panel data and largely focus on the first few years after the supply reduction. We also document broader effects than previous economic studies of other drug supply shocks, primarily because the length and structure of our data delivers much greater precision than has previously been possible (e.g., Dobkin and Nicosia 2009, Dobkin et al. 2014, Cunningham and Finlay 2013, 2016, d'Este 2021). ${ }^{5}$ For example, Dobkin and Nicosia (2009) find that the 1995 methamphetamine supply

\footnotetext{
${ }^{5}$ For reviews of the broader literature on drug supply shocks outside of economics, see Caulkins and Reuter
} 
shock in California halved methamphetamine hospital admissions and methamphetamine use among arrestees, but do not find any impacts on the demand for other drugs or on property or violent crime. Our ability to precisely identify such effects and describe how they evolve over time means that we deliver several new insights into what happens when the supply of an illicit drug is reduced.

Two novel insights are especially relevant to addressing problems related to the use of heroin and other illicit opioids. We are the first to use exogenous variation to estimate the degree of substitution between using heroin and using cocaine and methamphetamines among a population of heroin users. In the US opioid crisis, policies aimed at reducing the supply of prescription opioids have had perverse effects on the demand for illicit opioids (Alpert, Powell and Pacula 2018, Evans, Lieber and Power 2019). We show that when the opioids driving the epidemic only have more expensive substitutes, as was the case for heroin in our setting and is currently the case for heroin and fentanyl in the US opioid crisis, the substitution to other hard drugs may be temporary. ${ }^{6}$

Our second key insight is the degree to which reductions in fatal opioid overdoses are offset by competing mortality risks (Honoré and Lleras-Muney 2006, Swensen 2015). Studies across Australia, Europe, and the US have documented that opioid users have elevated mortality risks across many causes of death (Bargagli et al. 2006, Degenhardt et al. 2011). We find competing risks to be a relevant concern, but that approximately $80 \%$ of the gains from reduced opioid-related deaths translate into lives saved. Policy-makers often use opioid overdoses to evaluate policy progress, and these insights provide a better understanding of the likely net mortality gains underlying such changes.

We also advance the understanding of the relationship between drugs and crime (MacCoun et al. 2003, Reuter 2017). ${ }^{7}$ One finding is that market disruptions can increase violence, even in a developed country with relatively low levels of violent crime. ${ }^{8}$ Studies have documented

\footnotetext{
(2010), Werb et al. (2011), and Pollack and Reuter (2014).

${ }^{6}$ See Grossman (2005), Reuter (2010), and Gallet (2014) for reviews of the demand for illicit drugs. Among studies examining drug supply reductions, Cunningham and Finlay (2016) find mixed evidence on whether methamphetamine users substitute to cocaine after precursor laws reduce supply, and other studies find no effects. After adjusting for potency, prescription opioids are much more expensive than heroin and fentanyl (Evans, Lieber and Power 2019). See Moore and Pacula (2020) for a discussion of how cheap illicit drugs drive epidemics.

${ }^{7}$ Among economics studies examining supply shocks and crime, we are only aware of d'Este (2021) finding a link (that methamphetaine precursor laws increase county-level crime). However, Dobkin, Nicosia and Weinberg (2014) use similar variation and find no drugs-crime relationship. Others finding a link between drugs and crime include Corman and Mocan (2000); Grogger and Willis (2000); Kuziemko and Levitt (2004); Adda et al. (2014); Evans, Garthwaite and Moore (2016); Bondurant, Lindo and Swensen (2018); and Dave, Deza and Horn (2021).

${ }^{8}$ At the time of the heroin supply reduction, Australia's homicide rate was approximately one third the size
} 
increases in homicides in Mexico and Colombia as a result of market disruptions (e.g. Dell 2015, Castillo, Mejía and Restrepo 2020), but studies in developed countries find no such relationship. Opioid users in our sample committed 23 murders in 2001, the first year of the heroin supply reduction. This was a $700 \%$ increase from the previous year and represented one fifth of all murders in NSW that year. Although the effects dissipate after that first year, this study validates concerns that drug market disruptions can increase violence among drug users.

Another crucial aspect of the drugs-crime relationship is the link between drug use, drug prices and property crime. Manski, Pepper and Petrie (2001) note that while some policy analysts believe that illicit drug users "will 'do anything' and 'pay anything' to consume drugs," the fact that people addicted to legal drugs like alcohol and tobacco make serious efforts to quit after a price increase suggests illicit drug users might do the same (p. 142). Our property-crime results support the latter view, especially after the first year.

Finally, we highlight the need to evaluate supply-side drug policies over several years. Economists have highlighted how short- and long-run demand elasticities for addictive goods are different (Becker and Murphy 1988, Grossman 2005). Likewise, the impact of reduced supply can look very different over time. After one year, there were fewer overdoses but more homicides and other types of violent crime in addition to some types of property crime. Beyond that, the net benefits changed from ambiguous to sizeable as opioid users reduced their drug consumption and levels of criminal activity. Studies with a limited follow-up period are unlikely to be informative about supply-side interventions, leaving us no clearer about the merits of the "war on drugs."

Australia is similar to other developed countries in terms of its drug laws, types of drugs available, and levels of addiction. Until recently, Australia's opioid epidemic of the 1990s was close in scale to the opioid crisis in the US. Figure 1b shows opioid-related mortality rates in NSW and in US 14 years apart. ${ }^{9}$ The increasing mortality rate in the US from 1999 to 2013 closely tracks NSW from 1986 to 1999; after that, the two series diverge as deaths in NSW fell in response to the heroin supply shock while deaths in the US continued to rise. The price sensitivity of opioid users in our sample is also comparable to estimates for heavy illicit drug users in the US. ${ }^{10}$ These features suggest our findings can be informative about

of the US rate and similar to Europe (authors' calculations from https://dataunodc. un.org/ [Accessed 19 April 2021]).

${ }^{9}$ The Australian data are from Figure 1. US data are from CDC Wonder (https://wonder.cdc.gov/mcd. html). We use the same ICD-10 codes as outlined in footnote 2 to improve comparability, which covers $91 \%$ of the opioid overdoses defined by the CDC (Ahmad et al. 2020).

${ }^{10}$ Our results imply own-price elasticities for opioid mortality and opioid use offenses of around -0.1 in the short term and -0.15 in the longer term. In the US, Dave (2006) estimates an own-price elasticity for heroin 
the effects of reducing the supply of illicit drugs elsewhere, especially among individuals who have contact with outpatient drug treatment services. ${ }^{11}$

Our study provides little guidance on how law enforcement should try to reduce supply. Like law enforcement successes with methamphetamine precursor chemicals in the US, Australia's interdiction efforts for heroin benefited from the market being supplied by a small number of sophisticated crime syndicates. While other supply-side interventions may not achieve the size and persistence of the shock that we study, it is these features that enable us to gain a detailed understanding of how supply-side interventions affect the adverse consequences of illicit drug markets.

The remainder of the paper proceeds as follows. We describe key features of illicit drug markets in Australia in Section 2, including how the heroin supply fell from late 2000. We outline the empirical approach in Section 3 and describe the data in Section 4. In Section 5 , we analyze the impact of the heroin supply reduction on mortality and crime outcomes. In Section 6, we evaluate the net impacts of this reduction, consider how they changed over time, and provide concluding remarks.

\section{Background}

\subsection{Opioids and Other Drugs in Australia}

Opioids have long been used in Australia, originally in medicines and by Chinese migrants who smoked opium and heroin. Various bans and restrictions on opioids were introduced from early in the 20th century, before heroin importation was banned in 1953. Australia committed to international drug control rules by signing the United Nations Single Convention on Narcotic Drugs in 1961 and ratifying it in 1967.

A small heroin market developed during the Vietnam War, when American soldiers on leave in Sydney created demand for the drug and introduced it to locals. Most heroin during this time came from Thailand via body or baggage concealment methods on commercial airlines, or via mail. These methods continued until the 1990s, when South East Asian trafficking groups began to supply cheaper heroin than previously available. According to law enforcement agencies, these groups imported heroin in shipping containers. This resulted in a handful of

emergency room admissions of -0.1, while Dave (2008) estimates heroin participation elasticities for arrestees of -0.1 in the short term and -0.26 in the long term. For methamphetamine users, Cunningham and Finlay (2016) estimate an own-price drug treatment elasticity of -0.13 to -0.17 , while the results in (Dobkin and Nicosia 2009) imply similar estimates.

${ }^{11}$ As described in footnote 3, 1.36 million Americans participated in medication-assisted treatment in 2019, making it likely that several million have done so in recent years. Treatment participation is even higher in Europe, where $80 \%$ of opioid treatment admissions are for heroin (EMCDDA 2019). 
large importers supplying heroin into Australia (Degenhardt, Reuter et al. 2005, Caulkins and Reuter 2010).

During the 1990s, there was a large increase of heroin coming into Australia. One indication of this was the rapid rise in opioid-related deaths, as shown in Figures 1a and 1b. States other than NSW showed a similar increase. Heroin became cheaper, and injecting drug users reported heroin as the drug they used most frequently (Topp et al. 2002). The most common drug treatment was for opioids, mainly for heroin (Degenhardt et al. 2004).

Other illicit drugs were available around this time, with amphetamines and cocaine the most common 'harder' drugs available. Various forms of amphetamines have long been available in Australia, including methamphetamine (also referred to as 'speed' and 'base'), crystal methamphetamine ('ice' and 'crystal meth') and MDMA ('ecstasy'). Domestically produced speed was a common form of the drug in Australia, although crystal meth became available in Australia in the 1990s and provided a higher-purity form of the drug that was commonly injected. As such, it was a closer substitute to heroin than other forms of methamphetamine. Methamphetamines were smuggled from Asia, especially China. There was potentially some overlap between methamphetamine and heroin trafficking, although the source countries and key suppliers were thought to be different (Pieper 2006). The cocaine market was described as operating through tight social networks, perhaps reducing its visibility in terms of use and social problems. Crack cocaine use was rare and has never been a prominent form of cocaine in Australia. Cocaine was sometimes seized at the Australian border during the late 1990s, although typically in small quantities and separately to heroin and other drugs (Shearer et al. 2008).

Drug prices from surveys of injecting drug users suggest that impure per-dose prices of methamphetamine and cocaine were around 25-50\% more expensive than for heroin (Topp et al. 2002). To understand how prices changed in these other illicit drug markets in Appendix Figure A1 we show the purity-adjusted prices of heroin, methamphetamine and cocaine between 1998 and 2008 relative to the year 2000. ${ }^{12}$ The changes in heroin prices in 2001 dwarf changes in the relative prices of amphetamines and cocaine over this period. Cocaine prices are stable throughout while amphetamine prices decline over time, with most of the decrease occurring prior to 2001. The decline in the amphetamine price may reflect a changing mix of amphetamine substances being used and seized; unfortunately, specific types are not identified in these data. Caulkins et al. (2006) examined forensic data for both heroin and

\footnotetext{
${ }^{12}$ As for the price data in Figure 1, this is constructed by dividing retail prices from a survey of regular injecting drug users by average drug purities from police forensic analyses of retail-level quantities. The survey was completed by August, so data for year 2000 was prior to the supply reduction. Please see appendix for more details.
} 
amphetamines in Australia, and found no change in amphetamine purity in response to the heroin supply reduction.

Prescription opioids, another potential substitute to heroin, were misused in Australia during the 1990s. The most common prescriptions were for methadone and morphine, with oxycodone and hydromorphone used more from the late 1990s. In 1998, opioids other than heroin accounted for $23 \%$ of opioid overdose hospitalizations, with a further $12 \%$ not attributed to a specific opioid. As shown in Appendix Figure A2, Australia experienced a six-fold increase in opioid prescriptions between 1990 and 2012. Australia and the US has similar prescription opioid rates during most of the 1990s, after which the rise in the US has outpaced Australia's. International comparisons of illicit drug markets are difficult, but data from the United Nations Office for Drugs and Crime suggest Australia's illicit drug prices are similar to other developed countries. For example, in 1999 their data on the retail price for a gram of heroin in Europe and the US suggest that Australia's heroin price was seventh-most expensive of 19 countries, with higher prices in Finland, Ireland, United States, Denmark, Switzerland and Norway (see Appendix Figure A3). Around this time, Reuter (2009) examined illicit drug markets in Australia, the US, Canada and 15 European countries and noted a "marked similarity in drug trends (if not in levels of drug problems)" (p. 21).

\subsection{The Reduction in Heroin Supply}

A large reduction in the supply of heroin appeared across Australia in late 2000. It was specific to Australia, suggesting that it was not related to general changes in international heroin markets. Degenhardt, Reuter et al. (2005) evaluated possible explanations for it and concluded that drug law enforcement was likely to be the primary cause. The Australian Federal Police (AFP), the primary agency responsible for drug interdiction, received substantial extra funding in the late 1990s to establish overseas operations near drug trafficking routes in Asia and mobile 'strike teams' aimed at dismantling trafficking groups. As shown in Appendix Figure A2, AFP funding and its presence in Asia doubled from the 1997 to 2000 financial years. Other agencies also received funding for more customs screening and to detect drug-related money laundering (Degenhardt, Reuter et al. 2005).

These efforts had some success. The AFP seized an average of 127 kilograms of heroin per year over the 1995 to 1997 financial years; over the 1998 to 2000 financial years, the average was 524 kilograms per year. ${ }^{13}$ Interestingly, the number of seizures nearly halved, suggesting that the AFP targeted much larger shipments (see Appendix Figure A4). Caulkins and

\footnotetext{
${ }^{13}$ This is large relative to the heroin consumed in Australia, estimated to be 2-3 metric tons in 1997 (Hall et al. 2000).
} 
Reuter (2010) describe three large seizures of heroin bound for Australia in 2000. The first two seizures, each of around 100 kilograms, occurred in early 2000. In October 2000, a third seizure of 357 kilograms in Fiji included a large number of arrests and shutting down a front company that had been used to facilitate smuggling. According to the AFP, this operation "rendered ineffective a sophisticated concealment methodology, identified a legitimate cargo stream, and removed some very important [smugglers]" (Hawley 2002, pg. 48). Degenhardt, Reuter et al. (2005) cite law enforcement sources who believed that two key groups used shipping containers to smuggle most of the heroin into Australia at this time, and that these two groups withdrew from Australia as a result of this intense drug interdiction. They were replaced by suppliers using small-scale, inefficient methods.

This led to a large increase in heroin prices and a large reduction in opioid overdoses, as shown in Figure 1a. Heroin users reported longer search times and difficulty obtaining heroin. For example, $88 \%$ of injecting drug users surveyed in the middle of 2001 reported that heroin was difficult to obtain; this was in sharp contrast to 12 months before, when $99 \%$ had reported heroin as easy or very easy to obtain (Topp et al. 2002).

As discussed in the introduction, several studies have examined the consequences of the heroin supply reduction. We summarize the approach and findings of 17 studies in Appendix B, which are all of the published studies we could find that examined the effects of the supply shock on opioid use and related outcomes for more than one year after its onset. The key improvement over these studies is our use of individual-level panel data. The primary data in 15 of the studies are time-series counts or rates at the monthly or quarterly level constructed from state or territory administrative data which were typically analyzed using time-series methods. The primary data in two other studies are repeated cross-sectional data from the Illicit Drug Reporting System, an annual survey of injecting drug users. Another contribution is our length of follow-up. Of the 17 studies, 13 track outcomes for three years or less. Only two go beyond four years after the onset of the heroin supply reduction, with Day, Degenhardt and Hall (2006) examining heroin price, purity and self-reported availability for five years and Snowball et al. (2008) examining opioid and amphetamine arrests for 6.25 years.

Prior studies consistently document that measures of heroin and opioid use declined after the supply reduction, and remained low thereafter (Day, Degenhardt and Hall 2006, Donnelly, Weatherburn and Chilvers 2004). The results for other outcomes are weaker and more mixed. For example, Smithson et al. (2004) finds a short-term decline in robbery, Donnelly, Weatherburn and Chilvers (2004) finds a short-term increase in robbery, while Degenhardt, Day, Dietze et al. (2005) finds no change. This is not surprising, given that effects are generally inferred from changes in state-level outcomes or cross-sectional changes in responses from 
illicit drug user surveys. As a consequence, while the size of the initial supply shock is fairly well understood, close to nothing is known about the longer-term consequences on opioid users.

\subsection{Policy Environment}

Australia has a federal structure. State governments have most of the responsibilities for providing local services, such as police, schools and hospitals. NSW is the most populous state. It had 6.5 million residents in 2000, which represented around a third of Australia's population.

Law enforcement. International drug interdiction is the responsibility of the AFP and other agencies that are part of the federal government, such as the Australian Border Force. Each state government has a single, independent police agency that is responsible for all police activities within the state. NSW Police has more than 15,000 police officers and 500 police stations. Budgets for policing are set separately at the federal and state levels.

The resources devoted to policing in NSW were consistent around the time of the heroin supply reduction. This is evident in Appendix Figure A5, which shows the number of operational police officers and NSW Police employees per 100,000 residents from the 1996 to 2007 financial years. The figure also shows that, while per-capita prison capacity and the average number of prisoners increased over this period, it did so at a steady rate of approximately $3 \%$ each year.

Drug laws and policies were also generally consistent over this period. Needle and syringe programs were first established in NSW in the 1980s, and operated throughout the 1990s and 2000s. The introduction of drug courts in 1999 and a safe-injecting facility in 2001 are both policy changes that could have affected drug taking, although in the years after their introduction participation in both was relatively low. ${ }^{14}$ Another change was that the NSW Police got more search powers in 1998 and 2001, which increased the use of occasional crackdowns in major heroin street markets. ${ }^{15}$ Despite these changes, we do not find evidence of major changes in the severity of punishment for various types of offenses, as depicted in Appendix Figure A6. ${ }^{16}$

\footnotetext{
${ }^{14}$ The NSW Drug Court had only around 150 entrants each year through to 2008 (State of NSW 2009). Around 800 individuals visited the safe-injecting facility each month between May 2001 and April 2007 (National Centre in HIV Epidemiology and Clinical Research 2007). Only a subset are likely to be from our sample of 27,467 opioid users.

${ }^{15}$ The Crimes Legislation Amendment (Police and Public Safety) Act 1998 allowed the police to ask people in public places to move on and search those suspected of having weapons. In 2001, it was expanded to allow searches of people suspected of being involved in the drug trade. In the late 1990s, there were occasional crackdowns in street markets in Cabramatta and Central Sydney/Kings Cross (Maher and Dixon 2001, Degenhardt et al. 2004).

${ }^{16}$ We plot the relationship between different types of sanctions and punishment for opioid offenses, non-opioid
} 
Drug treatment. In Australia, the main approach to treating opioid addiction has been to provide methadone under medical supervision. The primary aim is to stabilize and then slowly reduce opioid use, which is a process that can last years. Physicians in general practice or addiction treatment clinics prescribe the methadone, and state governments manage central systems that record each authority to dispense methadone. It is then dispensed daily by a pharmacist or nurse, either at a clinic or community pharmacy. The methadone needs to be consumed in front of the person giving it in order to prevent diversion to the black market, although one or two "takeaway" doses may be allowed each week. Counselling or other support services may be offered, but are not required. Many drop out of treatment early, and multiple treatment episodes are common (Burns et al. 2009). NSW introduced buprenorphine as an option in 2001, although methadone still accounts for the majority of treatment episodes. ${ }^{17}$

Participants pay around $\mathrm{A} \$ 30$ per week for methadone, with some clinics providing it for free. ${ }^{18}$ Treatment capacity can be limited, as new or returning participants in NSW typically receive methadone at specialist clinics until they are judged to be stable. This may take several months; they are then transferred to a community pharmacy. In 2006, NSW had 35 specialist clinics and 600 community pharmacies dispensing methadone; many clinics had waiting lists, although most pharmacies could take on more participants (Winstock et al. 2010).

Other policies. A broader set of policies are also relevant. Universal health insurance provides free access to hospitals and health services. These services were funded in a consistent way before and after the heroin supply reduction. Given the importance of mental health treatment for those with drug addictions, Appendix Figure A5 shows the number of bed and employees devoted to public specialist mental services in NSW. The number of available beds, nearly all of which are in psychiatric hospitals or specialist wards of public hospitals, is flat over this period, while the number of full-time-equivalent employees increased at a steady rate.

Social insurance payments for unemployment and disability are made by the federal government. There are no major reforms to welfare, which have been shown in other contexts to affect welfare (e.g., Giulietti and McConnell 2021). Payment levels change smoothly around

drug offenses, violent and property offenses. We find no large shifts around the heroin supply reduction in the probability of incarceration, average length of incarceration, probability of a fine and the average amount of fine.

${ }^{17}$ Buprenorphine has a lower risk of fatal overdose and longer-lasting effects than methadone, but takes longer to administer, is easier to divert to black markets, and is associated with lower treatment retention (Burns et al. 2009).

${ }^{18}$ Participants may pay a dispensing fee to the pharmacy or clinic; governments pay for doctor visits and the methadone. 
the time of the heroin supply reduction, as shown in Appendix Figure A5. We also plot the unemployment rate, employment-to-population ratio, and average weekly earnings over time in NSW. The economy steadily improved over this period, with the unemployment rate declining from around $7-8 \%$ in 1996 to around $5 \%$ by 2008 . There were no recessions over this period.

\section{Empirical Approach}

We use an event study framework to evaluate the dynamic effects of the heroin supply reduction on various outcomes. We define our treatment group (in terms of the supply reduction) as individuals who participated in medication-assisted opioid treatment prior to the onset of the supply reduction in the fourth quarter of 2000. Across our specifications, we use indicator variables relative to event time to flexibly assess the patterns in outcomes in relation to the onset of the heroin supply reduction.

Our main approach is to use a differences-in-differences event study specification that includes a comparison group of non-opioid illicit drug users. These are individuals arrested for using or possessing a non-opioid illicit drug before the fourth quarter of 2000 who do not participate in opioid treatment. This specification takes the following form:

$$
Y_{i t}=\alpha_{i}+\gamma_{t}+\sum_{\substack{s=-5 \\ s \neq-1}}^{S=8} \beta_{s} \text { Opioid }_{i} \times \mathbb{1}\left[s_{t}=t\right]+X_{i t} \lambda+\epsilon_{i t}
$$

For a given outcome $Y_{i t}, i$ indexes individuals and $t$ indexes calendar time in quarters. We let $s$ denote years relative to the onset of the heroin reduction in the fourth quarter of 2000. Our primary coefficients of interest are given by $\beta_{s}$. They come from the interaction of Opioid $_{i}$, which identifies individuals in the treatment group, with indicator variables for each event-time year. Since the onset of the heroin shortage occurred partway through the fourth quarter of 2000, we define event-time years before the event from the fourth quarter of one calendar year to the third quarter of the next (e.g., $s=-1$ from the fourth quarter of 1999 through the third quarter of 2000). After the event, event-time years follow calendar

years (e.g. $s=0$ for 2001, $s=1$ for 2002, etc.). We estimate coefficients for each of the four event-time years before the event and eight afterwards. The reference period is $s=-1$, the 12 months prior to the onset of the supply reduction.

We include individual fixed effects $\alpha_{i}$ and a vector of time controls $\gamma_{t}$ that consists of a complete set of event-year fixed effects; quarter-of-year fixed effects to account for seasonality; and a dummy variable for the partially treated fourth quarter of 2000 that is interacted with the treatment group indicator. We also include a vector of individual-level time-varying 
controls given by $X_{i t}$, which consists of a complete set of age fixed effects interacted with sex and Indigenous status indicator variables. ${ }^{19}$ These control nonparametrically for lifecycle trends related to drug use, drug treatment participation, criminal behavior and health that may vary by demographic characteristics. The error term is represented by $\epsilon_{i t}$, and we allow for an arbitrary correlation in errors over time at the individual level.

This approach relies on several key identifying assumptions. First, that the supply reduction was unanticipated and exogenous to the opioid users in our sample. The available evidence described in Section 2 suggests that the heroin reduction was unexpected and unrelated to local drug demand conditions. Second, that the time-varying unobserved determinants of our outcomes of interest affect opioid and non-opioid illicit drug users in similar ways (e.g., local policing activities or healthcare policies). These assumptions can be partially tested by using the pre-event time dummy variables to assess whether the trends in outcomes are similar across the treatment and comparison groups.

A third assumption is that the comparison group of non-opioid illicit drug users are not affected by the heroin supply reduction. This could be violated if the comparison group includes opioid users who never participate in opioid medication-assisted treatment, or if there are spillover effects of the heroin supply reduction that affect non-opioid drug users. We assess these concerns by using an event study specification without the comparison group:

$$
Y_{i t}=\alpha+\gamma_{t}+\sum_{\substack{s=-5 \\ s \neq-1}}^{S=8} \beta_{s} \mathbb{1}\left[s_{t}=t\right]+X_{i t} \lambda+\epsilon_{i t}
$$

The primary coefficients of interest remain $\beta_{s}$, which come from indicator variables for each event-time year preceding and following the event. The individual fixed effects are dropped, as event time and the age controls are now collinear at the individual level (Borusyak and Jaravel 2017). The vector of additional time controls, $\gamma_{t}$, now consists of quarter-of-year fixed effects and a dummy for the fourth quarter of 2000. The vector of controls, $X_{i t}$, now contains permanent measures of sex and Indigenous status interacted with a complete set of age fixed effects. Similar to equation (1), the error term is represented by $\epsilon_{i t}$ and we allow for an arbitrary correlation in errors over time at the individual level.

Together, the two event study approaches allow us to assess the role of different assumptions underpinning the estimates. We further assess robustness around these specifications and the composition of both the treatment and comparison samples after presenting and discussing our main results.

\footnotetext{
${ }^{19}$ For mortality outcomes, we also use permanent demographic controls instead of individual-fixed effects.
} 


\section{Data}

We create a new longitudinal dataset for this paper that links, at the individual level, administrative data held by the NSW Government from the criminal justice system, drug treatment programs and mortality records. NSW is unique among Australian states in having consistent individual-level criminal justice and treatment records since the early 1990s. This enables us to follow individuals several years either side of the onset of the heroin reduction, and over this period measure all arrests, all opioid medication-assisted treatment episodes, and all deaths in NSW.

The drug treatment data, from which we identify opioid users, comes from the NSW Department of Health's Pharmaceutical Drugs of Addiction System (PHDAS). The PHDAS records all individuals who have been prescribed opioid medication-assisted treatment in NSW since 1985. Methadone was the only opioid treatment prescribed before 2001, after which buprenorphine also began to be prescribed to a minority of participants. An entry to the database occurs when a medical physician is granted an "authority to dispense" methadone or buprenorphine to a particular individual. These authorities must be obtained for methadone or buprenorphine, as they are classified as drugs of addiction. ${ }^{20}$ Information in the PHDAS database includes: opioid treatment start and end dates; drug type and maximum dose authorized; and the reason for leaving the program.

The criminal offense data comes from the NSW Bureau of Crime Statistics and Research's Reoffending Database (Offence Level Data). It includes all individuals charged with a criminal offense in NSW since 1994, and includes information on offense types; date of occurrence; court outcomes; and demographic information, including sex, age and Indigenous status. Drug offenses include information on the class of drug involved (e.g., opioids, cocaine, amphetamines), but not subtypes of these drugs.

The Centre for Health Record Linkage extracted identifying information from these data sets on individuals with (i) opioid treatment episodes between 1985 and 2001 or (ii) arrests between 1994 and 2001 for a drug, property, or violent offense (i.e., nearly all offenses except for traffic and bail offenses). They then linked these individuals to more recent versions of these data sets, along with mortality and health data sets. ${ }^{21}$ One mortality data set is death registration data from the NSW Registry of Births Deaths and Marriages, which includes

${ }^{20}$ There are limited exceptions, such as hospital inpatients who receive schedule drugs for less than 14 days. See: https ://www.health.nsw.gov.au/pharmaceutical/doctors/Pages/Prescribe-S8-opioid.aspx.

${ }^{21}$ The Centre for Health Record Linkage is a sub-agency in the NSW Department of Health. They match individuals across data sets using names and the other available personal information. They expect that false negatives and false positives each occur at rates equal to around $0.5 \%$. See: https://www. cherel. org.au/structure-and-governance. 
information on individuals' date of death, age at death, sex and Indigenous status. The other is the Cause of Death Unit Record File, which includes cause-of-death information classified according to International Classification of Disease systems. Drug poisoning information allows us to identify deaths related to opioids, but not particular types of opioids. Both use information from death certificates, which are legally required and signed by physicians. We also have linked information from three other Department of Health data sets; however, they are not available before 2001 so are only used to check and fill in demographic information for our sample. ${ }^{22}$

Our combined data includes information on opioid treatment, criminal offenses, and mortality. We organize the data by: cleaning the opioid treatment episodes in line with previous research using these data (Burns et al. 2009) ${ }^{23}$ using cause-of-death codes to identify deaths that are related to opioids, the use of other types of drugs and alcohol, and other causes of death; ${ }^{24}$ and classifying criminal offenses as drug, violent and property offenses. ${ }^{25}$ The panel starts in

${ }^{22}$ The Admitted Patient Data Collection records information on inpatient admissions to public hospitals; the Emergency Department Data Collection records information on emergency room visits of public hospitals; and the Ambulatory Mental Health Data Collection records information on participants in mental health programs, including psychiatric outpatients and outreach services. The first two data sets begin in 2005, and the third begins in 2001. For more information on these and the other health data sets, see: https://www.cherel.org.au/data-dictionaries\#section1.

${ }^{23}$ The PHDAS records transfers from one provider to another as exits, such as when someone moves from receiving methadone at a treatment clinic to a community pharmacy. Similar to Bell et al. (2009), we ignore these, defined as when the treatment gap is $\leq 7$ days and when it is a transfer (i.e., "reason patient ended program" codes 26 to 34 ). We also remove episodes related to a buprenorphine trial (90 episodes) and data cleanup (520 episodes).

${ }^{24}$ Deaths after 1997 are coded using the International Classification of Diseases, Tenth Revision (ICD-10). The Australian Bureau of Statistics (2002) define drug-induced deaths if they have an ICD-10 underlying cause of death related to drug overdose (X40-X44, X60-64, X85, Y10-Y14) or mental/behavioral disorders linked to drug abuse, which for opioids is either opioid abuse (F11) or the abuse of multiple drugs (F19). We define opioid-related deaths as deaths with one of those codes and a drug identification code specifying that opioids were found in the decedent's system (T40.-T40.4). We also found that that the underlying cause R99 (Ill-defined and unknown cause of mortality) was sometimes paired with the opioid drug identification codes, and therefore also included those deaths as opioid-related. For comparison, this definition is similar to how the US CDC define opioid drug overdoses (Ahmad et al. 2020). Deaths prior to 1997 are coded according to ICD-9. We classify opioid-related deaths using crosswalk codes included in the Australian Bureau of Statistics (2002), and choose the sub-codes focused on opioids or polydrug use: 304.0, 304.6, 304.9, 305.5, E850.0, E850.2, E853.2, E854.0, E854.0, E854.1, E858.9, and E980.0. We define drug- and alcohol-related deaths using ICD-9 and ICD-10 codes from Evans and Moore (2011), who create a list from studies of substance abuse in Australia and the US (see their appendix for the full set of codes).

${ }^{25}$ Offenses are defined in terms of Australian and New Zealand Standard Offence Classification (ANZSOC) system (Australian Bureau of Statistics, 2011). We define offense groups (ANZSOC codes) as: (i) illicit drug offenses (1011-1042): drug possession/use (1022,1041,1042); drug supply/distribution (1011,1012,1031,1032); (ii) violent offenses (100-699 except 610-619): homicide (111); manslaughter/attempted homicide $(121,131)$; driving causing death (132); assault and other acts to cause injury (211-299), including serious assault with injury (211), serious assault with no injury (212), and common assault (213); sexual assault and related offenses (311-329); driving under the influence of alcohol and other drugs (411); harassment and threatening behavior (531-532); (iii) property offenses (611-612 plus 700-999): robbery (611-612); burglary/break and 
1994, which is when offending data are first available, and ends in 2008.

We use a longitudinal panel that tracks individuals on a quarterly basis. To estimate the response to the heroin supply reduction among opioid users, we identify 27,467 individuals who participated in opioid medication-assisted treatment at some point between 1985 and September 2000 (i.e., before the onset of the heroin supply reduction). They enter the panel in the quarter of their first opioid treatment episode (or in January 1994 if already in opioid treatment), and remain through to their death or the end of 2008. Our comparison group consists of 25,584 individuals who have a charge for non-opioid illicit drug possession or use between 1994 and September 2000, but do not have any opioid-related charge or opioid treatment admission over the entire period. They enter the panel in the quarter of their first non-opioid illicit drug offense and remain through to their death or the end of 2008. Later in the paper, we assess the robustness of our estimates to different sample selection criteria.

Summary statistics are presented in Table 1. These are calculated over the five years prior to the heroin supply reduction (i.e., from the fourth quarter of 1995 through the third quarter of 2000), and incidence rates are scaled to an annual basis and per 1,000 individuals. The means for our treatment group of opioid users are shown in column (1). The average age is 33.8 years, and $30 \%$ are females. Mortality averages 9.49 deaths each year per 1,000 individuals, and approximately $60 \%$ of these deaths are directly related to opioids. This mortality rate is around seven times higher than the mortality rate at similar ages in the general population (Australian Bureau of Statistics 2001). The most common illicit drug charge is for opioid use/possession, which averages 41 offenses each year per 1,000 individuals. Opioid supply/distribution offenses are rare; the annual average is 0.2 per 1,000 individuals. The rate of non-opioid use/possession offenses is about $80 \%$ smaller than the rate for opioid use/possession charges; around $60 \%$ of these are for methamphetamine and $25 \%$ for cocaine. There is an average of 78 violent offenses each year per 1,000 individuals, with the majority for assault. The annual average for property offenses is 341 per 1,000 individuals. Non-motorvehicle theft accounts for approximately $70 \%$ of these offenses, while burglary accounts for $11 \%$ and motor vehicle theft accounts for $7.5 \%$.

The pre-event means for the comparison sample are shown in column (2) of Table 1. They are on average 3.6 years younger and $13 \%$ are female, which is much lower than the $30 \%$ for the opioid-user sample. In terms of illicit drug offending, the treatment and comparison group exhibit similar rates of non-opioid drug use/possession charges, with a relatively higher

enter (711); motor vehicle theft (811- 812); other theft (821-841); and fraud, deception and related offenses (911-999). These classifications encompass nearly all offenses, with those omitted primarily being traffic and bail offenses. 
fraction of charges for methamphetamines and a lower one for cocaine. In terms of other offenses, the comparison group has slightly higher average rates of violent offenses and much lower rates of property offenses. Our specifications will allow us to examine the pre-event trends across the treatment and comparison samples, which we discuss as part of our results in Section 5.

We use aggregate data to assess what fraction of NSW opioid-related outcomes are accounted for by our sample. This is shown in Figure A7 in the appendix. Between 1996 and 2000, our sample accounts for around 40-50\% of opioid-related deaths, 40-45\% of opioid use/possession offenses, and $5-10 \%$ of opioid supply/distribution offenses. ${ }^{26}$ The fractions are quite consistent throughout the pre-event period; we consider the changes in coverage after the supply reduction when we turn to interpreting our results in Section 5.

\section{Results}

Our data allow us to estimate the impact of the heroin supply reduction on many different outcomes. We organize the discussion of our results as follows. We examine outcomes related to opioid use in Section 5.1, and substitution to other drugs in Section 5.2. We examine broader mortality changes in Section 5.3, and the impact on property and violent crime in Section 5.4. We examine effect heterogeneity in Section 5.5, robustness to specification choices and sample-inclusion criteria in Section 5.6, and the broader impacts of the supply reduction in Section 5.7.

\subsection{Opioid-related outcomes}

We initially examine the effects of the reduction in heroin supply on opioid-related outcomes by examining patterns in opioid-related causes of death and criminal charges using plots of raw data. The left column of Figure 2 shows the raw trends from 1995 to 2008, illustrating a dramatic decline from late 2000 in outcomes related to opioid use. With respect to opioidrelated mortality, there are around six deaths per 1,000 opioid users each year prior to the heroin supply reduction, a rate approximately 100 times larger than the population-level rates depicted in Figure 1. A visually clear reduction in opioid-related deaths occurs late in 2000, when the mortality rate halves and remains low, averaging around 2.5 deaths annually per 1,000 individuals thereafter. A similar drop occurs for opioid possession/use offenses, where there are approximately 40 arrests per 1,000 individuals in our treatment group each year prior to the supply reduction and fewer than 15 arrests per 1,000 individuals each year

\footnotetext{
${ }^{26}$ Note that we only measure outcomes for our sample after their first opioid treatment episode; the fraction of offenses is slightly higher if we consider offenses occurring prior to their opioid treatment.
} 
after it.

For each of these outcomes, we present estimates from our primary event-study specification described by equation (1). We plot the estimates for each lead and lag year in the right column of Figure 2 and summarize them in Table 2 by averaging the coefficients over four time periods: (i) four pre-reduction years (years -5 to -2 ); (ii) the first post-reduction year (year 0); (iii) the second post-reduction year (year 1); and (iv) longer-term effects over the remaining six years (years 2 to 7 ). Overall, these estimates mirror the patterns in the raw data described above. Most importantly, with one exception discussed below, we do not find significant changes in these outcomes in years prior to the supply reduction, a pattern that alleviates concerns about misattributing pre-existing trends in these outcomes to the impact of the reduction in heroin supply. In contrast, estimates for most years following this event are statistically different from zero. As shown in the first row of Panel A in Table 2, the opioid-related mortality rate decreases by 2.02 deaths per 1,000 individuals in the first year, a decline of nearly $40 \%$ relative to the reference-period mean. This grows to a $60 \%$ decline in the longer-term period. Similarly, other results in Panel A of Table 2 imply persistent decreases in criminal charges for opioid use/possession that are on the order of 50-60\% relative to the reference-period mean. All of these estimates are statistically significant at the $1 \%$ level.

For opioid use/possession charges, Figure $2 \mathrm{~d}$ shows that there are two pre-event year coefficients with significantly higher rates than the reference period. The raw data in Figure 2c suggests that these are primarily due to higher opioid possession charges in late 1998 and early 1999, which is just after the introduction of new police powers that made it easier for police to search individuals in public places and facilitated crackdowns in heroin street markets. ${ }^{27} \mathrm{We}$ re-estimate the event study specification without opioid possession charges processed at the courthouses closest to the two major street markets, which account for approximately half of the opioid use/possession offenses in NSW. ${ }^{28}$ The pre-event estimates, shown in Figure $2 f$ and the third row of Panel A in Table 2, are now small and not statistically different from the reference period. After the supply reduction, there are still visually clear and statistically significant reductions in opioid use/possession charges that are qualitatively similar to those shown for all areas. The scale of the estimates with and without the main heroin street markets are similar, which suggests earlier crackdowns did not affect the broader response to the heroin supply reduction. Moreover, we show in subsequent analyses that the pre-trends

\footnotetext{
${ }^{27}$ As discussed in Section 2, NSW Police got new powers in July 1998 allowing them to move people on or search them when suspected of having weapons. Around this time, there were occasional crackdowns in heroin street markets in Cabramatta and Central Sydney/Kings Cross (Maher and Dixon 2001, Degenhardt et al. 2004).

${ }^{28}$ The courthouses we remove are Fairfield, Liverpool, Sydney Downing Centre, Central and Redfern.
} 
present here are generally not there for other outcomes, which suggests that crackdowns primarily affected opioid use/possession offenses rather than a broader range of outcomes related to opioid use.

We also examine whether there are changes in offense rates for distributing or selling opioids. This outcome is rare, with 0.31 offenses per 1,000 individuals in the year prior to the supply reduction. We find an increase in the second year afterwards of 0.46 opioid supply offenses per 1,000 individuals as reported in the fourth row in Panel A of Table 2, or a 150\% increase relative to the reference period. This increase dissipates in the longer-term but remains marginally significant. This pattern is consistent with different, riskier opportunities after sophisticated heroin suppliers exited Australia, as described in Section 2. If we consider the net changes in opioid offenses, the decrease in the opioid possession charges is far larger than the increase in opioid distribution offenses.

As discussed in Section 4, individuals enter our treatment group when they begin opioid medication-assisted treatment. We also evaluate the rate at which individuals exit opioid treatment and whether it changes after the heroin supply reduction. Event-study estimates presented in Appendix Table A3 imply a 20-30\% decline in opioid treatment dropout rate and an over $50 \%$ increase in successful completion rates after the heroin supply reduction. Opioid users are more likely to remain in drug treatment following the reduction in heroin supply and, for those that do stop taking methadone, they are more likely to do so when a physician determines that treatment is no longer necessary.

\section{$5.2 \quad$ Other drug-related outcomes}

We next consider the effect of the heroin supply reduction on outcomes related to non-opioid drugs, including alcohol. We examine two types of outcomes: mortality associated with non-opioid drug use and non-opioid drug offenses. It is not possible to link individuals in our sample to drug treatment information for non-opioid drugs, as the NSW Government collects such information only for opioid medication-assisted treatment (as it uses addictive drugs). We use the primary event study specification with the comparison group, given by equation (1), to account for underlying changes in drug markets or relevant policies. Overall, we find evidence that our sample of opioid users substitute towards other drugs following the heroin supply reduction.

We first estimate changes in mortality where the primary cause of death is related to nonopioid drug use, including alcohol. As shown in Figure 3a, the pre-reduction annual coefficients are close to zero, indicating no pre-existing differences in trends between the treatment and comparison groups. After the heroin supply reduction, the event study coefficients are positive 
and steadily increasing in magnitude for the first six years, before decreasing in the seventh and eighth years. These effects are summarized in the first row of Panel B in Table 2, where the average estimated increase for the last six years is 0.29 deaths per 1,000 individuals, or $180 \%$ relative to the reference period. These results indicate some substitution from opioids to other drugs, and partially offset the large declines in opioid-related mortality discussed in Section 5.1. However, these effects are less than one-tenth the size of the opioid-related mortality decline.

Opioid use has higher mortality risks than most substitutes, so the relative changes in mortality are not necessarily proportional to underlying drug use. As another measure, we use charges for using or possessing non-opioid illicit drugs, which are mostly for amphetamines and cocaine. ${ }^{29}$ Figure $3 \mathrm{~b}$ shows that opioid users' relative offending rates for non-opioid illicit drug use/possession are flat prior to the heroin supply reduction. Immediately after its onset, there is a visually clear and statistically significant increase in non-opioid drug use offenses. While the largest increase occurs in the first year, non-opioid drug offenses are elevated throughout. We quantify these effects in the second row of Panel B of Table 2. After the supply reduction, non-opioid drug offenses increase by 6.54 offenses per 1,000 individuals in the first year, 3.98 offenses in the second year, and by an average of 4.43 offenses over the subsequent six years. The estimates imply that, relative to the year before the supply reduction, non-opioid drug use was $76 \%$ higher in the first year and approximately $50 \%$ higher after that.

In order to understand if these patterns differ by drug type, we show the results for methamphetamine and cocaine offenses in Figures $3 \mathrm{c}$ and $3 \mathrm{~d}$ and in the third and fourth rows of Panel B of Table 2. Both drugs contribute fairly equally to the increase in non-opioid charges in the first year after the supply reduction. The longer-term increases are entirely due to higher amphetamine offense rates, as cocaine offenses quickly revert to baseline levels.

We also examine whether there are changes in offenses for selling non-opioid illicit drugs. This is a rare outcome: in our treatment group, there were only 0.16 of these offenses per 1,000 individuals in the reference year. The results in Figure 3e and the fifth row of Panel B in Table 2 show no difference in this outcome, suggesting that opioid users in our sample did not respond to the heroin supply reduction by selling more non-opioid illicit drugs.

To assess whether the alcohol use of opioid users was affected by the heroin supply reduction,

\footnotetext{
${ }^{29}$ Amphetamines and cocaine account for $90 \%$ of non-opioid offenses; others include ecstasy, barbiturates, and hallucinogens. We do not include marijuana, as from 2000 police could issue cautions and these are not in our data. See: https://www.police.nsw.gov.au/crime/drugs_and_alcohol/drugs/drug_pages/drug_ programs_and_initiatives.
} 
we examine offense rates for driving under the influence of alcohol and other drugs. In practice, this represents driving under the influence of alcohol, as the only roadside testing was for alcohol at the time of the heroin supply reduction. ${ }^{30}$ This is the only consistent measure of alcohol use in our data. Figure $3 f$ shows the event-study estimates for this outcome. There is no change in driving under the influence in the first year after the supply reduction, but a steady decline thereafter that becomes statistically significant over time. The longer-term decline, summarized in the sixth row of Panel B of Table 2, represents a $27 \%$ decline relative to the reference period. As a more general measure of changes in alcohol or drug-affected driving, we consider whether there is a change in offense rates for driving causing death. The results in Figure $3 \mathrm{~g}$ and the final row of Panel B in Table 2 show no change in this outcome after the supply reduction. Overall, these results suggest that opioids and alcohol may be complements, at least for those who choose to drive under the influence of alcohol, but that these effects are not large enough to affect the likelihood of fatal traffic accidents for which opioid users in our sample were deemed responsible.

Our results are consistent across the health and criminal justice domains. The rapid reduction in heroin supply led opioid users to substitute to other illicit drugs: temporarily for cocaine, and more permanently for amphetamines. This substitution shows up in causes of death associated with non-opioid drugs, although it takes several years for this to occur at statistically significant levels. There is no change in the likelihood of supplying non-opioid drugs. There is a reduction in the rate at which opioid users drive under the influence of alcohol, but no apparent change in the likelihood driving in a way that causes the death of other road users.

\subsection{Overall mortality}

We now evaluate the impact on overall mortality rates. The mortality effects already presented are mixed: deaths related to opioid use declined after heroin supply fell, while there was an increase in deaths related to using other drugs and alcohol. Given that there may have been further changes to other causes of death, it is important to consider the overall impact.

We summarize mortality estimates based on equation (1) in Panel C of Table 2 and present annual event-study estimates for all-cause mortality in Figure 4a. The results for overall mortality in the first row of Panel $\mathrm{C}$ in Table 2 show similar pre-event trends between the treatment and comparison groups. In the first two years after the heroin supply reduction, mortality drops by -1.83 and -2.03 deaths per 1,000 individuals, respectively. For the subsequent six years, we find an average of -2.63 deaths per 1,000 individuals relative to the reference period. All of these post-reduction estimates are statistically significant at the $5 \%$ level or

\footnotetext{
${ }^{30}$ Alcohol breath testing was used throughout our sample period. Breath testing for other drugs was introduced
} in 2007. Blood testing for other drugs, while possible prior to 2007, was rare (Quilter and McNamara 2017). 
less. They imply relative declines in overall mortality of around $20 \%$ in the short term and $30 \%$ in the longer term.

When compared to the estimated reduction in opioid-related deaths, presented in the first row of Panel A of Table 2, the point estimate for the effect on overall mortality in the first year is $83 \%$ the size of the equivalent opioid-related estimate. This implies that nearly all of the lives saved through averted opioid deaths in the first year after the supply reduction translated into overall gains. In the longer term, this ratio is $77 \%$, implying that non-opioid causes of death grew over time and offset around one quarter of the longer-term reduction in opioid-related deaths.

We previously discussed estimates of other drug- and alcohol-related causes of death presented in the first row of Panel B in Table 2. We also estimate effects for all other causes in the final row of Panel $\mathrm{C}$ in Table 2 (i.e., deaths not directly related to drugs or alcohol). Across these results, the only statistically significant estimate - at the $5 \%$ level - is the estimated increase in other drug- and alcohol-related deaths in the last six years of the sample period. However, all of the post-reduction coefficients for other causes of death are positive and sometimes larger than those for causes related to other drugs and alcohol. It is therefore possible that the offsetting increase in non-opioid deaths may have come from a combination of causes related to drug and alcohol use as well as a broader set of competing risks.

\subsection{Other criminal activity}

We next consider the impact on more general types of criminal offending, focusing on violent and property crime. All of the results are estimated using equation (1). We first present results for all of these offenses, with the annual event-study estimates shown in Figure 4b. Pre-reduction offending rates are flat, suggesting that any trend in overall offending rates is similar across the treatment and comparison groups. In the first year after the onset of the heroin supply reduction, there is a visually clear and statistically significant increase in offense rates. Offense rates then sharply decline, with statistically significant decreases from the second year after the supply reduction. By the eighth year, the estimated change is on the order of -300 offenses per 1,000 individuals, or roughly two thirds of the reference-period mean.

These overall effects mask striking differences between the results for violent and property crime, as shown in the second two rows of Panel D in Table 2. In the first year after the heroin supply reduction, there is a statistically significant increase in violent offenses of around $30 \%$. The effect more than halves in the second year, and returns to pre-reduction levels after that. In contrast, estimates for property offenses are not statistically different from zero in the first 
year, after which they are negative, statistically significant, and increasing in magnitude. Over the last six years, we find an average annual decline of -199 offenses per 1,000 individuals in the treatment group, which is a $54 \%$ decline relative to the reference period. The short-term increase in the sum of violent and property offenses that was apparent in Figure $4 \mathrm{~b}$ is almost entirely driven by violent offending, while the longer-term decrease is driven by a decline in property offenses.

Since different types of crime vary substantially in terms of severity, we further investigate changes by offense subcategories and summarize these results in Figure 5 and Appendix Tables A1 and A2. Focusing first on specific types of violent crime, we find large increases in murder and assault immediately following the reduction in heroin supply. The increase in homicide depicted in Figure 5a equates to an increase of $724 \%$ relative to the year prior to the supply reduction. To put this increase in context, individuals in the treatment group were charged with three murders in the year prior to the supply reduction and 23 in the first post-reduction year, accounting for $20 \%$ of the statewide total in 2001. Beyond this initial increase, estimates are small and suggest that homicide rates return to baseline levels.

Assaults are the most common violent offenses in our treatment group, accounting for $73 \%$ of the violent offenses in the year prior to the supply reduction. Figure $5 \mathrm{~b}$ shows that there is a clear increase in assault charges immediately after the supply reduction, as well as some persistence beyond the first year. Assaults increase by an estimated 21.6 offenses per 1,000 individuals in the first year, 10.3 offenses in the second year, and 9.1 offenses in the final six years of the sample period (see Table A1, column (4)). All of these estimates are statistically significant at least at the $5 \%$ level. Relative to the reference period, the point estimates imply assaults increase by $35 \%$ in the first year and around $15 \%$ in the longer term. Further results indicate that the largest increases occur for the most severe category of assaults: serious assaults resulting in injury, as shown in column (5) of Table A1. ${ }^{31}$

For sexual assault, there is no detectable change in the first two years after the supply reduction, and a statistically significant longer-term reduction of 1.1 annual offenses per 1,000 individuals (see Table A1, column (8)). There are no statistically significant changes after the supply reduction for charges for manslaughter/attempted homicide or for harassment. ${ }^{32}$

${ }^{31}$ The estimates for serious assault resulting in injury are statistically significant at the $1 \%$ level and imply increases of $67 \%$ in the first year and around $50 \%$ in the longer term. Serious assaults not resulting in injury do not change. Common assault, which covers less serious assaults, increases at statistically significant levels, implying increases of $44 \%$ in the first year and around $20 \%$ in the longer term. For the latter two categories, there are statistically significant pre-shortage trends due to the differences between the treatment and control groups five years prior to the supply reduction. If this year is dropped, the pre-trend estimates are small and no longer statistically significant.

${ }^{32}$ Sexual assault charges include those for rape, attempted rape, indecent assault and threats to commit 
We also consider specific types of property offenses in Figure 5 panels (e) through (h) and Appendix Table A2. While robberies are often considered a violent offense, we group these charges with property crimes given the pecuniary incentives involved and their importance to many heavy drug users who need to obtain cash to buy drugs. ${ }^{33}$ There are large and persistent increases in robberies after the heroin supply reduction, as shown in Figure 5e. As Table A2 column (2) shows, our results indicate estimated increases of 8.24 robberies per 1,000 individuals in the first year, 5.23 robberies in the second year, and an average of 3.86 robberies per year in the final six years. All of these estimates are statistically significant at the $1 \%$ level. Relative to the reference period, robberies increase by approximately $350 \%$ in the first year and $150 \%$ in the longer term. Burglary offenses (where perpetrators break into and enter houses, businesses or other premises unlawfully) also increase immediately after the supply reduction, by around $30 \%$ relative to pre-reduction rates (see Table A2 column (3)). However, unlike charges for robbery, burglary offenses decline in the long term and are on average $37 \%$ lower than pre-reduction levels in the final six years of the sample period. We find a similar pattern for another serious category of property crime, motor vehicle thefts, as that for burglaries: a short-term increase is followed by a long-term decline, as shown in Figure $5 \mathrm{~g}$. Finally, the most common category of property crime, theft, declines throughout the period following the heroin reduction supply. These are the most frequent types of property offenses within the treatment group, averaging 245 offenses per 1,000 individuals in the baseline period. In the final six years of the sample period, offense rates for theft are more than $60 \%$ lower than in the reference period.

In summary, we find substantial increases in criminal charges for serious violent crimes (homicide and assault) as well as for serious property crimes (robbery, burglary and motor vehicle theft) associated with the reduction in heroin supply. These results may, at least partially, be driven by substitution towards drugs more closely connected to violent or impulsive behavior than opioids, like amphetamines and cocaine. Most of these effects dissipate over the longer term, but assault and robbery charges remain at elevated levels throughout the eight years following the heroin supply reduction. The short- and long-term declines in theft among our opioid-user treatment group is consistent with this type of criminal activity supporting heroin purchases. As we discuss in the conclusion, the effects we observe for our treatment group of opioid users help to explain the dramatic decline in property crime in NSW since 2001.

sexual assault. Harassment includes charges for offenses encompassing actions that harass or are intended to harass, threaten or invade the privacy of an individual, but not amounting to an assault or other more serious offense.

${ }^{33}$ This choice does not really affect results in Table 2 , as robbery represented $0.3 \%$ of all offenses in the reference year. 


\subsection{Heterogeneous effects by different types of opioid users}

We next consider how the results differ by the demographic and other characteristics of our sample. To do this, we estimate specifications where we interact the event-time dummies with the characteristics. For ease of exposition, we present estimates only for two key parameters of interest in Table 5: the immediate effects in the first year of the supply reduction (year 0); and the longer-term effects averaged over the last six years (years 2 to 7 ). We test for the equality of coefficients across different groups and present the p-values for these tests.

Results for males and females are presented in Panel A of Table 3. We find larger declines in mortality for females in the first year following the supply reduction, but larger long-term decreases for males. Both the short-term increase in violent offending and the substitution toward non-opioid drugs appear to be driven by males, although the only statistically significant difference in the male and female coefficients is for first-year violent offenses. We also observe a statistically significant difference between males and females in terms of the change in

longer-term property offenses: males have a larger estimated decrease, although this difference is consistent with the sex-specific declines being similar relative to their pre-event means.

We also split the sample by the median age at the time of the supply reduction, 32 years, and present the results in Panel B of Table 3. The mortality results are similar across younger and older individuals. For the other outcomes, we see larger estimates for younger individuals. However, the patterns are more similar when the estimates are scaled by the reference-period means, implying that younger and older opioid users had fairly similar relative responses.

Finally, we evaluate whether effects differ by the intensity of opioid treatment prior to the reduction in heroin supply. We create a variable indicating whether individuals in our treatment group had a maximum methadone dose above the median of $150 \mathrm{mg}$ per day, and interact this variable with the post-reduction event-time variables. Higher doses of methadone indicate a greater tolerance to opioids. The mortality reductions occur in the lower-dose group, while the higher-dose group had higher rates of drug substitution throughout and higher violent offending rates in the first year after the heroin supply reduction. Together, these patterns suggest that the improvements in health and crime occurred predominantly among those with lower opioid use.

\subsection{Robustness of results to alternative specifications and sample definitions}

We assess the sensitivity of our results to our choice of specification and sample restrictions. We present these results in Figure 6 and across several figures and tables in the appendix. Overall, the results presented above are consistent across alternative specifications and varying definitions of our treatment and comparison groups. 
First, to assess the role of the comparison group, we present results with and without it in Figure 6, as well as in the second and third columns of Appendix Table A5. Estimates without the comparison group come from equation (2). Overall, we find very similar results across both specifications, with two notable differences. First, the increase in charges for methamphetamine use/possession is less persistent in the specification without the comparison group. This suggests that methamphetamine use returns to pre-reduction levels for our group of opioid users shortly after the supply of heroin was reduced, but that methamphetamine use declines even further for our comparison group during these years. Second, without the comparison group, there is a short-term increase in property offenses and the magnitude of the long-term decline becomes smaller. However, we also find a significant pre-trend in this outcome when not using the comparison group, suggesting that there are underlying changes in property crime rates throughout this period (e.g. the importance of declining prices of consumer goods as recently shown by Draca, Koutmeridis and Machin 2019). We also find a statistically significant pre-trends for violent offenses, although these do not affect the estimated effects after the onset of the supply reduction. Overall, the patterns in Figure 6 and Appendix Table A5 ameliorate concerns that our results may be attenuated by having opioid users in the comparison group, or by spillovers affecting non-opioid illicit drug markets. Next, we assess robustness of our results, focusing on four key outcome variables: overall mortality, non-opioid drug possession, violent offending, and property offending. First, we modify our difference-in-differences specification by sequentially changing the control variables. The results are presented in Appendix Table A4. In column (1), we start with results from a specification with no fixed effects or other covariates. Overall, results from this parsimonious specification are similar to those with more detailed controls, except that property offending has a pre-trend and a smaller long-term decline. Once we control for fixed individual-level characteristics in column (2) and age in column (3), which is equivalent to equation (1), we see no statistically significant pre-trend and a larger long-term impact of the supply reduction on property offending. In column (4), we replace pre-event year indicators with a linear trend to allow for a pre-existing trend in outcomes. The results are similar to those in column (3), which is not surprising given there are relatively constant pre-event differences in outcomes across the treatment and comparison groups. The only noteworthy difference is a larger long-term increase in violent offending, although we cannot reject a null hypothesis that the relevant coefficients in columns (3) and (4) are equal. Finally, to assess whether time-varying economic conditions have a differential impact on the treatment and comparison groups, we present results that include controls for quarterly unemployment rates interacted with treatment group status in column (5). Overall, these results are consistent with those from our preferred specification in column (3). 
We assess the impact of expanding the comparison group to include anyone with a property or violent offense in the pre-event period (subject to not receiving opioid treatment or having an opioid-related criminal charge). This comparison group has 134,219 individuals, or more than five times the size of the original one. The results, presented in column (4) of Appendix Table A5, have a couple of notable differences. First, the decline in mortality after the supply reduction is smaller than when using the drug-offender comparison group (or no comparison group at all). Second, we observe a statistically significant difference across the treatment and comparison groups in their pre-event trends in violent offending. While most results are consistent, our primary comparison group of non-opioid drug offenders is more similar to our treatment group in terms of pre-event trends.

We next assess whether our results could be influenced by sample attrition due to differential migration or mortality across our treatment and comparison groups. To do so, we restrict our sample to individuals observed as alive and resident in NSW in the post-reduction period in any of our administrative datasets (including the healthcare data described in footnote 20). These results, presented in column (5) of Appendix Table A5, are qualitatively similar to our main estimates.

Finally, we estimate effects for two alternative definitions of our opioid-user treatment group in Appendix Table A6. First, we estimate effects for the subsample of our primary treatment group who have a criminal charge during the period prior to the heroin supply reduction. Among this group, we observe similar declines in mortality but effects that are greater in magnitude for criminal offenses. This is not surprising, given that the baseline offending rates are also substantially higher for this subsample. Next, we construct a group of opioid users using the criminal offense data instead of the medication-assisted treatment data. We include individuals with a opioid-related drug charge prior to the supply reduction. This group experiences qualitatively similar changes in violent and property crime offenses that are also larger in magnitude, but again this may be due to their relatively high baseline offending rates. Their mortality response implies a slightly larger own-price elasticity of demand, which may be due to this sample including individuals who are less addicted to opioids, as some had not participated in medication-assisted treatment.

\subsection{Evidence of broader changes in drug use and crime}

Our estimates imply substantial short- and long-term changes in criminal activity among a group that account for around 40-50\% of all opioid-related deaths and drug arrests in NSW in the years before the heroin supply reduction. We now evaluate the influence of the estimated changes in our sample on aggregate crime trends in NSW. 
Using the full set of criminal charges in NSW, we calculate a counterfactual number of charges per 10,000 individuals in NSW without the heroin supply reduction effects on our sample by adding or subtracting the changes implied by our estimates. For example, in the fourth year after the supply reduction, we find a reduction of around 200 property offenses per 1,000 opioid users (see Figure 6b). Scaling this estimate by the 27,487 opioid users in our sample $(-200 \times 27.487)$ implies approximately 5500 more charges for property offenses than observed in 2004.

The actual and counterfactual aggregate violent crime rates are shown in Figure A8a. Our estimates imply a small increase in aggregate violent offenses in 2001, the first year after the supply reduction, but no measurable longer-term impacts. Moreover, there are no discernible changes in the underlying trend in violent offenses, suggesting that responses to the heroin supply reduction beyond our sample had little impact on aggregate levels of violent crime.

The actual and counterfactual aggregate property crime rates are shown in Figure A8b. The impact of the heroin supply reduction on our sample of opioid users had a sizeable influence on long-term property crime rates, explaining around two-thirds of the decline in property crime in NSW from 2001 to 2008. ${ }^{34}$ Property crime peaked in 2001, and these results suggest that opioid users account for much of the drop in property crime thereafter.

\section{Conclusion}

We provide new insights into the response to opioid users of a long-term reduction in heroin supply. We estimate meaningful changes in their mortality, drug substitution behavior and criminal offending. Three features help us to develop more precise estimates of the impact of an illicit drug supply shock than have been possible in other settings. First, the reduction in supply is large and long-lasting relative to most shocks that have been examined. Second, widespread and inexpensive access to addiction treatment and good record-keeping within that system enable us to identify opioid users who account for nearly half of opioid-related deaths in NSW. This is remarkable given the challenges inherent in studying illicit markets. Third, we follow opioid users for several years. This allows us to understand both immediate and the longer-term effects after opioid users have adapted to heroin being more expensive and less widely available.

There are several key findings. In terms of outcomes directly linked to illicit drugs, we find large and persistent reductions in opioid-related mortality and offenses that are partly offset by substitution to non-opioid illicit drugs. Substitution to amphetamines and cocaine occurs

\footnotetext{
${ }^{34}$ Property offenses fell by $17 \%$ from 2001 to 2008 ; if our estimated effects are excluded, the decline is $5.3 \%$.
} 
in the first year, with amphetamine use staying elevated thereafter. This substitution increases non-opioid drug deaths, which together with other competing mortality risks offset around $20 \%$ of the reduction in opioid-related deaths. Offense rates increase in the first year of the supply reduction, then decline throughout the rest of the sample period. Violent offenses account for most of the initial increase, while property offenses account for most of the longer-term decline. Our findings demonstrate that is it important to assess supply-side interventions over several years, as the immediate effects may not reflect the direction or magnitude of longer-term responses.

The effects vary across outcomes and over time, so we aggregate them by estimating a net present value at the start of the heroin supply reduction. Lives are valued using Australian estimates of the statistical value of life (Viscusi 2018). We value crime costs using Australian Institute of Criminology reports, which include estimates of the extent of under-reporting to police (Mayhew 2003, Smith et al. 2014). We combine this information with annual point estimates from our main specification, use a $2 \%$ discount rate, and scale the estimates to 2019 dollars. No value is attributed to drug-defined crimes, such as drug use/possession offenses. More details and references are provided in the appendix.

On this basis, we calculate that there are net savings in each of the eight years after the heroin supply reduction and the net present value is approximately A $\$ 4.97$ billion (US $\$ 3.53$ billion). However, if we incorporate higher estimates of violent-crime victimization costs in Australia from Johnston, Shields and Suziedelyte (2018), the net value in the first year after the heroin supply reduction changes from to a net saving of $\mathrm{A} \$ 268$ million to a net cost of $\mathrm{A} \$ 244$ million. The value of outcomes in the other years change very little, as the violent-crime effects are concentrated in the first year. With these higher victimization costs, the net present value is around A $\$ 3.74$ billion (US $\$ 2.66$ billion), or $16 \%$ lower than before. This represents an average net saving of around $\mathrm{A} \$ 136,000$ (US\$97,000) per individual opioid user in our sample.

These calculations show that the heroin supply reduction had mixed effects on mortality and crime immediately after its onset. These may represent net savings or costs, depending on how different outcomes are valued. The valuation of different outcomes further emphasizes that, in the longer term, the heroin supply reduction produced substantial benefits in terms of increasing life expectancy and reducing crime. ${ }^{35}$ Given that our sample accounts for less than half of opioid-related deaths in NSW and around one-eighth of opioid-related deaths in

\footnotetext{
${ }^{35}$ The values needed to generate net present values close to zero are highly unlikely. For example, violent crime costs would have to increase by a further $\mathrm{A} \$ 0.5$ million per crime - or five times the cost with the higher victim costs from Johnston, Shields and Suziedelyte (2018) included - without any corresponding increase in the value of other outcomes. Estimates based on confidence interval bounds and higher discount rates still produce large savings when evaluated over the fulleight years.
} 
Australia in the late 1990s, the results suggest that the reduction in heroin supply may have delivered tens of billions of dollars in savings by lowering deaths and crime rates.

There are several limitations to the analysis. First, the administrative data do not allow us to gain a full understanding of the responses and outcomes of opioid users in our sample. We have only coarse measures of drug use, addiction and health, and we do not know what is happening to their employment, income or family relationships. While reduced mortality and lower crime are generally correlated with improvements in other outcomes, we cannot assess the full welfare implications of the reduction in heroin supply for our sample. Second, we are missing opioid users who do not engage with the treatment system. We expect them to generally have similar responses in terms of drug consumption, criminal activity and mortality outcomes. However, it is difficult to precisely assess the overall effects of the heroin supply reduction, even in terms of mortality and criminal activity. Third, the heroin market disruption in Australia could have affected other countries, such as increasing heroin supply to other markets. Such changes have not been detected, but could affect the overall impacts on mortality and crime.

There are also limitations in terms of external validity. Heroin was the main opioid consumed in Australia in the early 2000s, and fewer opioids were available than are generally available in most countries now. It is also the case that the "harder" illicit drugs were more expensive than heroin prior to the supply reduction, implying that the substitution possibilities may have been more limited than if there were cheaper options available. That said, many illicit drug epidemics appear to occur because a particular drug delivers a much cheaper "high" than has previously been available: heroin and fentanyl in the current opioid crisis and crack cocaine previously, were much cheaper than other illicit drugs (Moore and Pacula 2020). An additional caveat is that we study a supply reduction that comes from drug interdiction activities. Supply reductions resulting from local retail market crackdowns or incarcerating dealers may have different effects.

Reflecting on his experience chairing a National Research Council report on drug policy data and evidence (Manski, Pepper and Petrie 2001), Charles Manski (2003, pp. 543-4) wrote:

I question why the nation has been willing to invest public funds to improve what we know about drug prevention and treatment, but not to learn about drug law enforcement. I regret that... the nation is in no better position to evaluate the effectiveness of enforcement now than it was 20 years ago... I worry that the necessary investments still not having been made, the nation will continue to be engaged 20 years from now in uninformed debate about the effectiveness of its drug control policy.

The large reduction in heroin supply in Australia and the data available for this paper enable us to generate new insights into how opioid users respond to a supply shock, and more general 
insights into the relationships between drugs, health and crime. Hopefully, such findings can aid in developing policies that mitigate the terrible effects of the current opioid crisis, as well as dealing with future drug epidemics. 


\section{References}

Adda, J., McConnell, B. and Rasul, I.: 2014, Crime and the depenalization of cannabis possession: Evidence from a policing experiment, Journal of Political Economy 122(5), 1130-1202.

Ahmad, F. B., Rossen, L. M. and Sutton, P.: 2020, Provisional drug overdose death counts, National Center for Health Statistics .

Alpert, A., Powell, D. and Pacula, R. L.: 2018, Supply-side drug policy in the presence of substitutes: Evidence from the introduction of abuse-deterrent opioids, American Economic Journal: Economic Policy 10(4), 1-35.

Arkes, J., Pacula, R. L., Paddock, S. M., Caulkins, J. P. and Reuter, P.: 2008, Why the DEA Stride data are still useful for understanding drug markets. National Bureau of Economic Research Working Paper No. w14224.

Australian Bureau of Statistics: 2002, Drug-induced deaths-a guide to ABS causes of death data, Canberra: Australian Bureau of Statistics .

Bargagli, A. M., Hickman, M., Davoli, M., Perucci, C. A., Schifano, P., Buster, M., Brugal, T. and Vicente, J.: 2006, Drug-related mortality and its impact on adult mortality in eight European countries, The European Journal of Public Health 16(2), 198-202.

Becker, G. S. and Murphy, K. M.: 1988, A theory of rational addiction, Journal of Political Economy 96(4), 675-700.

Becker, G. S. and Murphy, K. M.: 2013, Have we lost the War on Drugs?, Wall Street Journal . URL: https://www.wsj.com/articles/SB10001424127887324374004578217682305605070

Becker, G. S., Murphy, K. M. and Grossman, M.: 2006, The market for illegal goods: The case of drugs, Journal of Political Economy 114(1), 38-60.

Bell, J. R., Butler, B., Lawrance, A., Batey, R. and Salmelainen, P.: 2009, Comparing overdose mortality associated with methadone and buprenorphine treatment, Drug and Alcohol Dependence 104(1-2), 73-77.

Bipartisan Policy Center: 2020, Tracking FY2019 federal funding to combat the Opioid Crisis. https://bipartisanpolicy.org/wp-content/uploads/2020/09/BPC-Opioids-Report_RV6-1.pdf.

Bondurant, S. R., Lindo, J. M. and Swensen, I. D.: 2018, Substance abuse treatment centers and local crime, Journal of Urban Economics 104, 124-133.

Borusyak, K. and Jaravel, X.: 2017, Revisiting event study designs, Available at SSRN 2826228 .

Burns, L., Randall, D., Hall, W. D., Law, M., Butler, T., Bell, J. and Degenhardt, L.: 2009, Opioid agonist pharmacotherapy in New South Wales from 1985 to 2006: Patient characteristics and patterns and predictors of treatment retention, Addiction 104(8), 1363-1372.

Castillo, J. C., Mejía, D. and Restrepo, P.: 2020, Scarcity without Leviathan: The violent effects of cocaine supply shortages in the Mexican drug war, Review of Economics and Statistics 102(2), 269-286.

Caulkins, J. P., Godkin, C., Gilmour, S. and Dietze, P.: 2006, Heroin and methamphetamine seizures in Victoria, Australia: Purity changes associated with the heroin "drought". Carnegie Mellon University Heinz School Working Paper 2006-8.

Caulkins, J. P. and Reuter, P.: 2010, How drug enforcement affects drug prices, Crime and Justice 39(1), 213-271.

Cawley, J. and Ruhm, C. J.: 2011, The economics of risky health behaviors, Handbook of Health Economics, Vol. 2, Elsevier, pp. 95-199.

Corman, H. and Mocan, H. N.: 2000, A time-series analysis of crime, deterrence, and drug abuse in New York City, American Economic Review 90(3), 584-604. 
Cunningham, S. and Finlay, K.: 2013, Parental substance use and foster care: Evidence from two methamphetamine supply shocks, Economic Inquiry 51(1), 764-782.

Cunningham, S. and Finlay, K.: 2016, Identifying demand responses to illegal drug supply interdictions, Health Economics 25(10), 1268-1290.

Dasgupta, N., Beletsky, L. and Ciccarone, D.: 2018, Opioid crisis: No easy fix to its social and economic determinants, American Journal of Public Health 108(2), 182-186.

Dave, D.: 2006, The effects of cocaine and heroin price on drug-related emergency department visits, Journal of Health Economics 25(2), 311-333.

Dave, D.: 2008, Illicit drug use among arrestees, prices and policy, Journal of Urban Economics 63(2), 694-714.

Dave, D., Deza, M. and Horn, B.: 2021, Prescription drug monitoring programs, opioid abuse, and crime, Southern Economic Journal 87(3), 808-848.

Day, C., Degenhardt, L. and Hall, W.: 2006, Documenting the heroin shortage in New South Wales, Drug and Alcohol Review 25(4), 297-305.

Day, C., Topp, L., Rouen, D., Darke, S., Hall, W. and Dolan, K.: 2003, Decreased heroin availability in Sydney in early 2001, Addiction 98(1), 93-95.

Degenhardt, L., Bucello, C., Mathers, B., Briegleb, C., Ali, H., Hickman, M. and McLaren, J.: 2011, Mortality among regular or dependent users of heroin and other opioids: A systematic review and meta-analysis of cohort studies, Addiction 106(1), 32-51.

Degenhardt, L., Day, C., Dietze, P., Pointer, S., Conroy, E., Collins, L. and Hall, W.: 2005, Effects of a sustained heroin shortage in three Australian States, Addiction 100(7), 908-920.

Degenhardt, L., Day, C. and Hall, W.: 2004, The causes, course, and consequences of the heroin shortage in Australia. National Drug Law Enforcement Research Fund Monograph Series No. 3.

Degenhardt, L., Reuter, P., Collins, L. and Hall, W.: 2005, Evaluating explanations of the Australian 'heroin shortage', Addiction 100(4), 459-469.

Dell, M.: 2015, Trafficking networks and the Mexican drug war, American Economic Review 105(6), 1738-79.

d'Este, R.: 2021, Breaking the crystal methamphetamine economy: Illegal drugs, supply-side interventions and crime responses, Economica 88(349), 208-233.

Dobkin, C. and Nicosia, N.: 2009, The War on Drugs: Methamphetamine, public health, and crime, American Economic Review 99(1), 324-49.

Dobkin, C., Nicosia, N. and Weinberg, M.: 2014, Are supply-side drug control efforts effective? Evaluating OTC regulations targeting methamphetamine precursors, Journal of Public Economics 120, 48-61.

Dobkin, C. and Puller, S. L.: 2007, The effects of government transfers on monthly cycles in drug abuse, hospitalization and mortality, Journal of Public Economics 91(11-12), 2137-2157.

Donnelly, N., Weatherburn, D. and Chilvers, M.: 2004, The impact of the Australian heroin shortage on robbery in NSW. NSW Bureau of Crime Statistics and Research: Crime and Justice Statistics Bureau Brief, March 2004.

Draca, M., Koutmeridis, T. and Machin, S.: 2019, The changing returns to crime: Do criminals respond to prices?, Review of Economic Studies 86(3), 1228-1257.

EMCDDA: 2019, European drug report 2019: Trends and developments, Luxembourg: Publications Office of the European Union.

Evans, W. N., Garthwaite, C. and Moore, T. J.: 2016, The white/black educational gap, stalled progress, and the long-term consequences of the emergence of crack cocaine markets, Review of Economics and Statistics 98(5), 832-847.

Evans, W. N., Lieber, E. M. and Power, P.: 2019, How the reformulation of OxyContin ignited the heroin epidemic, Review of Economics and Statistics 101(1), 1-15.

Evans, W. N. and Moore, T. J.: 2011, The short-term mortality consequences of income receipt, Journal of Public Economics 95(11-12), 1410-1424. 
Gallet, C. A.: 2014, Can price get the monkey off our back? A meta-analysis of illicit drug demand, Health Economics 23(1), 55-68.

Giulietti, C. and McConnell, B.: 2021, Kicking you when you're already down: The multipronged impact of austerity on crime, arXiv preprint arXiv:2012.08133.

Grogger, J. and Willis, M.: 2000, The emergence of crack cocaine and the rise in urban crime rates, Review of Economics and Statistics 82(4), 519-529.

Grossman, M.: 2005, Individual behaviors and substance use: The role of price, Advances in Health Economics and Health Services Research 16, 15-39.

Hall, W., Ross, J., Lynskey, M., Law, M. and Degenhardt, L.: 2000, How many dependent opioid users are there in Australia? National Drug and Alcohol Research Centre (NDARC) Monograph 44.

Hawley, M.: 2002, Heroin shortage: The cause, Platypus Magazine 76, 43-48.

Honoré, B. E. and Lleras-Muney, A.: 2006, Bounds in competing risks models and the war on cancer, Econometrica 74(6), 1675-1698.

Johnston, D. W., Shields, M. A. and Suziedelyte, A.: 2018, Victimisation, well-being and compensation: Using panel data to estimate the costs of violent crime, Economic Journal 128(611), 1545-1569.

Kuziemko, I. and Levitt, S. D.: 2004, An empirical analysis of imprisoning drug offenders, Journal of Public Economics 88(9-10), 2043-2066.

Lancaster, K., Hughes, C. E., Spicer, B., Matthew-Simmons, F. and Dillon, P.: 2011, Illicit drugs and the media: Models of media effects for use in drug policy research, Drug and Alcohol Review 30(4), 397-402.

Levitt, S. D. and Venkatesh, S. A.: 2000, An economic analysis of a drug-selling gang's finances, Quarterly Journal of Economics 115(3), 755-789.

MacCoun, R., Kilmer, B. and Reuter, P.: 2003, Research on drugs-crime linkages: The next generation, National Institute of Justice Special Report July, 65-95.

Maher, L. and Dixon, D.: 2001, The cost of crackdowns: Policing Cabramatta's heroin market, Current Issues in Criminal Justice 13(1), 5-22.

Manski, C. F., Pepper, J. V. and Petrie, C. V.: 2001, Informing America's policy on illegal drugs: What we don't know keeps hurting us, National Academies Press.

Mayhew, P.: 2003, Counting the costs of crime in Australia: Techinical report. AIC Technical and Background Paper Series No. 4.

Moore, T. J.: 2006, Australian illicit drug market data: Sources and issues, Australian Economic Review 39(4), 442-452.

Moore, T. J.: 2008, The size and mix of government spending on illicit drug policy in Australia, Drug and Alcohol Review 27(4), 404-413.

Moore, T. J. and Pacula, R. L.: 2020, The causes and consequences of illicit drug epidemics, in D. Marcotte and K. Zimmermann (eds), Handbook of Labor, Human Resources and Population Economics, Springer Nature, Cham Switzerland. forthcoming.

National Centre in HIV Epidemiology and Clinical Research: 2007, Sydney Medically Supervised Injecting Centre Evaluation Report No. 4: Evaluation of service operation and overdose-related events, University of New South Wales, Sydney, NSW.

National Survey of Substance Abuse Treatment Services: 2020, Data on Substance Abuse Treatment Facilities: 2019, Substance Abuse and Mental Health Services Administration.

Pieper, R.: 2006, Trends in law enforcement and border operations in the Asia-Pacific, Development Bulletin 69, 18-21.

Pollack, H. A. and Reuter, P.: 2014, Does tougher enforcement make drugs more expensive?, Addiction 109(12), 1959-1966.

Quilter, J. and McNamara, L.: 2017, 'Zero tolerance' drug driving laws in Australia: A gap between rationale and form?, International Journal for Crime, Justice and Social Democracy 6(3).

Raphael, S. and Stoll, M. A.: 2013, Why are so many Americans in prison?, Russell Sage Foundation. 
Reuter, P.: 2009, Main report: Assessing changes in global drug problems, 1998-2007, in P. Reuter and F. Trautmann (eds), A report on global illicit drugs markets 1998-200\%, European Commission.

Reuter, P.: 2010, Understanding the demand for illegal drugs., National Academies Press.

Reuter, P.: 2017, Creating a drug law enforcement research agenda, International Journal of Drug Policy 41, 160-161.

Shearer, J., Johnston, J., Fry, C. L., Kaye, S., Dillon, P., Dietze, P. and Collins, L.: 2008, An Australian profile on cocaine supply, The Howard Journal of Criminal Justice 47(1), 67-80.

Smart, R., Kase, C. A., Taylor, E. A., Lumsden, S., Smith, S. R. and Stein, B. D.: 2020, Strengths and weaknesses of existing data sources to support research to address the opioid crisis, Preventive Medicine Reports 17, 101015.

Smith, R. G., Jorna, P., Sweeney, J., Fuller, G. et al.: 2014, Counting the costs of crime in Australia: A 2011 estimate. AIC Research and Public Policy series No. 129.

Smithson, M., McFadden, M., Mwesigye, S.-E. and Casey, T.: 2004, The impact of illicit drug supply reduction on health and social outcomes: The heroin shortage in the Australian Capital Territory, Addiction 99(3), 340-348.

Snowball, L., Moffatt, S., Weatherburn, D. and Burgess, M.: 2008, Did the heroin shortage increase amphetamine use? A time series analysis., Crime and Justice Bulletin (114), 1-8.

State of NSW: 2009, Drug Court of NSW 2008 in review, NSW Attorney General's Department. URL: https://www.drugcourt.nsw.gov.au/drug-court/publications/annual-reviews.html

Swensen, I. D.: 2015, Substance-abuse treatment and mortality, Journal of Public Economics 122, 13-30.

Topp, L., Kaye, S., Bruno, R. B., Longo, M., Williams, P., O’Reilly, B., Fry, C. L., Rose, G. and Darke, S.: 2002, Australian drug trends 2001: Findings of the Illicit Drug Reporting System (IDRS), University of New South Wales.

U.S. Sentencing Commission: 2020, Overview of Federal Criminal Cases, Fiscal Year 2019. https: //www.ussc.gov/research/data-reports/overview-federal-criminal-cases-fiscal-year-2019.

Viscusi, W. K.: 2018, Pricing lives: International guideposts for safety, Economic Record 94, 1-10.

Weatherburn, D., Jones, C., Freeman, K. and Makkai, T.: 2003, Supply control and harm reduction: Lessons from the Australian heroin 'drought', Addiction 98(1), 83-91.

Werb, D., Rowell, G., Guyatt, G., Kerr, T., Montaner, J. and Wood, E.: 2011, Effect of drug law enforcement on drug market violence: A systematic review, International Journal of Drug Policy 22(2), 87-94.

Winstock, A. R., Lea, T. and Sheridan, J.: 2010, Problems experienced by community pharmacists delivering opioid substitution treatment in New South Wales and Victoria, Australia, Addiction 105(2), 335-342. 


\section{$7 \quad$ Figures and Tables}

Figure 1: Opioids in New South Wales

(a) Opioid deaths and the price of heroin in New South Wales

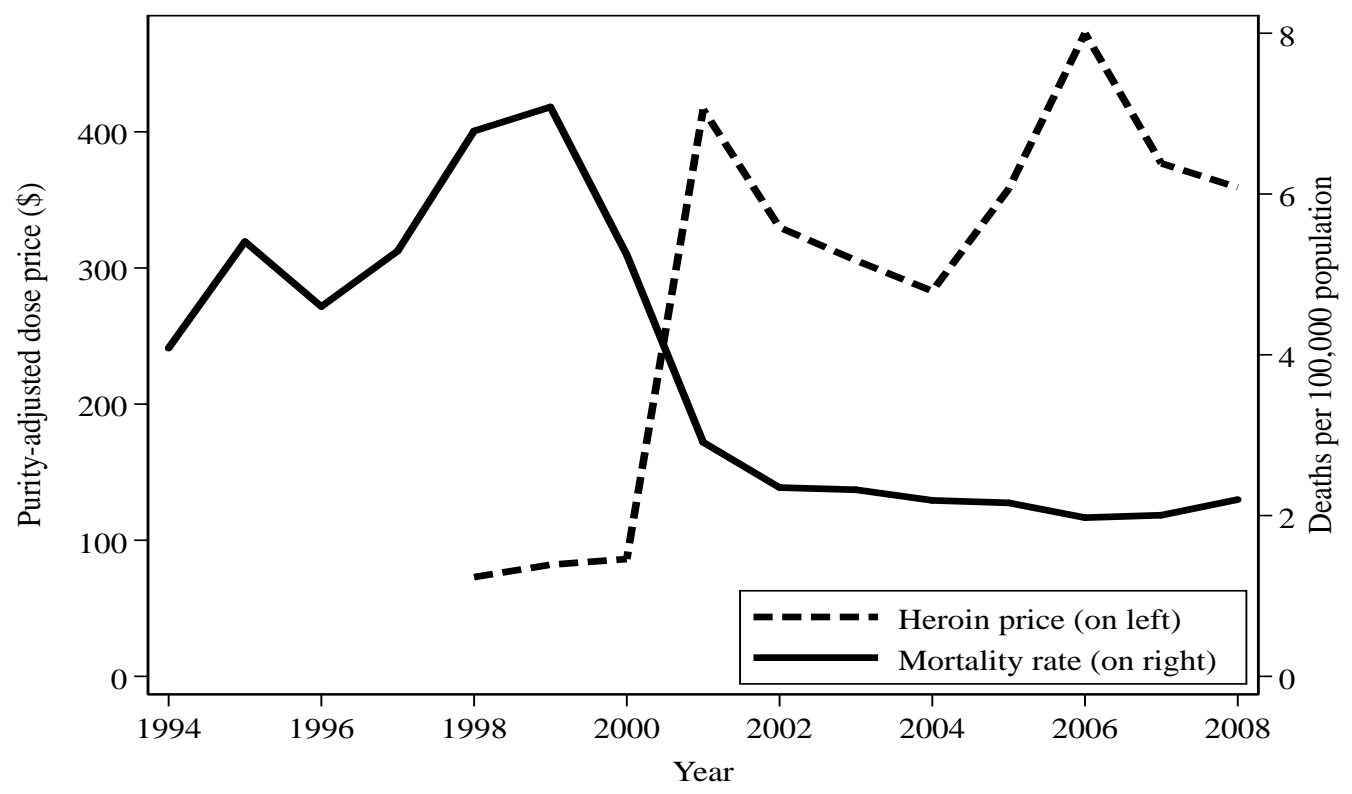

(b) Opioid deaths in New South Wales and the United States, 14 years apart

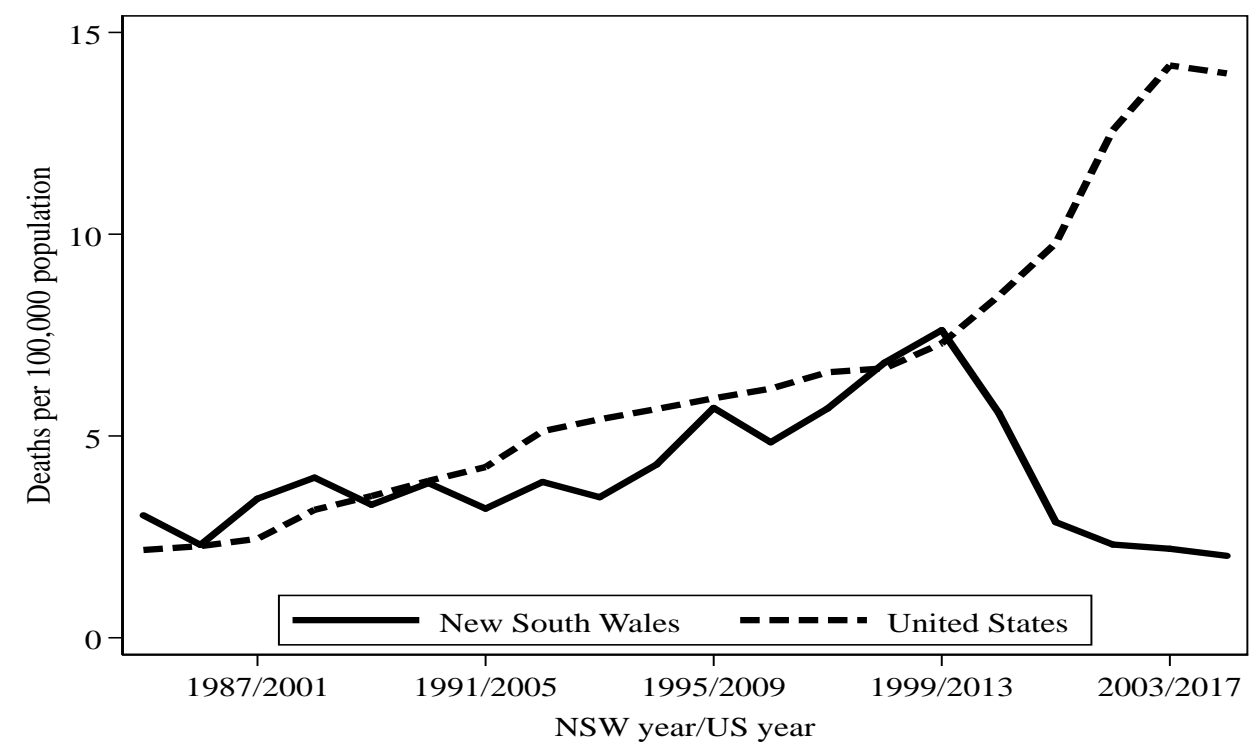

Notes: The NSW opioid-related mortality rate uses data from the Australian Institute for Health and Welfare. Pure heroin prices come from reported prices paid divided by average heroin purity; these data are from the Illicit Drug Reporting System and Victoria Police Forensic Science Centre. US mortality rates data are calculated using the Centers for Disease Control and Prevention's WONDER database. See footnotes 1, 2 and 8 for details. 
Figure 2: Opioid-specific outcomes

\section{RAW DATA:}

(a) Opioid-related mortality

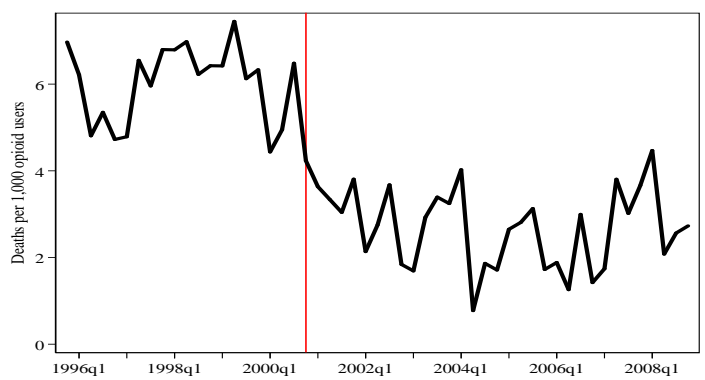

(c) Opioid use/possession offense rates

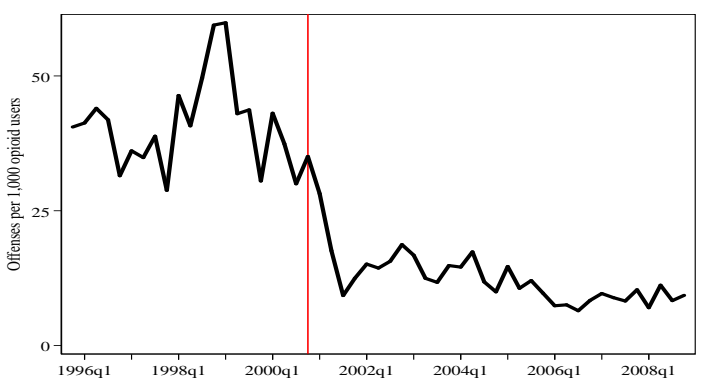

(e) Opioid use/poss. off. (w/o crackdown)

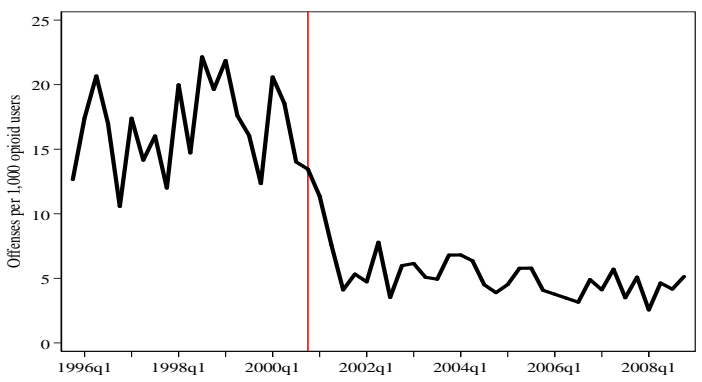

(g) Opioid supply/distribution offense rates

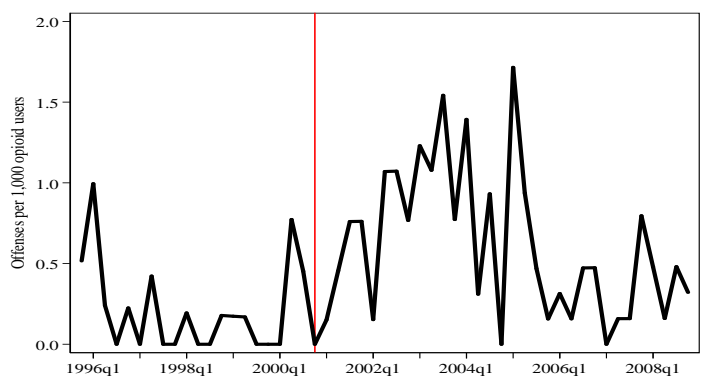

EVENT STUDY ESTIMATES:

(b) Opioid-related mortality

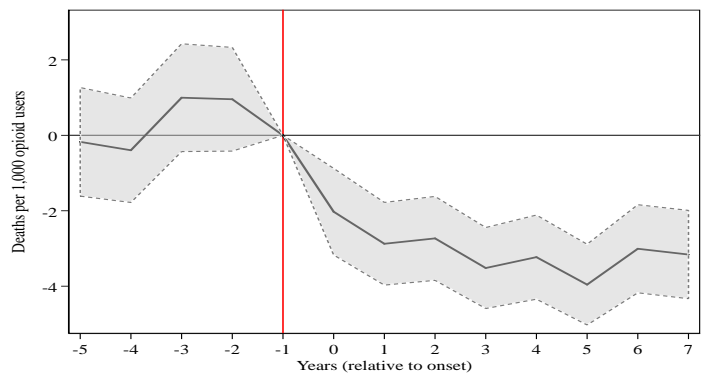

(d) Opioid use/possession offense rates

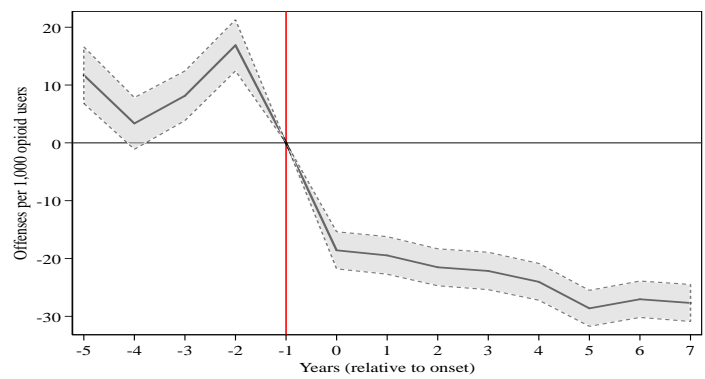

(f) Opioid use/poss. off. (w/o crackdown areas)

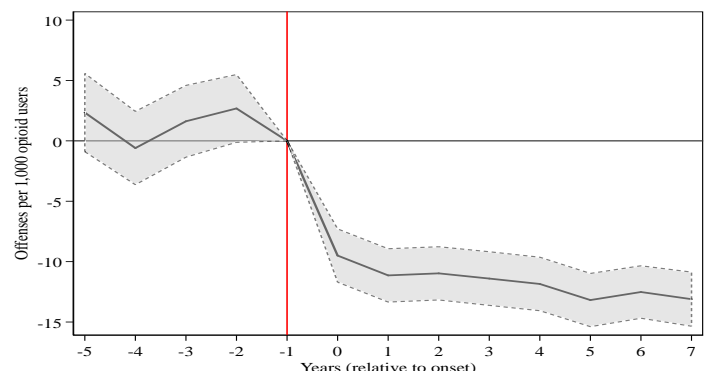

(h) Opioid supply/distribution offense rates

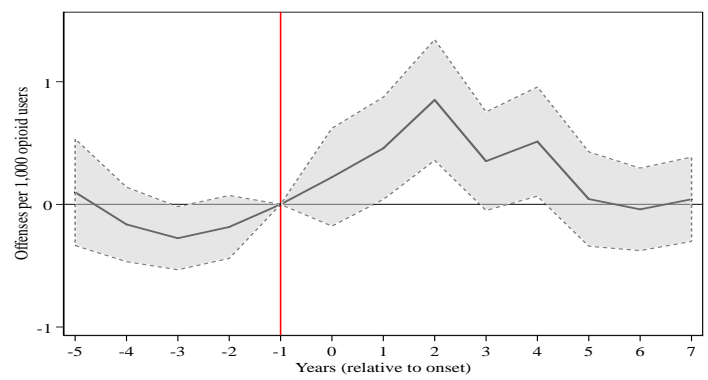

Notes: The left column shows unadjusted quarterly rates for our sample of opioid users. A vertical red line marks the onset of the heroin supply reduction in 2000-Q4. The right column shows the estimated coefficients and $95 \%$ confidence intervals for the event-year indicator variables from Eq (1) in Section 3. The reference period is the 12 months before the onset of the heroin reduction in 2000 Q4, which is identified with a vertical red line. The mortality outcome in panel (b) is estimated without individual fixed effects and extra demographic controls. Rates in all panels are scaled to represent annual outcomes per 1,000 individuals. Panels (e) and (f) exclude offenses processed in courts close to the two major heroin street markets in Sydney, which were subject to police crackdowns in 1998 and 1999 (near Cabramatta: Fairfield and Liverpool; near Central Sydney/Kings Cross: Sydney Downing Centre, Central and Redfern). 
Figure 3: Event study estimates for non-opioid drug and alcohol outcomes

(a) Mortality related to non-opioid drugs \& alcohol

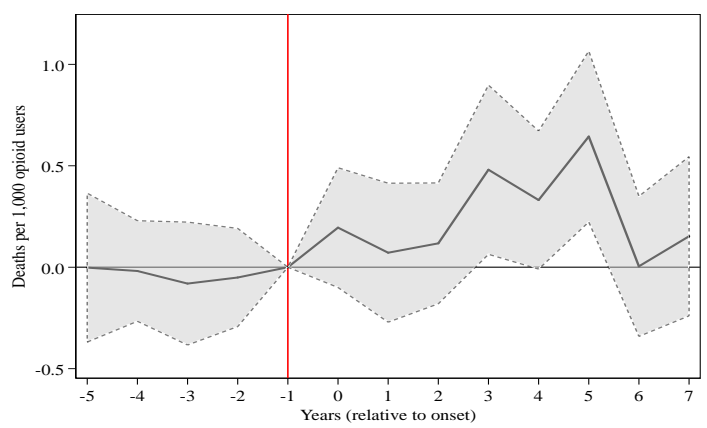

(c) Methamphetamine use/possession

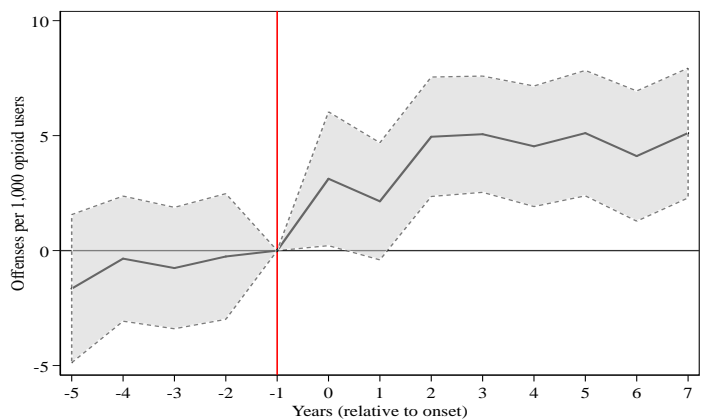

(e) Non-opioid illicit drug supply/distribution

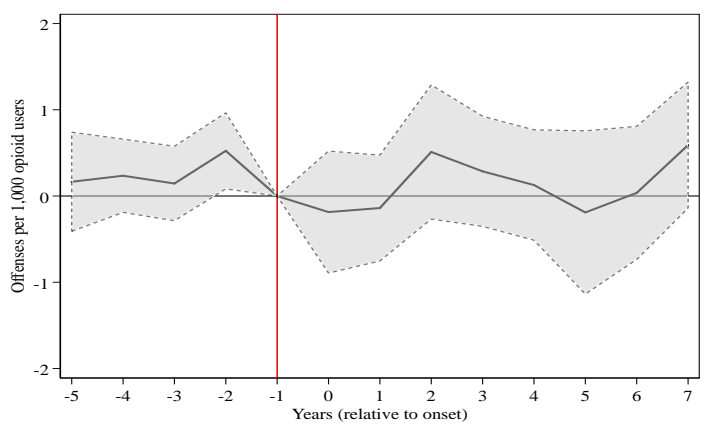

(g) Driving causing death

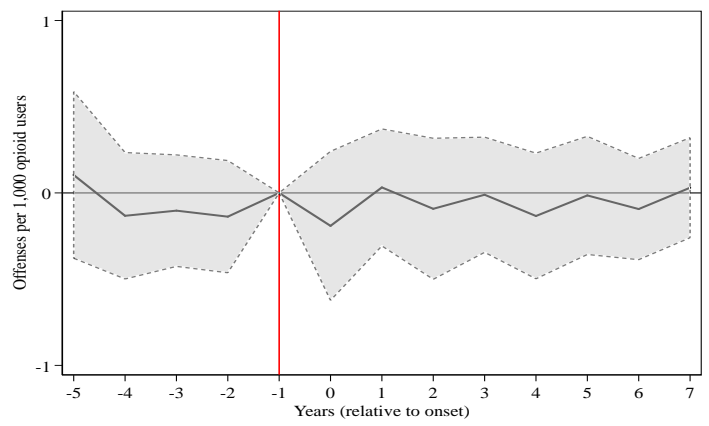

(b) Non-opioid illicit drug use/possession

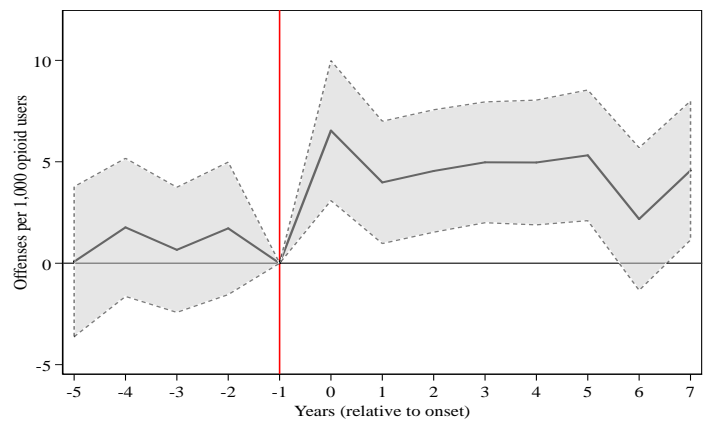

(d) Cocaine use/possession

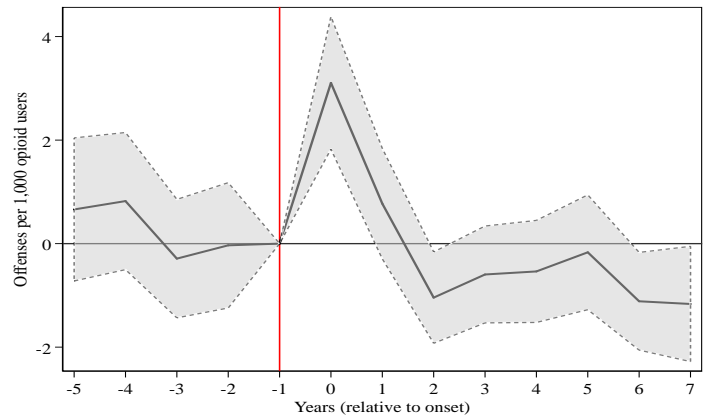

(f) Driving under the influence of alcohol

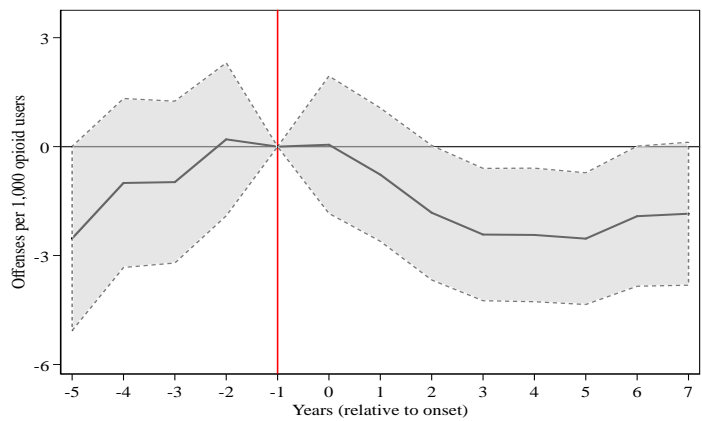

Notes: This figure shows the estimated coefficients and $95 \%$ confidence intervals for the treatment-group year indicator variables in the event study specification described by Eq (1) in Section 3. The specifications use data from our treatment group of opioid users along with data from the comparison group of non-opioid drug offenders. The reference period is the 12 months before the onset of the heroin reduction in $2000 \mathrm{Q} 4$, which is identified with a vertical red line. All estimates are scaled to represent annual outcomes per 1,000 individuals. The mortality outcome in panel (a) is estimated without individual fixed effects and extra demographic controls. Panel (b) uses a broad measure of non-opioid illicit drugs that includes the methamphetamine and cocaine outcomes used in panels (c) and (d), respectively. 
Figure 4: Event study estimates for mortality and all violent and property criminal offenses

(a) Overall mortality

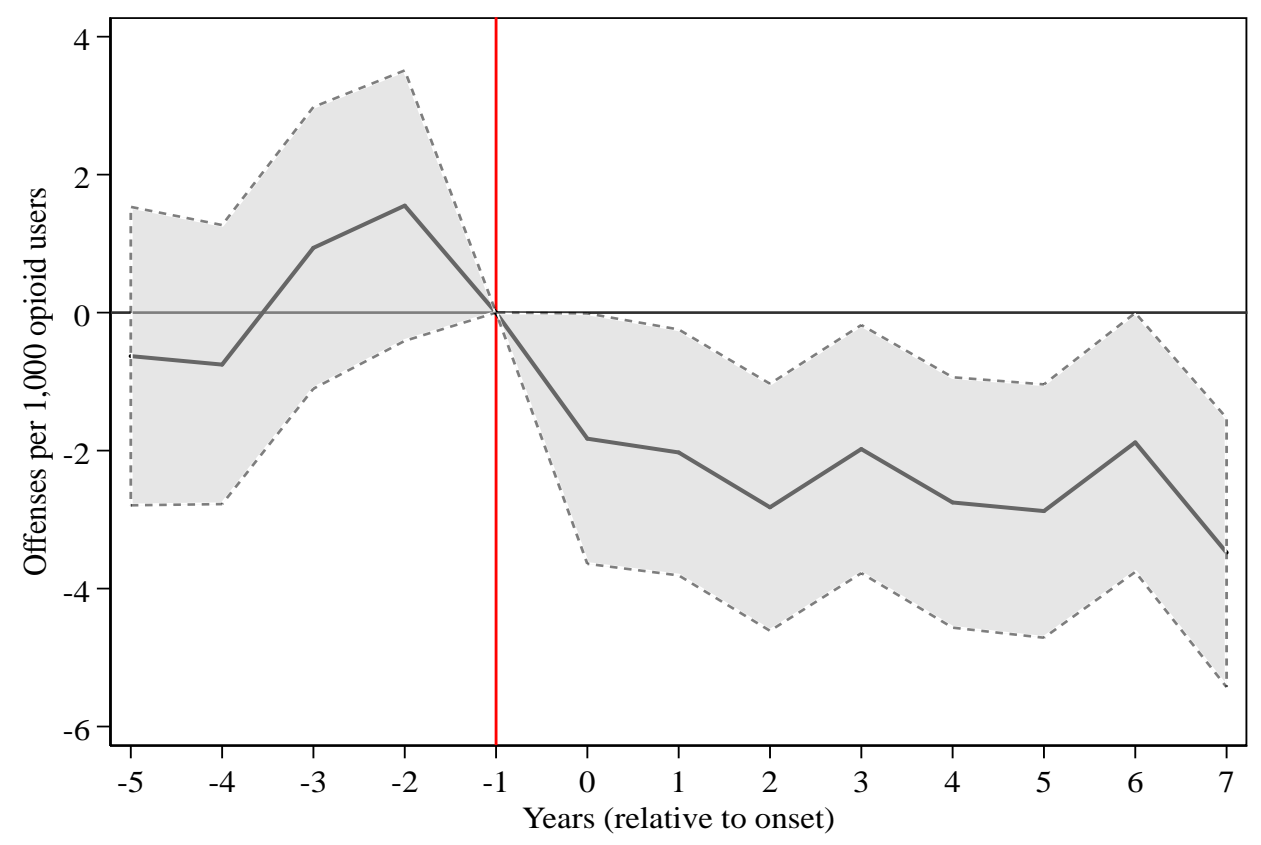

(b) Total violent and property offenses

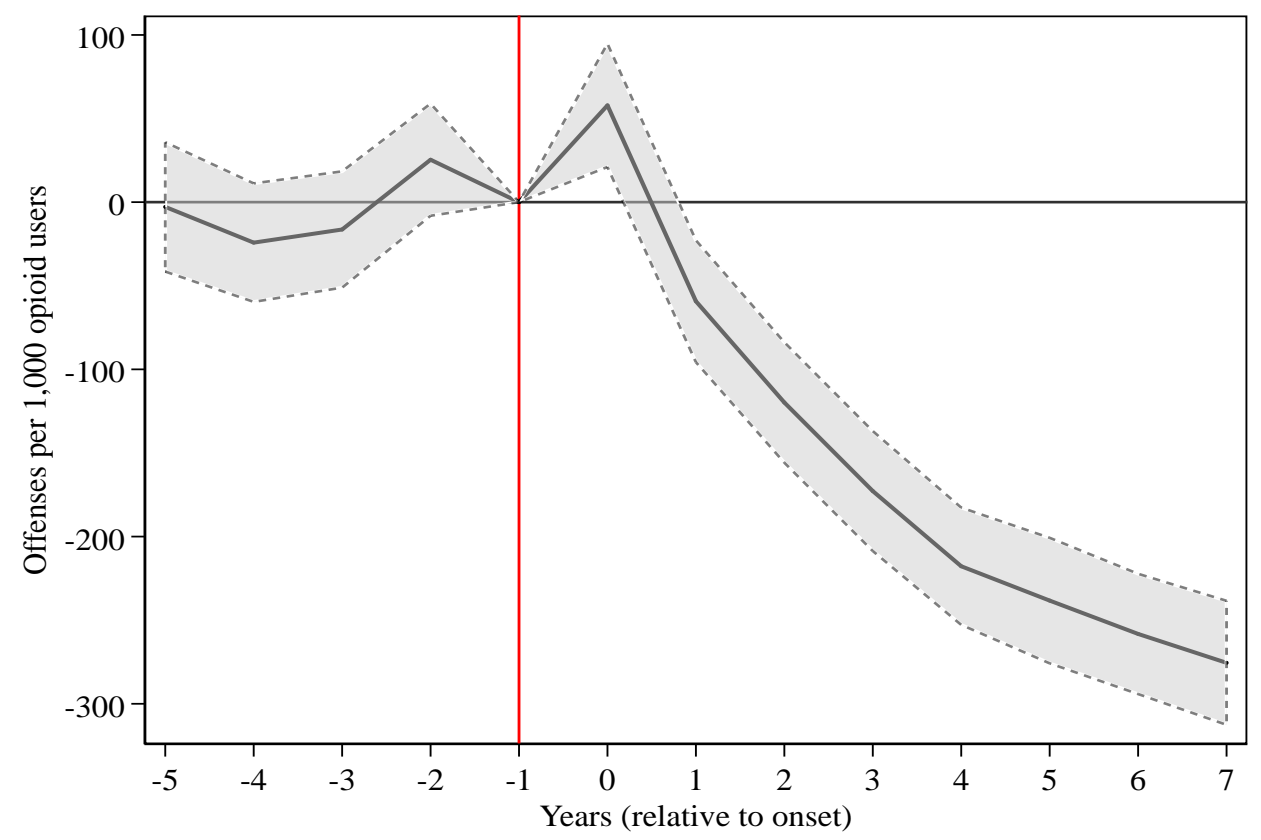

Notes: This figure shows the estimated coefficients and $95 \%$ confidence intervals for the treatment-group year indicator variables in the event study specification described by Eq (1) in Section 3. The specification uses data from our treatment group of opioid users along with data from the comparison group of non-opioid drug offenders. The reference period is the 12 months before the onset of the heroin reduction in 2000 Q4, which is identified with a vertical red line. All estimates are scaled to represent annual outcomes per 1,000 individuals. For panel (a), the specification does not include individual fixed effects. 
Figure 5: Event study estimates for specific violent and property offenses

(a) : Violent - Murder

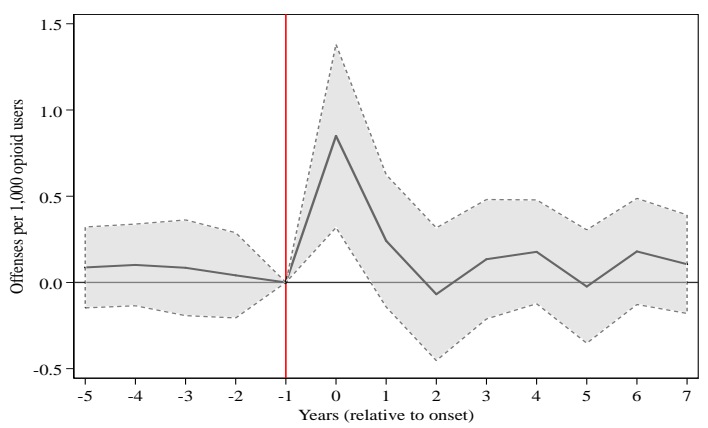

(c) Violent - Sexual Assault

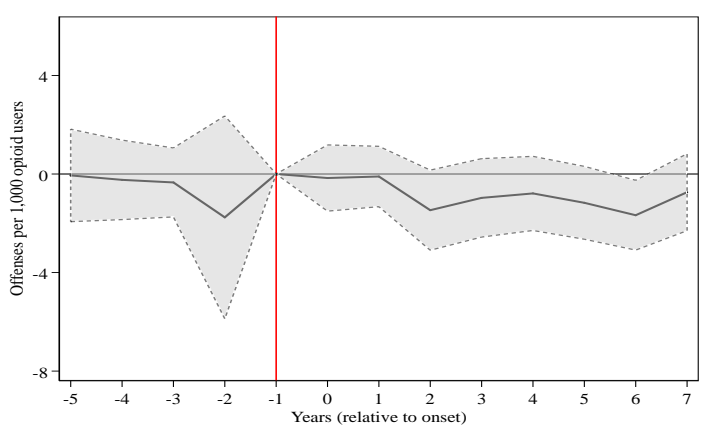

(e) Property - Robbery

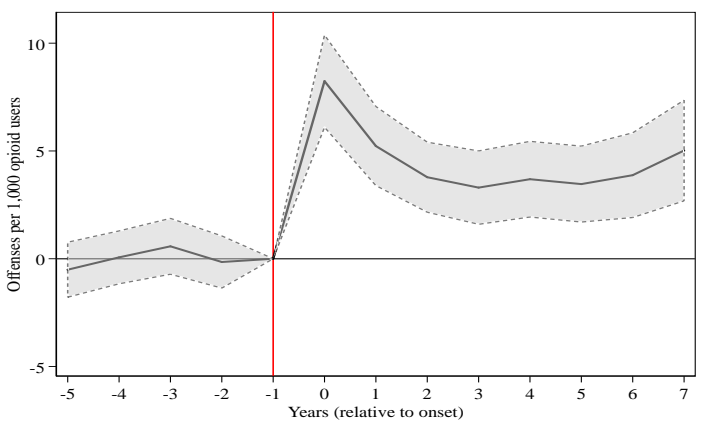

(g) Property - Motor vehicle theft

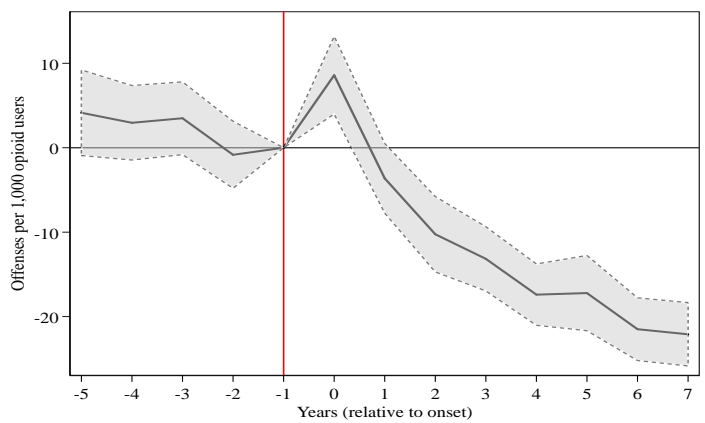

(b) Violent - Assault

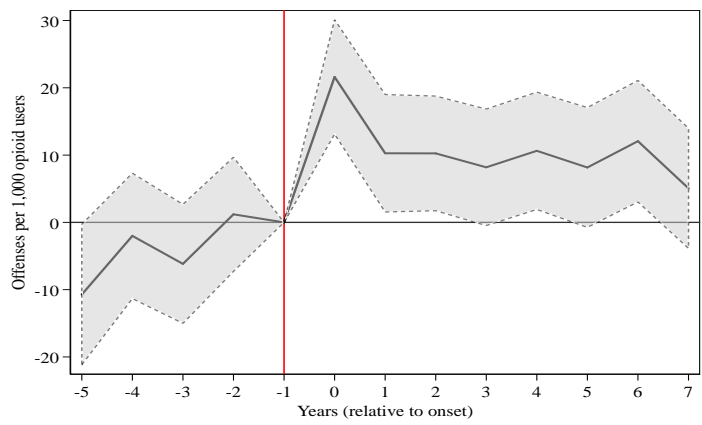

(d) Violent - Harassment

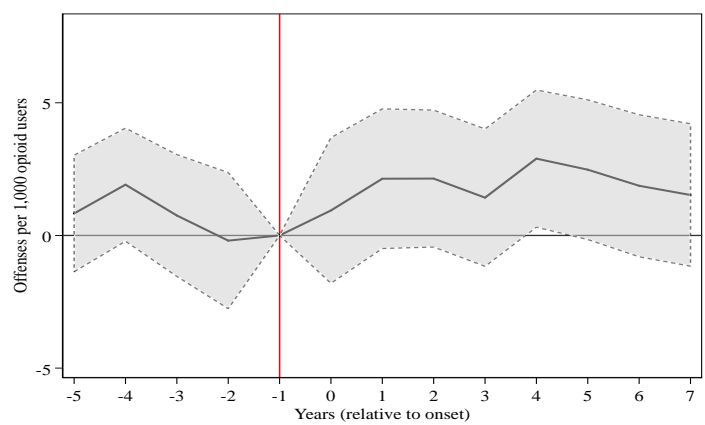

(f) Property - Burglary/break \& enter

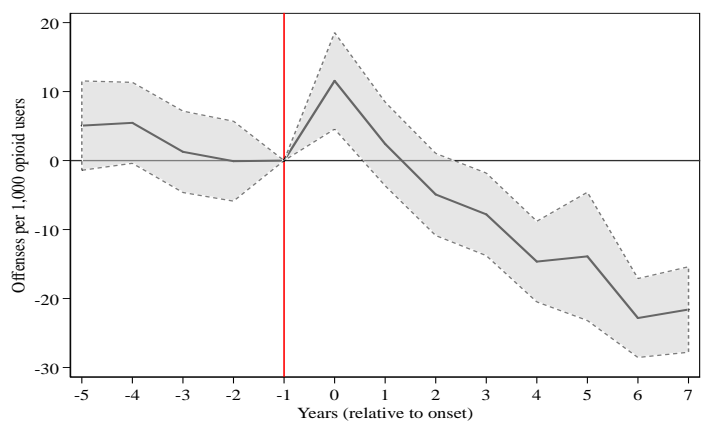

(h) Property - Other theft

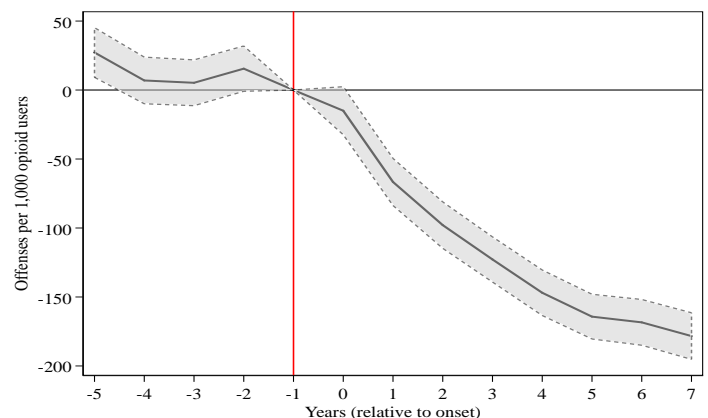

Notes: This figure shows the estimated coefficients and $95 \%$ confidence intervals for the treatment-group year indicator variables in the event study specification described by Eq (1) in Section 3. The specification uses data from our treatment group of opioid users along with data from the comparison group of non-opioid drug offenders. The reference period is the 12 months before the onset of the heroin reduction in 2000 Q4, which is identified with a vertical red line. All estimates are scaled to represent annual outcomes per 1,000 individuals. Panels (a)-(d) are specific violent offenses and panels (e)-(h) are specific property offenses. 
Figure 6: Comparison of event study estimates with and without a comparison group

(a) Opioid-related mortality

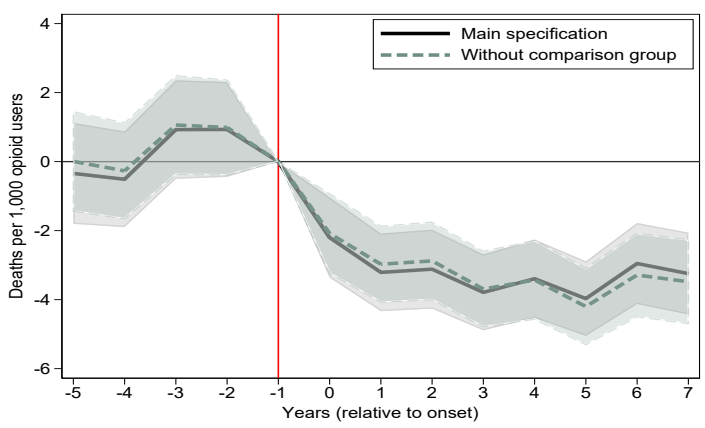

(c) Non-opioid illicit drug use/possession

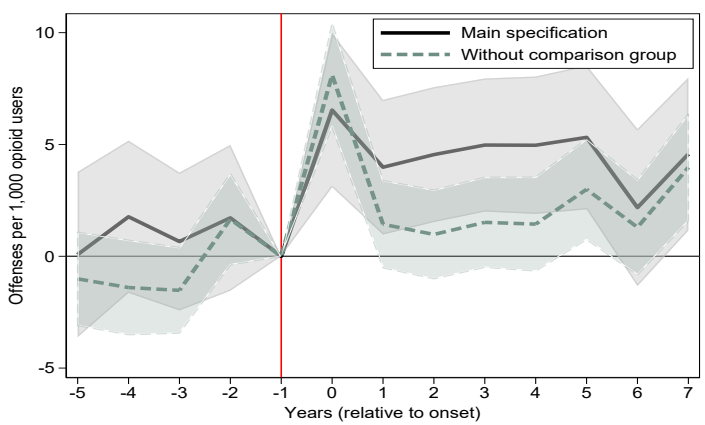

(e) Cocaine use/possession

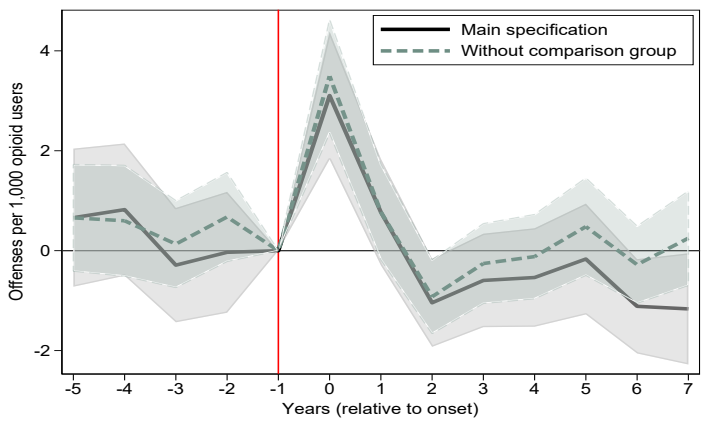

(g) Violent offenses

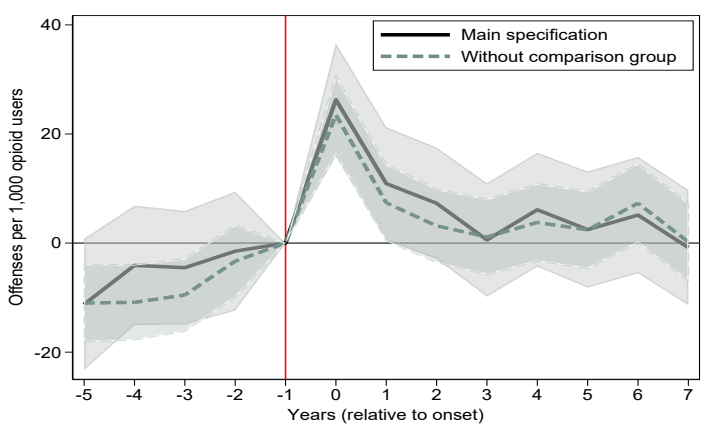

(b) Opioid use/poss. off. (w/o crackdown areas)

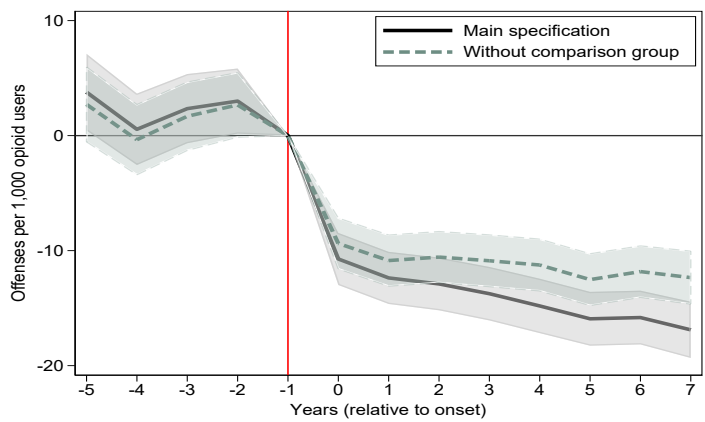

(d) Methamphetamine use/possession

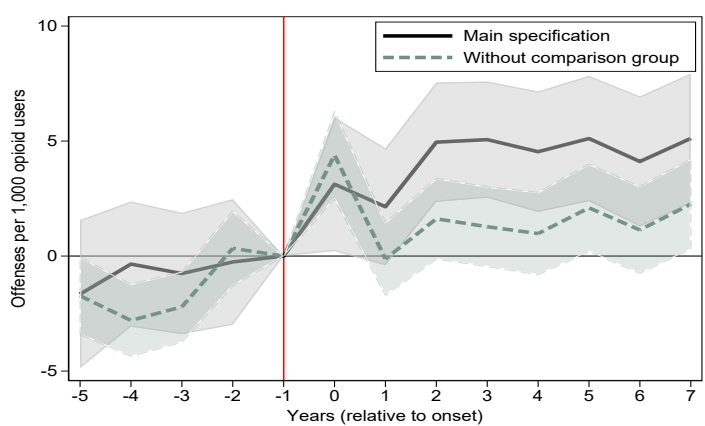

(f) Overall mortality

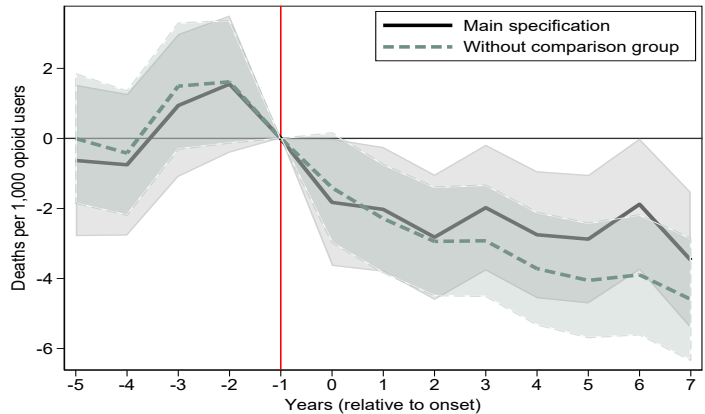

(h) Property offenses

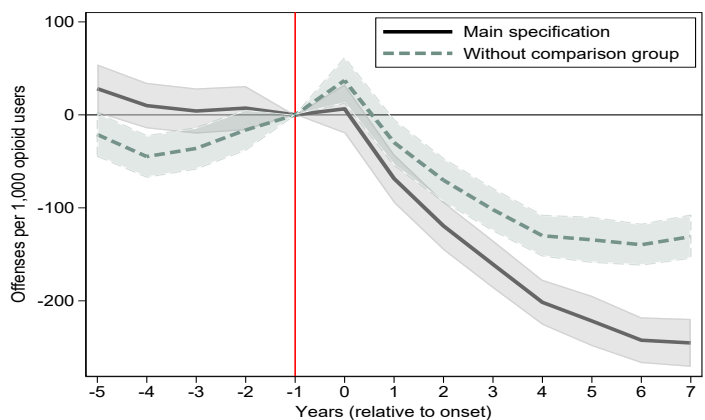

Notes: This figure shows the estimated coefficients and $95 \%$ confidence intervals for the treatment-group year indicator variables in the event study specifications with a comparison group of non-opioid drug offenders (main specification given by Eq (1)) as well as the specification without a comparison group (given by Eq (2)). The reference period is the 12 months before the onset of the heroin reduction in 2000 Q4, which is identified with a vertical red line. All estimates are scaled to represent annual outcomes per 1,000 individuals. See text for more details. 
Table 1: Mean sample characteristics prior to heroin supply reduction

$\begin{array}{cc}\text { Opioid } & \text { Non-opioid } \\ \text { user } & \text { drug offender } \\ \text { sample } & \text { sample }\end{array}$

Demographic characteristics

Age

$\begin{array}{ll}33.8 & 30.2 \\ 0.30 & 0.13\end{array}$

Female

0.30

0.13

Annualized incidence rates per 1000 individuals

\begin{tabular}{lcc}
\hline Mortality & 9.49 & 2.28 \\
Opioid-related mortality & 5.82 & 0 \\
Non-opoid drug or alchol related mortality & 0.15 & 0.077 \\
Mortality not related to drugs or alcohol & 3.52 & 2.21 \\
Illicit drug offending: & & \\
Opioid use/possession & 40.8 & 0 \\
Non-opioid illicit drug use/possession & 8.33 & 9.24 \\
Cocaine use/possession & 2.12 & 0.88 \\
Methamphetamine use/possession & 5.08 & 7.42 \\
Opioid supply/distribution & 0.20 & 0 \\
Non-opioid illicit drug sale/distribution & 0.14 & 0.22 \\
Violent offending & 78.4 & 94.4 \\
Homicide & 0.036 & 0.088 \\
Assault & 56.9 & 74.1 \\
Sex assault & 0.68 & 2.38 \\
Harassment & 1.16 & 2.98 \\
Property offending & 340.5 & 80.1 \\
Robbery & 1.44 & 0.92 \\
Burglary/break \& enter & 38.1 & 12.0 \\
Motor vehicle theft & 25.4 & 7.93 \\
Theft (non motor vehicle) & 233.3 & 45.5 \\
\hline No. of unique individuals & 27,467 & 25,745 \\
\hline
\end{tabular}

Notes: This table presents mean characteristics for the five years prior to the reduction in heroin supply (1995:Q4-2000:Q3) for our sample of opioid users and the comparison group of non-opioid drug offenders. Our sample of opioid users comprise everyone entering the NSW Opioid Treatment Program from 1985 (earliest available data) to the third quarter of 2000. Our comparison sample consists of all individuals with a non-opioid illicit drug charge in the criminal charge database from 1994 (earliest available data) to the third quarter of 2000 who never entered opioid treatment. Key outcome variables are presented in terms of annualized incidence rates per 1,000 individuals. 
Table 3: Heterogeneous effects (per 1,000 individuals)

\begin{tabular}{|c|c|c|c|c|c|c|c|c|}
\hline & \multicolumn{2}{|c|}{ Mortality } & \multicolumn{2}{|c|}{$\begin{array}{c}\text { Non-opioid } \\
\text { drug use/possession }\end{array}$} & \multicolumn{2}{|c|}{ Violent offenses } & \multicolumn{2}{|c|}{ Property offenses } \\
\hline & \multicolumn{2}{|c|}{ (1) } & \multicolumn{2}{|c|}{$(2)$} & \multicolumn{2}{|c|}{ (3) } & \multicolumn{2}{|c|}{ (4) } \\
\hline & $\begin{array}{c}\text { Year } \\
0\end{array}$ & $\begin{array}{l}\text { Years } \\
2 \text { to } 7\end{array}$ & $\begin{array}{c}\text { Year } \\
0\end{array}$ & $\begin{array}{l}\text { Years } \\
2 \text { to } 7\end{array}$ & $\begin{array}{c}\text { Year } \\
0\end{array}$ & $\begin{array}{l}\text { Years } \\
2 \text { to } 7\end{array}$ & $\begin{array}{l}\text { Year } \\
0\end{array}$ & $\begin{array}{l}\text { Years } \\
2 \text { to } 7\end{array}$ \\
\hline \multicolumn{9}{|l|}{ A. Sex: } \\
\hline Male (a) & $\begin{array}{l}-1.36 \\
(1.05)\end{array}$ & $\begin{array}{l}-3.53^{* *} \\
(0.77)\end{array}$ & $\begin{array}{l}7.64^{* *} \\
(1.91)\end{array}$ & $\begin{array}{l}5.07^{* *} \\
(1.38)\end{array}$ & $\begin{array}{l}33.8^{* *} \\
(5.89)\end{array}$ & $\begin{array}{c}5.20 \\
(4.73)\end{array}$ & $\begin{array}{c}18.4 \\
(15.8)\end{array}$ & $\begin{array}{c}-205.5^{* *} \\
(12.8)\end{array}$ \\
\hline Avg. in ref. period & 10.62 & 10.62 & 8.83 & 8.83 & 97.35 & 97.35 & 374.61 & 374.61 \\
\hline Female (b) & $\begin{array}{l}-2.87^{* *} \\
(1.02)\end{array}$ & $\begin{array}{l}-0.48 \\
(0.78)\end{array}$ & $\begin{array}{c}3.90 \\
(2.35)\end{array}$ & $\begin{array}{c}2.51 \\
(1.96)\end{array}$ & $\begin{array}{c}8.62 \\
(5.99)\end{array}$ & $\begin{array}{l}-1.62 \\
(4.94)\end{array}$ & $\begin{array}{l}-19.1 \\
(17.0)\end{array}$ & $\begin{array}{c}-173.9^{* *} \\
(14.2)\end{array}$ \\
\hline Avg. in ref. period & 5.47 & 5.47 & 8.20 & 8.20 & 57.80 & 57.80 & 343.53 & 343.53 \\
\hline P-value: $(a)=(b)$ & 0.14 & 0.00 & 0.10 & 0.20 & 0.00 & 0.17 & 0.05 & 0.04 \\
\hline \multicolumn{9}{|l|}{ B. Age at shortage: } \\
\hline$\leq 32$ years $(\mathrm{c})$ & $\begin{array}{l}-2.00 \\
(1.05)\end{array}$ & $\begin{array}{l}-2.91^{* *} \\
(0.74)\end{array}$ & $\begin{array}{l}8.99^{* *} \\
(2.29)\end{array}$ & $\begin{array}{l}5.75^{* *} \\
(1.53)\end{array}$ & $\begin{array}{l}40.6^{* *} \\
(7.14)\end{array}$ & $\begin{array}{c}5.03 \\
(5.28)\end{array}$ & $\begin{array}{l}22.5 \\
(20.0)\end{array}$ & $\begin{array}{c}-257.5^{* *} \\
(14.7)\end{array}$ \\
\hline Avg. in ref. period & 7.49 & 7.49 & 10.78 & 10.78 & 118.62 & 118.62 & 552.01 & 552.01 \\
\hline$>32$ years $(\mathrm{d})$ & $\begin{array}{l}-1.68 \\
(1.10)\end{array}$ & $\begin{array}{l}-2.39^{* *} \\
(0.82)\end{array}$ & $\begin{array}{c}4.52^{*} \\
(1.89)\end{array}$ & $\begin{array}{c}3.05^{*} \\
(1.47)\end{array}$ & $\begin{array}{l}14.7^{* *} \\
(5.37)\end{array}$ & $\begin{array}{c}2.76 \\
(4.51)\end{array}$ & $\begin{array}{c}-5.85 \\
(14.3)\end{array}$ & $\begin{array}{c}-134.2^{* *} \\
(12.0)\end{array}$ \\
\hline Avg. in ref. period & 10.03 & 10.03 & 6.97 & 6.97 & 59.57 & 59.57 & 219.25 & 219.2 \\
\hline P-value: $(\mathrm{c})=(\mathrm{d})$ & 0.77 & 0.34 & 0.04 & 0.08 & 0.00 & 0.64 & 0.18 & 0.00 \\
\hline
\end{tabular}

C. Max methadone dose:

\begin{tabular}{|c|c|c|c|c|c|c|c|c|}
\hline$\leq 150 \mathrm{mg}(\mathrm{e})$ & $\begin{array}{l}-3.36^{* *} \\
(1.11)\end{array}$ & $\begin{array}{l}-5.58^{* *} \\
(0.78)\end{array}$ & $\begin{array}{c}1.82 \\
(1.97)\end{array}$ & $\begin{array}{c}3.30^{*} \\
(1.43)\end{array}$ & $\begin{array}{l}15.3^{*} \\
(6.32)\end{array}$ & $\begin{array}{c}1.35 \\
(4.79)\end{array}$ & $\begin{array}{c}-6.91 \\
(18.5)\end{array}$ & $\begin{array}{c}-178.2^{* *} \\
(12.7)\end{array}$ \\
\hline Avg. in ref. period & 11.25 & 11.25 & 8.12 & 8.12 & 77.60 & 77.60 & 299.27 & 299.27 \\
\hline$>150 \mathrm{mg}(\mathrm{f})$ & $\begin{array}{l}-0.94 \\
(1.03)\end{array}$ & $\begin{array}{l}-0.95 \\
(0.75)\end{array}$ & $\begin{array}{l}9.29^{* *} \\
(2.02)\end{array}$ & $\begin{array}{l}5.09^{* *} \\
(1.35)\end{array}$ & $\begin{array}{c}32.7^{* *} \\
(5.88)\end{array}$ & $\begin{array}{c}4.72 \\
(4.46)\end{array}$ & $\begin{array}{c}14.0 \\
(15.5)\end{array}$ & $\begin{array}{c}-210.2^{* *} \\
(12.5)\end{array}$ \\
\hline Avg. in ref. period & 7.76 & 7.76 & 8.95 & 8.95 & 90.20 & 90.20 & 404.93 & 404.93 \\
\hline P-value: $(e)=(f)$ & 0.03 & 0.00 & 0.00 & 0.09 & 0.00 & 0.32 & 0.30 & 0.00 \\
\hline
\end{tabular}

$* \mathrm{p}<0.05,{ }^{* *} \mathrm{p}<0.01$.

Notes: This table summarizes the heterogeneous effects of the heroin reduction. We present estimated coefficients for selected treatment group by year indicator variables in the event study specification described by Eq (2) in Section 3, which are further interacted with indicator variables identifying our subgroups of interest (e.g., males and females). The specifications use data from our treatment group of opioid users along with data from the control group of non-opioid drug offenders. The reference period is the 12 months before the onset of the heroin reduction in 2000 Q4, denoted as Year -1. All estimates are scaled to represent annual outcomes per 1,000 individuals. Standard errors are robust to arbitrary correlation within individuals over time, and when coefficients are averaged across multiple years the delta method is used to calculate standard errors. To help understand the relative size of the effects, we show the treatment group mean for each outcome variable in the reference period (Year -1). For each characteristic of interest, we report the p-value on the hypothesis test that the coefficients are equal. Each regression uses 2,439,641 observations. 


\section{Appendix A: Additional Figures and Tables}

Figure A1: Prices of heroin, cocaine and methamphetamine, relative to year 2000

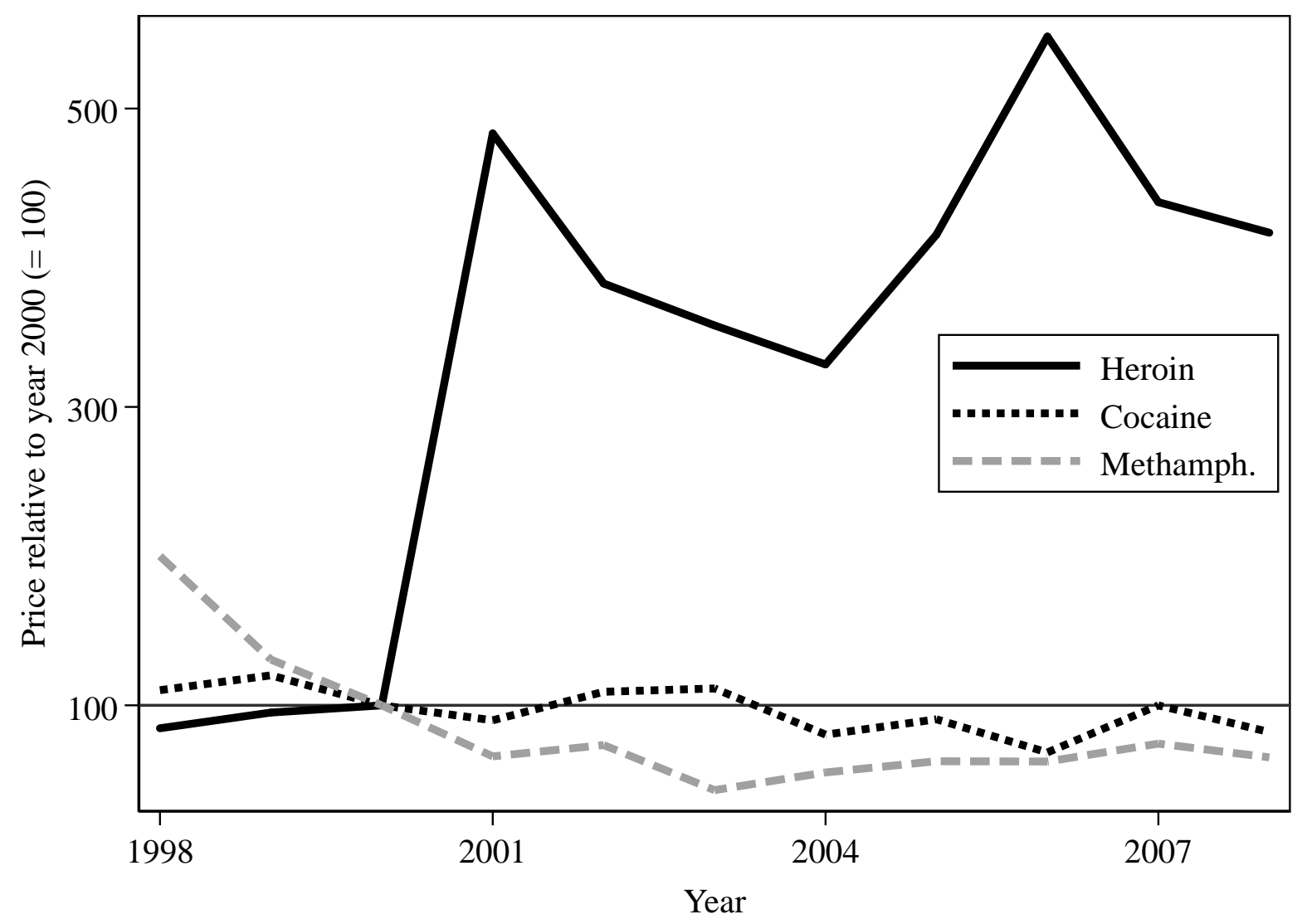

Notes: These are purity-adjusted prices for doses of heroin, cocaine and methamphetamine relative to the year 2000. They are constructed by dividing retail prices (from a survey of regular injecting drug users) by the average purities (from police forensic analyses of retail-level quantities). We use annual survey data on the prices paid for impure doses of each drug from the Illicit Drug Reporting System, which surveys 1,000 regular injecting drug users across Australia in the middle of each year (see https: //ndarc.med.unsw.edu.au/project/illicit-drug-reporting-system-idrs). We use NSW respondents. Average purities come from forensic analyses of all packages weighing less than one gram from the Victoria Police Forensic Science Centre. 
Figure A2: Trends in prescription opioids in Australia and the United States

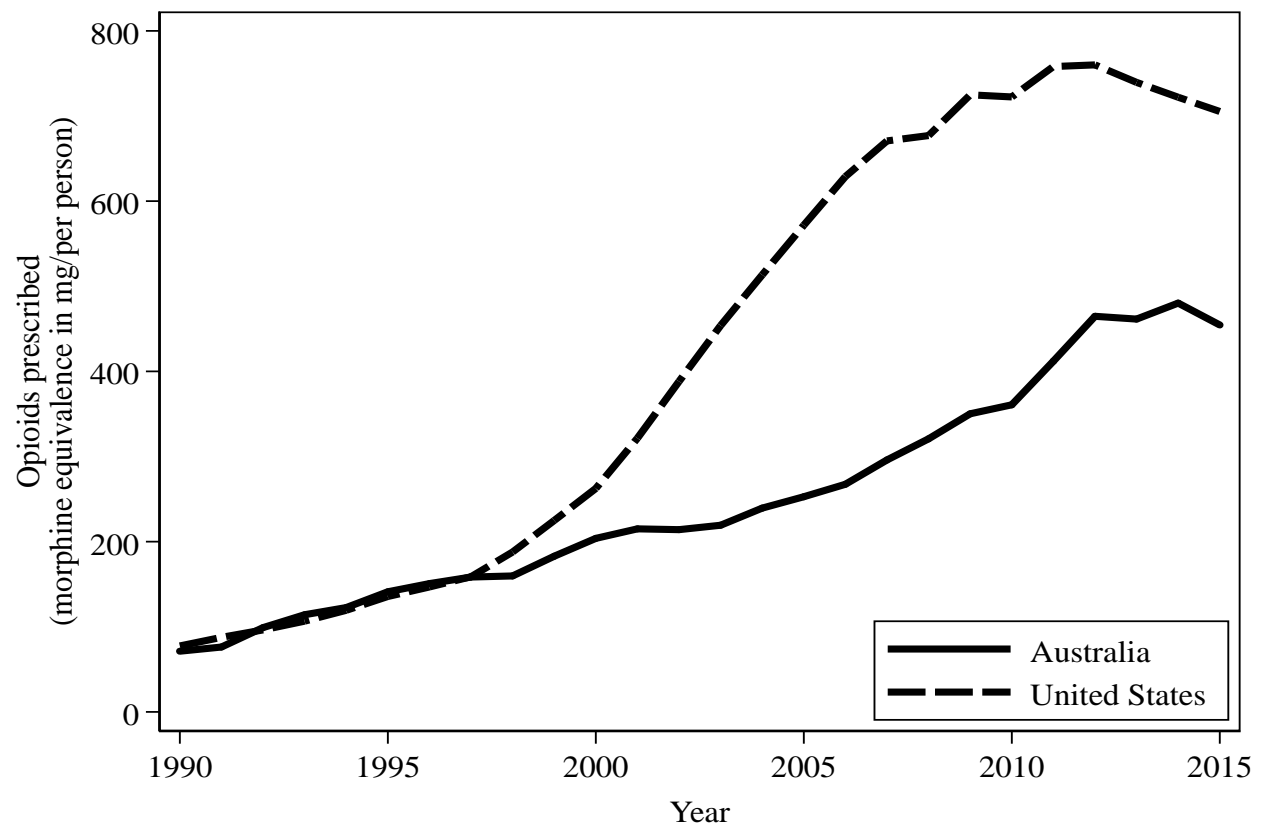

Notes: This figure plots estimates of the annual milligrams per person of opioids prescribed in both Australia and the United States from 1990 through 2015. Data was originally compiled from International Narcotics Control Board reports by the Pain \& Policy Studies Group at the University of Wisconsin. We obtained figures for Australia from a 2019 report, "Pharmaceutical opioids in Australia: A double-edged sword" available at http://nceta.flinders.edu.au/files/2415/4960/5275/ Pharmaceutical_opioids_in_Australia_A_double-edged_sword.pdf[Accessed 2 June 2020] and figures for the United States from https://www.hrw.org/report/2018/12/18/not-allowed-be-compassionate/ chronic-pain-overdose-crisis-and-unintended-harms-us[Accessed 2 June 2020]. All prescription amounts are adjusted to morphine-equivalent units based on the notion that different doses of different opioids may give a similar analgesic effect. 
Figure A3: Heroin prices in Australia and other countries, 1999

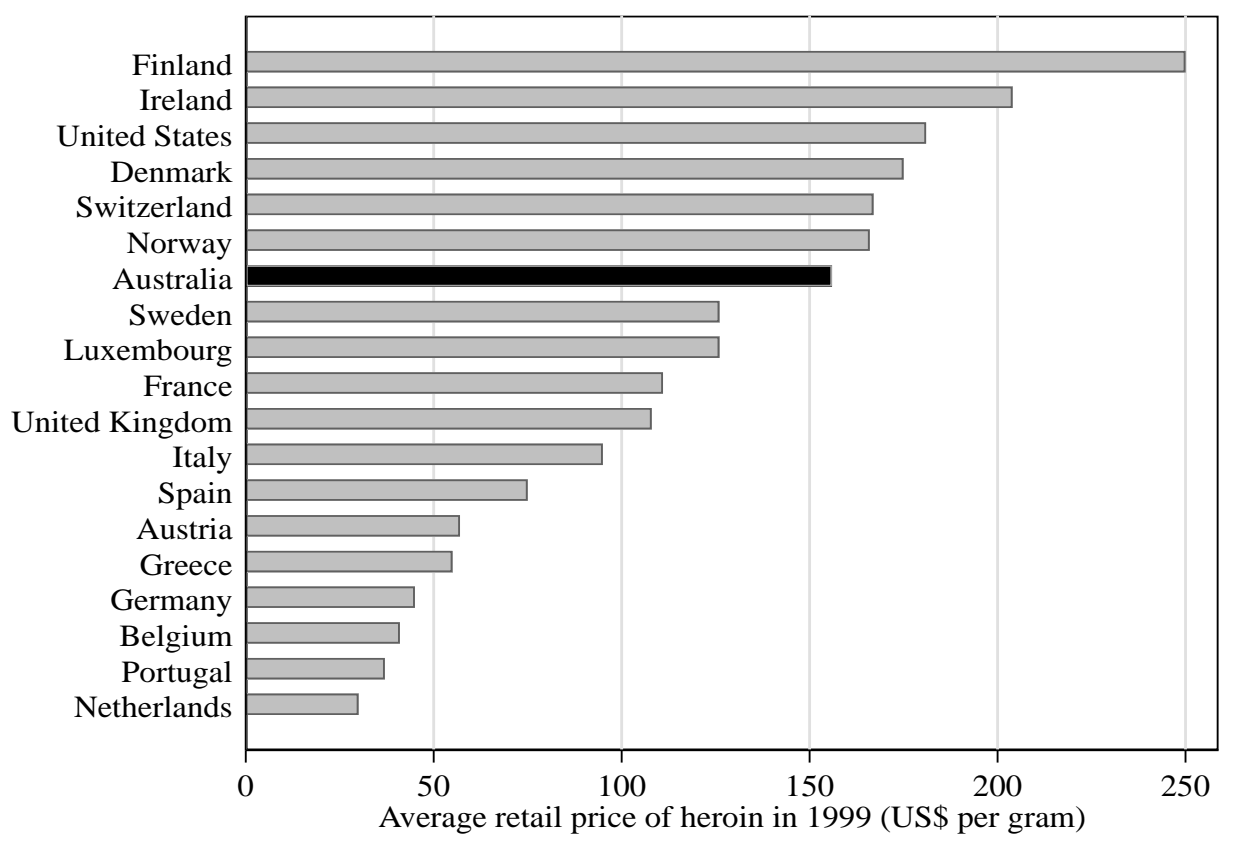

Notes: This compares heroin prices in Australia in 1999, the final year before the onset of the supply reduction there, to heroin prices in Europe and the US. Prices are in 1999 US dollars and are not adjusted for heroin purity. Australian data are the average prices paid for a gram of heroin from the Illicit Drug Reporting System (see https://ndarc.med.unsw.edu.au/project/ illicit-drug-reporting-system-idrs). The data for the other countries are from the United Nations Office of Drugs and Crime (see https://www.unodc.org/wdr2018/prelaunch/7.5_Standardized_prices_ of_cocaine_and_heroin_in_the_United_States_and_Western_Europe.xlsx; accessed 15 Nov 2020 ). 
Figure A4: Australian Federal Police activities and outcomes related to drug interdiction

(a) Funding for policing federal crimes

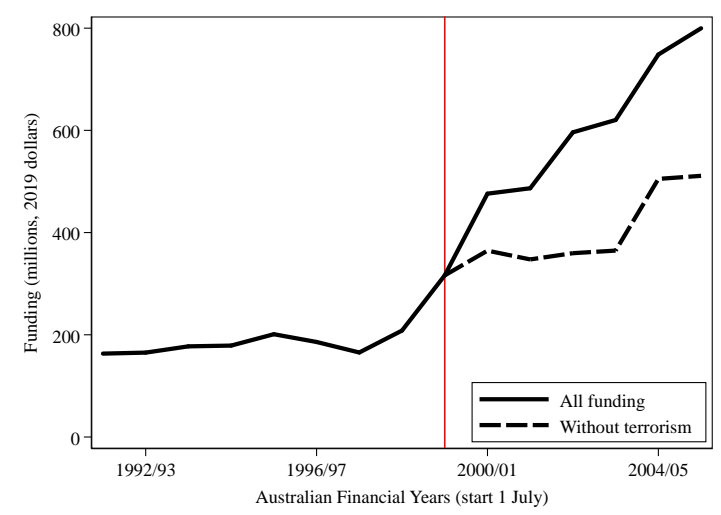

(c) Amount of heroin seized (kilograms)

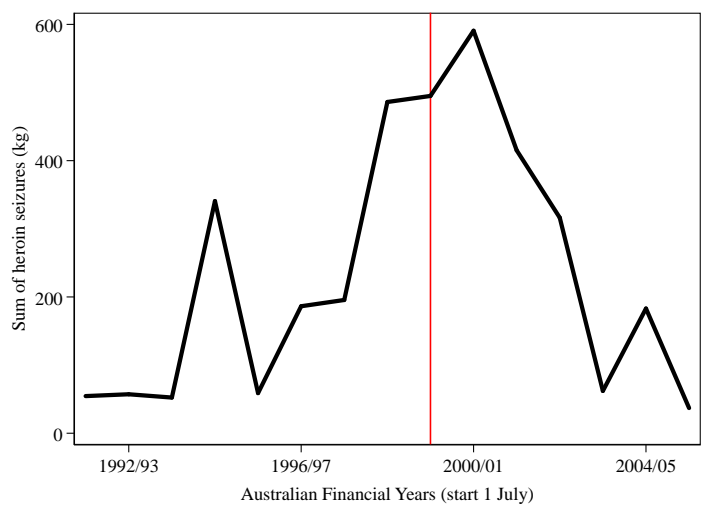

(b) International policing presence

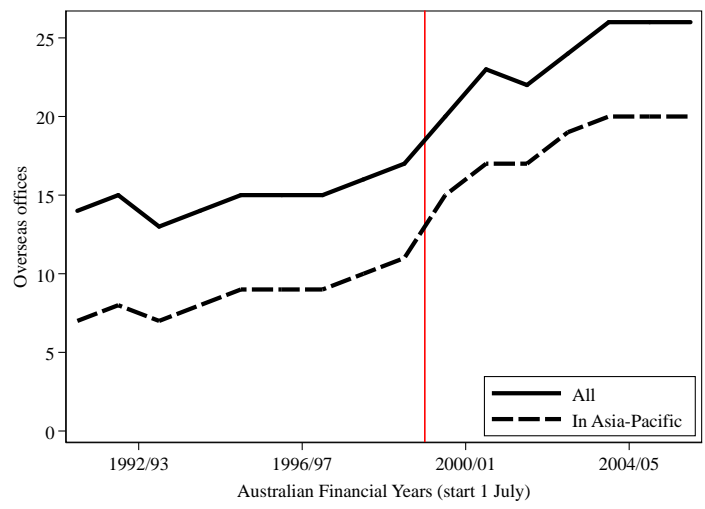

(d) Average weight per seizure (kilograms)

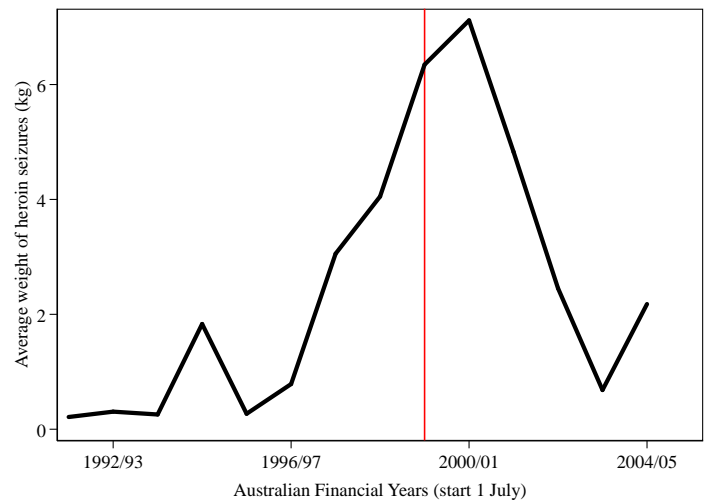

Notes: These figures are constructed from annual reports from the Australia Federal Police, the agency responsible for international drug interdiction. They are based on Australian financial years, which run from July 1 to June 30 of the following year. The vertical red lines show the 1999/2000 Financial Year, which is the last Australian Financial Year before the onset of the heroin supply reduction. Panel A shows the funding for policing federal crimes, which was primarily related to drug trafficking and organized crime until 2000/01, when the Australian Federal Police took on extra responsibilities related to terrorism. The amount of heroin seized and average weight of seizures are not adjusted for heroin purity, as that information is not provided in the annual reports. 
Figure A5: Measures of government services and labor market outcomes in New South Wales

(a) Police staffing

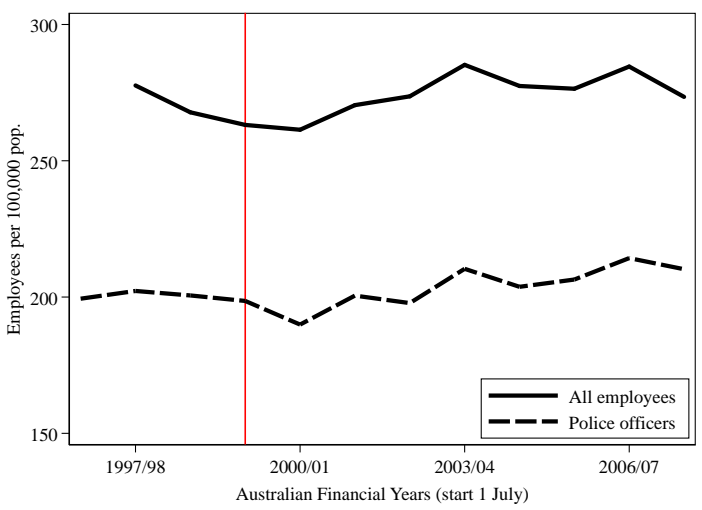

(c) Specialized mental health services

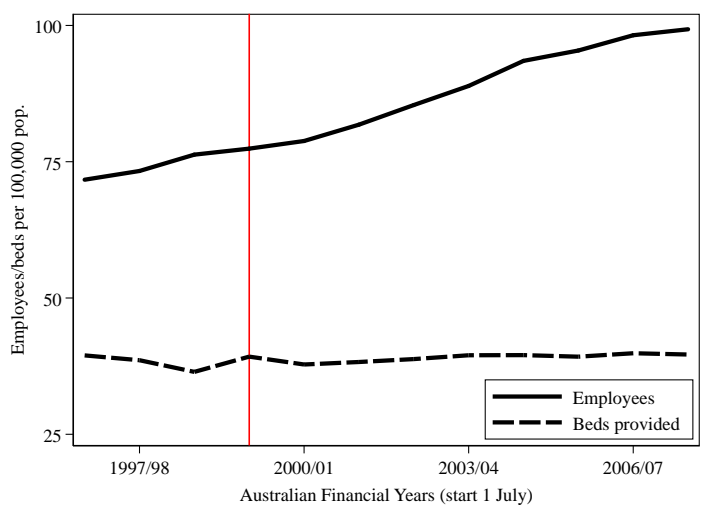

(e) Unemployment rate \& emp/pop. ratio

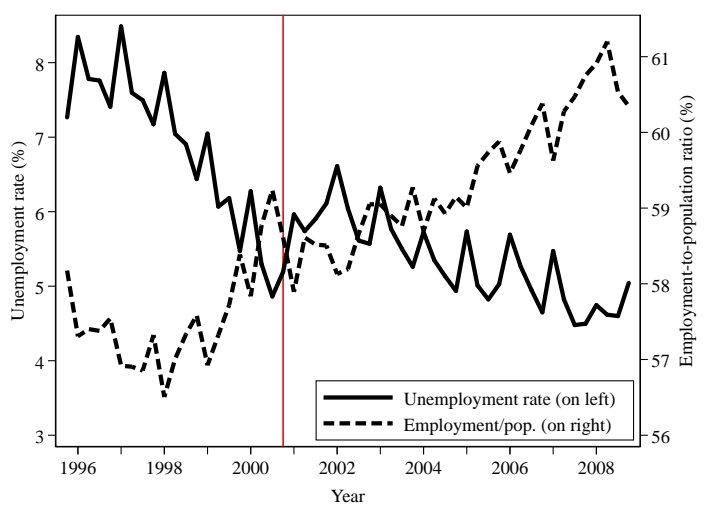

(b) Number of prisoners and prison capacity

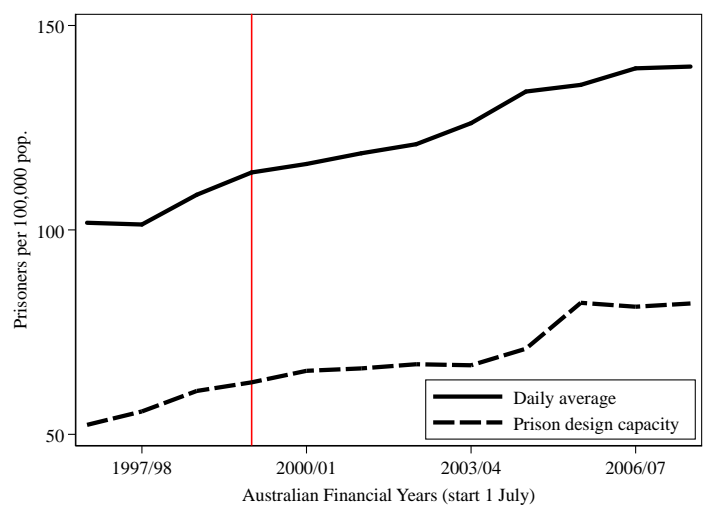

(d) Social insurance payments

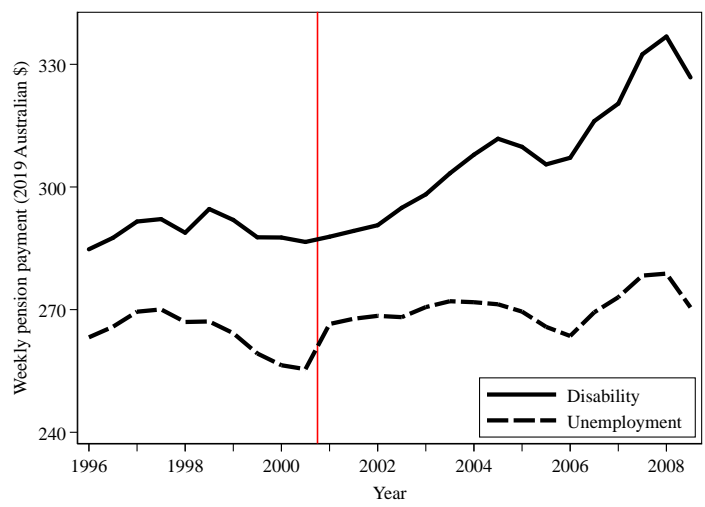

(f) Average weekly earnings

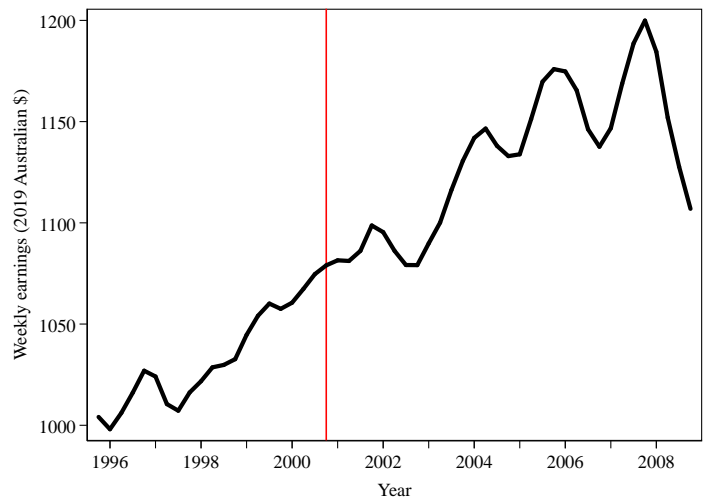

Notes: This figure plots various measures of government services and labor market activity in New South Wales from 1996 to 2008. Panels (a) to (c) use data from the Productivity Commission's Report on Government Services, which is an annual data collection on key service outcomes for the federal and state governments in Australia. Employee numbers are fulltime equivalent. Reports are available at: https: //www.pc.gov.au/research/ongoing/report-on-government-services[Accessed 10 May 2020]. Panel (d) reports the weekly payment rates for disability and unemployment benefits provided by the federal government. Rates are for single individuals aged 21+, and are converted to 2019 Australian dollars using the Consumer Price Index. They are available at: https://guides.dss.gov.au/guide-social-security-law/5/2/1[Accessed 10 May 2020]. Panel (e) shows the state's quarterly trend unemployment rate and employment/population ratio, and comes from Table 4 of the Australian Bureau of Statistics' 6202.0 Labour Force, Australia publication. Panel (f) shows trend quarterly average weekly earnings, and are converted to 2019 Australian dollars using the Consumer Price Index. The data come from Table 11A of Australian Bureau of Statistics' 6302.0 Average Weekly Earnings, Australia publication. The Australian Bureau of Statistics publications are available online at https://www.abs.gov.au/[Accessed 10 May 2020]. 
Figure A6: Severity of punishment for drug, violent and property offenses

(a) Opioid offenses

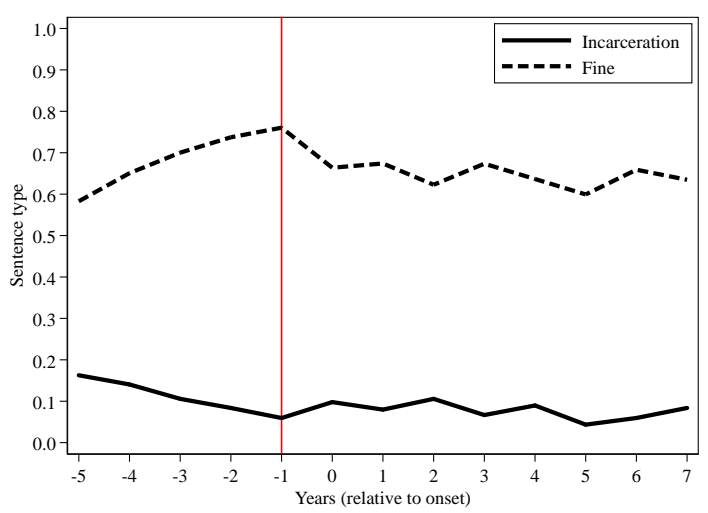

(c) Violent offenses

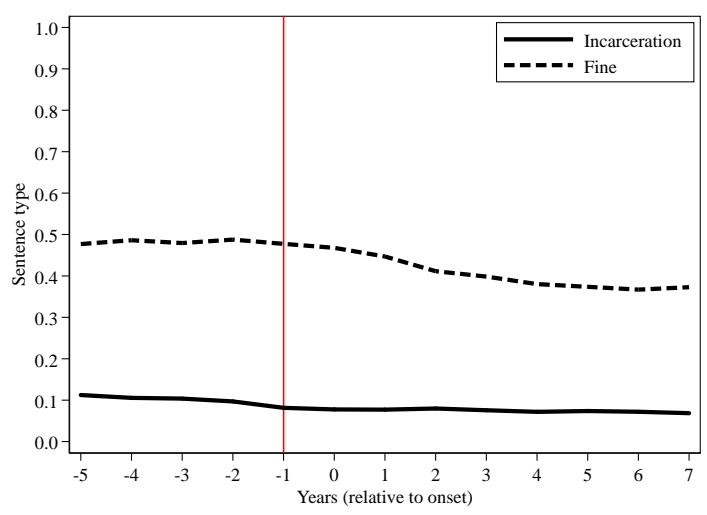

(e) Average length of incarceration sentences

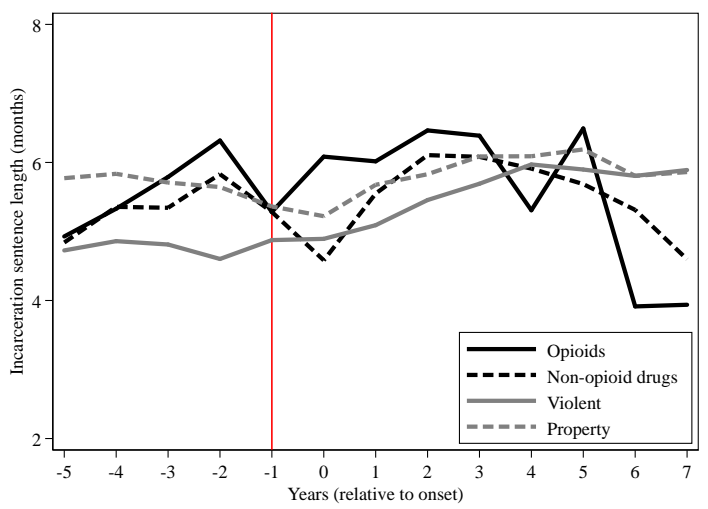

(b) Cocaine or methamphetamine offenses

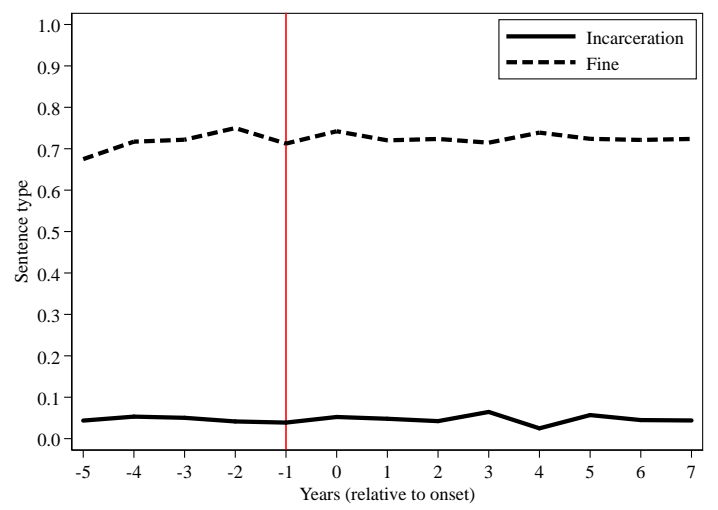

(d) Property offenses

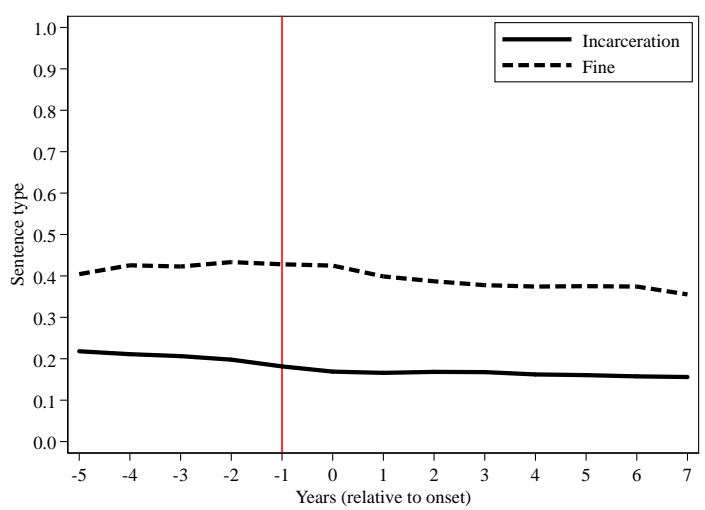

(f) Average amount of fine

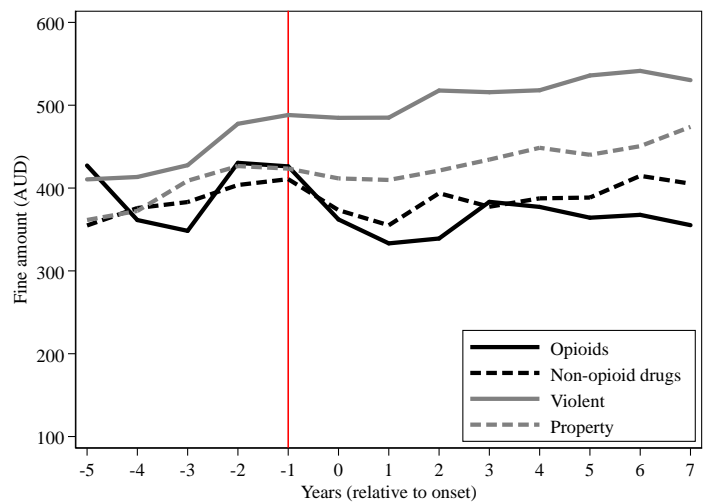

Notes: This figure plots trends in the type and severity of punishments imposed in NSW. Regression-adjusted average rates for three types of sanctions (incarceration or fine) are displayed in figures (a) through (d). Other sanctions not depicted include sanctions of home detention, suspended sentences, bonds, or community service. Regression-adjusted average sentence lengths or average fine amounts are shown in figures (e) and (f) for opioid drug offenses, non-opioid drug offenses (methamphatmine, cocaine, and other non-cannibis illicit drugs), violent offenses, and property offenses. To account for changes in offender characteristics during our analysis period that influence penalties, we adjust rates as follows: We estimate a model that includes an indicator variable for the sentence type (or incarceration sentence length) as the dependent variable using the court outcome data from the NSW Bureau of Crime Statistics and Research. As regressors we include indicators for years since the heron supply reduction; the number of prior charges for each type of drug offenses as well as property and violent offenses; the number and type of concurrent charges; and indicators for age (in years), gender and indigenous status. We add the coefficients associated with the year's since reduction indicator variables to the baseline period (1999-Q4 through 2000-Q3) average outcome to obtain regression-adjusted values that are not influenced by changes in defendant characteristics. 
Figure A7: Fraction of all NSW opioid-related outcomes accounted for by our sample

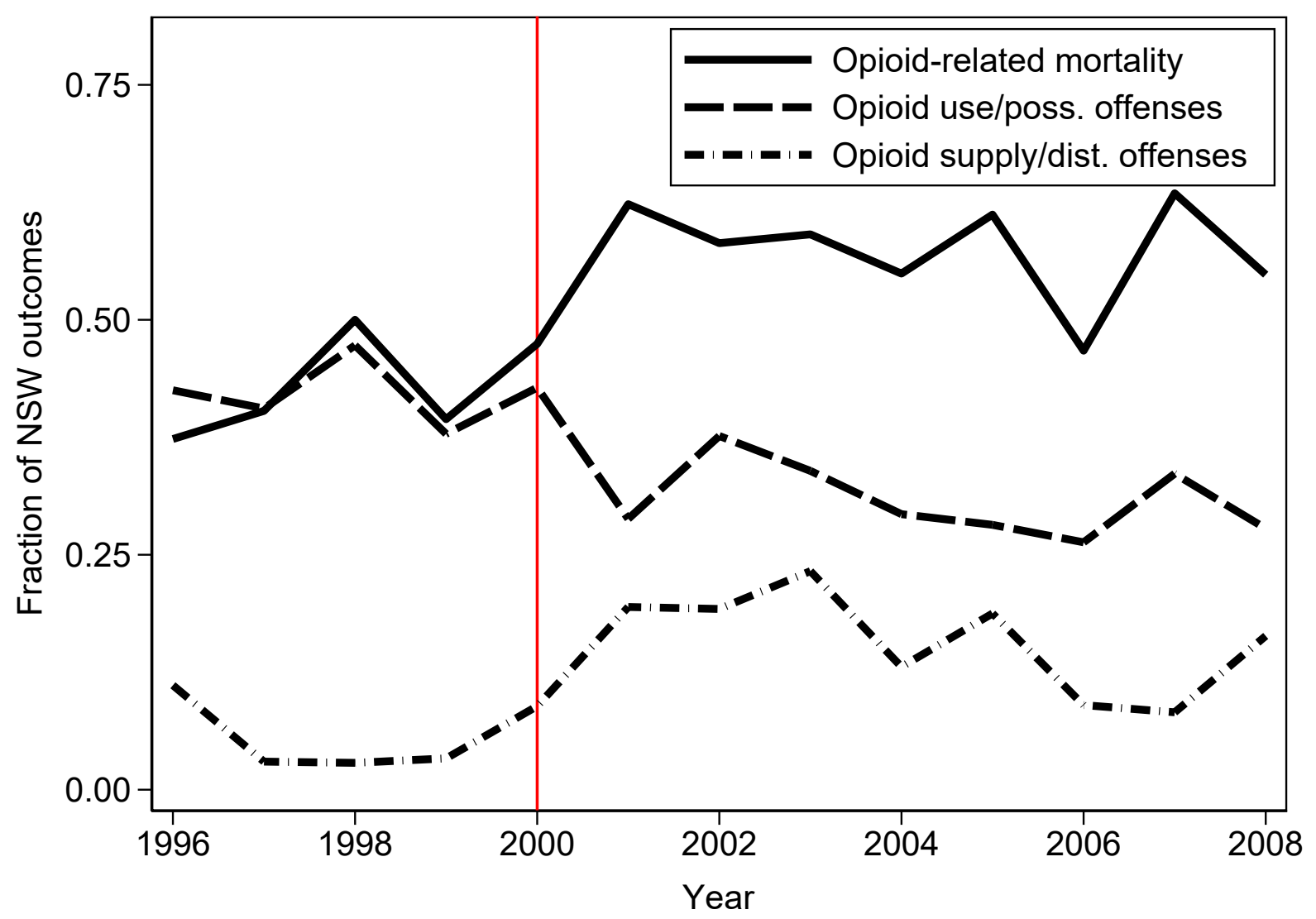

Notes: This figure shows the overall fraction of mortality and criminal charges in NSW that are attributed to our group of opioid users prior to the heroin supply reduction. To obtain counts opioid-related mortality for the NSW population, we use data provided by the Centre for Epidemiology and Evidence within the NSW Ministry of Health available at: www.healthstats.nsw.gov.au[Accessed 15 May 2020]. Counts of opioid-related criminal charges were obtained from the Reoffending Database provided by the NSW Bureau of Crime Statistics and Research. 
Figure A8: Estimates applied to overall NSW criminal charges

(a) Violent offenses

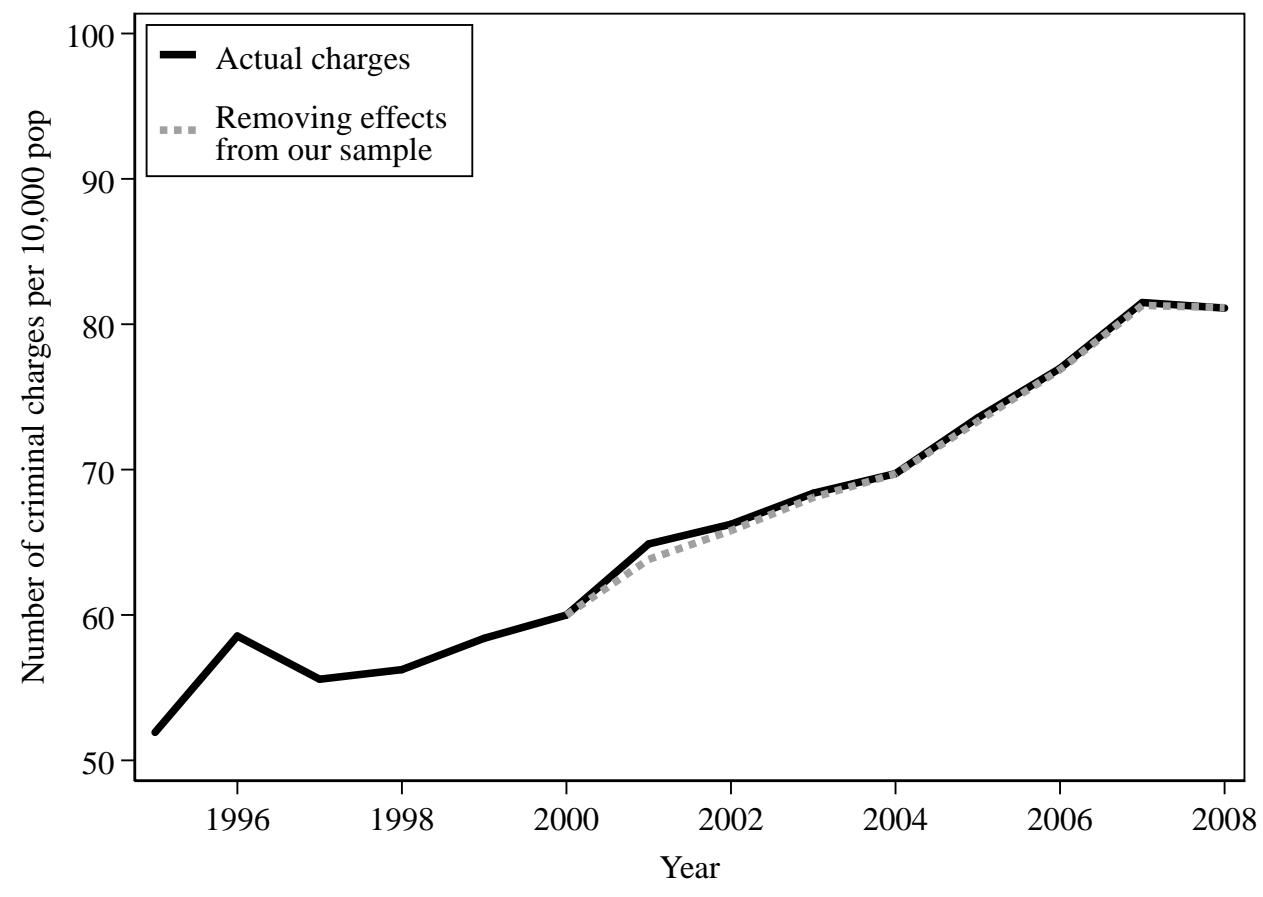

(b) Property offenses

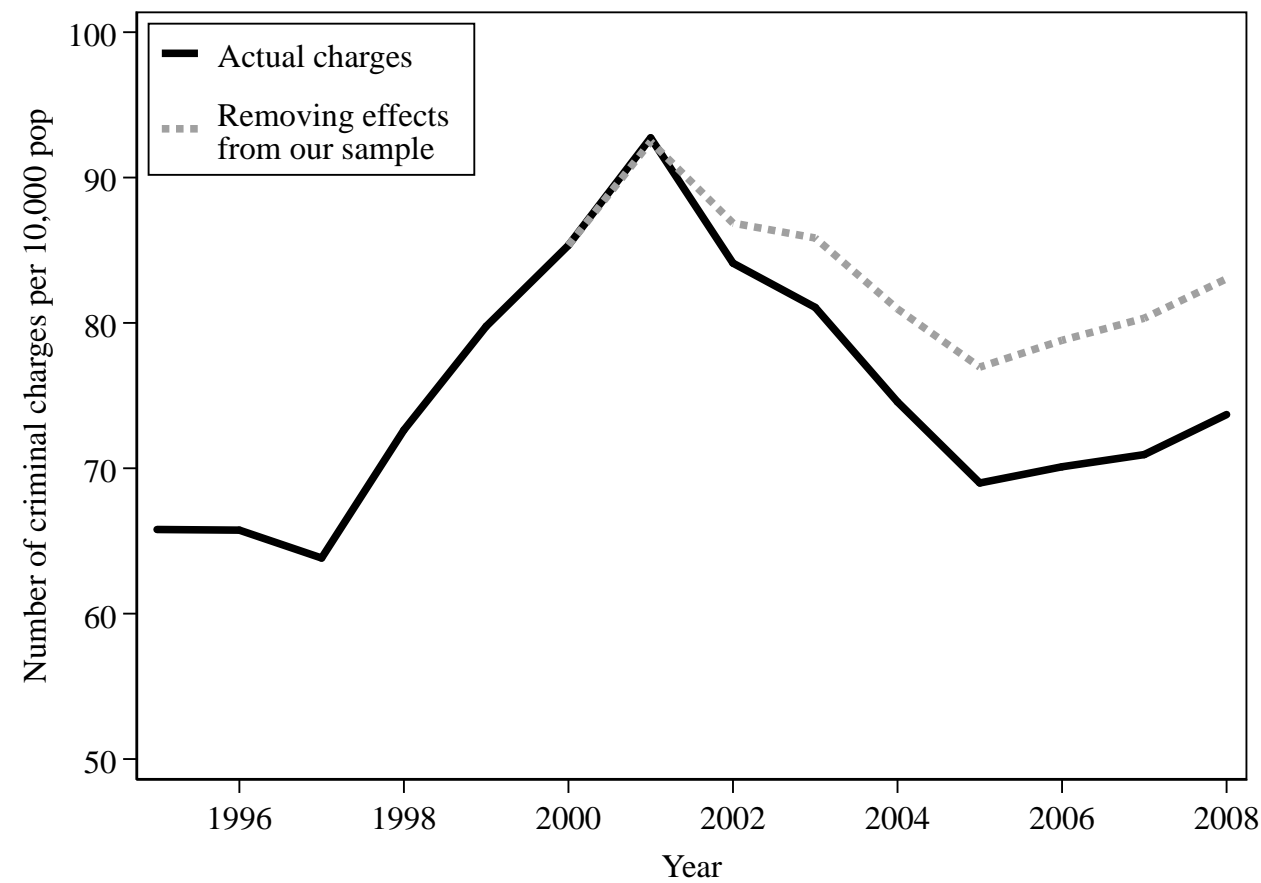

Notes: This figure shows the aggregate criminal charges per year per 10,000 population in NSW by year from 1995 through 2008 (solid black lines) along with a counterfactual path implied by removing the estimated effects of the heroin supply reduction on our sample of 27,487 opioid users (dashed gray lines) for violent offenses (a) and property offenses (b). The cumulative difference in the number of offenses between the actual and counterfactual scenarios imply 1534 more violent offenses from 2001 through 2008 (2.3 per 10,000 population) and 33,158 less total property offenses from 2001 through 2008 (-49 per 10,000 population). 
Table A1: Estimated changes in violent offending (per 1,000 individuals)

\begin{tabular}{|c|c|c|c|c|c|c|c|c|c|c|}
\hline & $\begin{array}{l}\text { Violent } \\
\text { offenses }\end{array}$ & Homicide & $\begin{array}{c}\text { Manslaughter/ } \\
\text { attempted } \\
\text { homicide }\end{array}$ & Assault & $\begin{array}{c}\text { Serious } \\
\text { assault } \\
\text { w/injury }\end{array}$ & $\begin{array}{c}\text { Serious } \\
\text { assault } \\
\text { no injury }\end{array}$ & $\begin{array}{l}\text { Common } \\
\text { asault }\end{array}$ & $\begin{array}{l}\text { Sexual } \\
\text { asault }\end{array}$ & $\begin{array}{c}\text { Harrass- } \\
\text { ment }\end{array}$ & $\begin{array}{l}\text { Other } \\
\text { violent }\end{array}$ \\
\hline & $(1)$ & $(2)$ & $(3)$ & $(4)$ & $(5)$ & $(6)$ & $(7)$ & $(8)$ & $(9)$ & $(10)$ \\
\hline \multicolumn{11}{|l|}{ Pre-event: } \\
\hline Years -5 to -2 & $\begin{array}{l}-5.33 \\
(4.35)\end{array}$ & $\begin{array}{c}0.079 \\
(0.12)\end{array}$ & $\begin{array}{l}-0.068 \\
(0.19)\end{array}$ & $\begin{array}{l}-4.42 \\
(3.61)\end{array}$ & $\begin{array}{l}-0.87 \\
(1.62)\end{array}$ & $\begin{array}{l}-2.81^{*} \\
(1.37)\end{array}$ & $\begin{array}{l}-5.62^{*} \\
(2.49)\end{array}$ & $\begin{array}{l}-0.60 \\
(0.85)\end{array}$ & $\begin{array}{c}0.82 \\
(1.10)\end{array}$ & $\begin{array}{l}-1.14 \\
(1.67)\end{array}$ \\
\hline \multicolumn{11}{|l|}{ Post-event: } \\
\hline Year 0 & $\begin{array}{c}26.3^{* *} \\
(5.27)\end{array}$ & $\begin{array}{l}0.85^{* *} \\
(0.27)\end{array}$ & $\begin{array}{c}0.13 \\
(0.30)\end{array}$ & $\begin{array}{c}21.6^{* *} \\
(4.33)\end{array}$ & $\begin{array}{l}9.62^{* *} \\
(2.04)\end{array}$ & $\begin{array}{c}2.98 \\
(1.59)\end{array}$ & $\begin{array}{l}14.7^{* *} \\
(2.85)\end{array}$ & $\begin{array}{l}-0.16 \\
(0.69)\end{array}$ & $\begin{array}{c}0.94 \\
(1.40)\end{array}$ & $\begin{array}{l}2.90 \\
(2.00)\end{array}$ \\
\hline Year 1 & $\begin{array}{l}10.9^{*} \\
(5.28)\end{array}$ & $\begin{array}{c}0.24 \\
(0.20)\end{array}$ & $\begin{array}{c}0.14 \\
(0.23)\end{array}$ & $\begin{array}{l}10.3^{*} \\
(4.45)\end{array}$ & $\begin{array}{l}6.92^{* *} \\
(2.10)\end{array}$ & $\begin{array}{c}1.07 \\
(1.60)\end{array}$ & $\begin{array}{l}8.01^{* *} \\
(2.87)\end{array}$ & $\begin{array}{l}-0.10 \\
(0.62)\end{array}$ & $\begin{array}{c}2.14 \\
(1.34)\end{array}$ & $\begin{array}{l}-1.78 \\
(1.89)\end{array}$ \\
\hline Years 2 to 7 & $\begin{array}{c}3.46 \\
(4.28)\end{array}$ & $\begin{array}{c}0.084 \\
(0.13)\end{array}$ & $\begin{array}{l}-0.0039 \\
(0.18)\end{array}$ & $\begin{array}{c}9.06^{*} \\
(3.54)\end{array}$ & $\begin{array}{l}7.13^{* *} \\
(1.60)\end{array}$ & $\begin{array}{c}0.43 \\
(1.30)\end{array}$ & $\begin{array}{l}6.52^{* *} \\
(2.30)\end{array}$ & $\begin{array}{l}-1.13^{*} \\
(0.49)\end{array}$ & $\begin{array}{c}2.06 \\
(1.24)\end{array}$ & $\begin{array}{l}-6.60^{* *} \\
(1.60)\end{array}$ \\
\hline $\begin{array}{l}\text { Treatment group } \\
\text { avg. in Year }-1\end{array}$ & 85.48 & 0.12 & 0.31 & 62.14 & 14.35 & 12.59 & 33.16 & 0.39 & 1.60 & 20.92 \\
\hline
\end{tabular}

${ }^{*} \mathrm{p}<0.05,{ }^{* *} \mathrm{p}<0.01$.

Notes: This table summarizes the effects of the heroin reduction for violent offending outcomes. We present estimated coefficients and standard errors for the treatment group by year indicator variables in the event study specification described by Eq (1) in Section 3, which are presented in Figure5 for four of the primary types of violent offending. The specifications use data from our treatment group of opioid users along with data from the control group of non-opioid drug offenders. The reference period is the 12 months before the onset of the heroin reduction in 2000 Q4, denoted as Year -1. All estimates are scaled to represent annual outcomes per 1,000 individuals. Standard errors are robust to arbitrary correlation within individuals over time, and when coefficients are averaged across multiple years the delta method is used to calculate standard errors. Each regression uses 2,439,641 observations. To help understand the relative size of the effects, we show the treatment group mean for each outcome variable in the reference period (Year -1). 
Table A2: Estimated changes in property offending (per 1,000 individuals)

\begin{tabular}{l}
$\begin{array}{l}\text { Property } \\
\text { offenses }\end{array}$ \\
\cline { 2 - 5 }
\end{tabular}


Table A3: Estimated changes in opioid treatment outcomes (per 1,000 individuals)

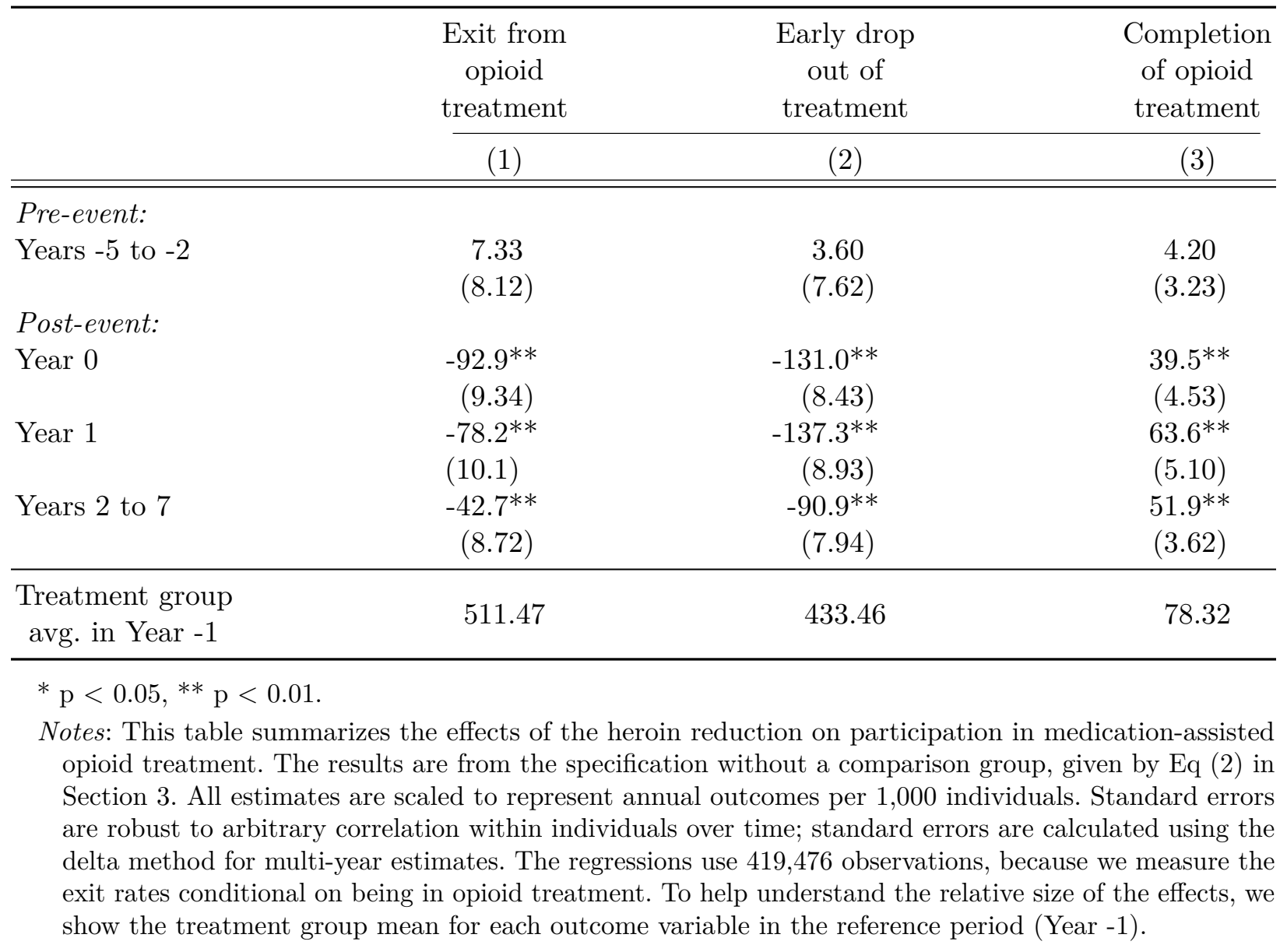


Table A4: Robustness to alternative specifications

\begin{tabular}{|c|c|c|c|c|c|}
\hline & No controls & $\begin{array}{l}\text { Add dem. controls } \\
\text { or indiv. FE }\end{array}$ & Add age controls & Include pre-trend & $\begin{array}{l}\text { Add controls } \\
\text { for unemp. rate }\end{array}$ \\
\hline & $(1)$ & $(2)$ & $(3)$ & $(4)$ & $(5)$ \\
\hline \multicolumn{6}{|l|}{ A. Mortality: } \\
\hline Years -5 to -2 & $\begin{array}{c}0.88 \\
(0.79)\end{array}$ & $\begin{array}{c}0.34 \\
(0.79)\end{array}$ & $\begin{array}{l}0.28 \\
(0.78)\end{array}$ & & $\begin{array}{c}0.71 \\
(1.96)\end{array}$ \\
\hline Year 0 & $\begin{array}{l}-1.95^{*} \\
(0.93)\end{array}$ & $\begin{array}{l}-1.86^{*} \\
(0.93)\end{array}$ & $\begin{array}{l}-1.83^{*} \\
(0.93)\end{array}$ & $\begin{array}{l}-2.17^{* *} \\
(0.73)\end{array}$ & $\begin{array}{l}-1.71 \\
(1.03)\end{array}$ \\
\hline Year 1 & $\begin{array}{l}-2.16^{*} \\
(0.91)\end{array}$ & $\begin{array}{l}-2.06^{*} \\
(0.91)\end{array}$ & $\begin{array}{l}-2.03^{*} \\
(0.91)\end{array}$ & $\begin{array}{l}-2.37^{* *} \\
(0.71)\end{array}$ & $\begin{array}{l}-1.91 \\
(1.02)\end{array}$ \\
\hline Years 2 to 7 & $\begin{array}{l}-2.06^{* *} \\
(0.72) \\
\end{array}$ & $\begin{array}{l}-1.96^{* *} \\
(0.72) \\
\end{array}$ & $\begin{array}{l}-2.63^{* *} \\
(0.73) \\
\end{array}$ & $\begin{array}{l}-2.98^{* *} \\
(0.47) \\
\end{array}$ & $\begin{array}{l}-2.71^{* *} \\
(0.80) \\
\end{array}$ \\
\hline \multicolumn{6}{|c|}{ B. Non-opioid drug use/possession: } \\
\hline Years -5 to -2 & $\begin{array}{c}1.95 \\
(1.24)\end{array}$ & $\begin{array}{c}1.34 \\
(1.29)\end{array}$ & $\begin{array}{l}1.06 \\
(1.30)\end{array}$ & & $\begin{array}{l}-2.20 \\
(3.37)\end{array}$ \\
\hline Year 0 & $\begin{array}{l}6.44^{* *} \\
(1.74)\end{array}$ & $\begin{array}{l}6.46^{* *} \\
(1.76)\end{array}$ & $\begin{array}{l}6.54^{* *} \\
(1.76)\end{array}$ & $\begin{array}{l}5.71^{* *} \\
(1.51)\end{array}$ & $\begin{array}{l}5.66^{* *} \\
(1.94)\end{array}$ \\
\hline Year 1 & $\begin{array}{c}3.78^{*} \\
(1.51)\end{array}$ & $\begin{array}{c}3.81^{*} \\
(1.53)\end{array}$ & $\begin{array}{l}3.98^{* *} \\
(1.54)\end{array}$ & $\begin{array}{c}3.16^{*} \\
(1.23)\end{array}$ & $\begin{array}{c}3.10 \\
(1.70)\end{array}$ \\
\hline Years 2 to 7 & $\begin{array}{l}4.11^{* *} \\
(1.21) \\
\end{array}$ & $\begin{array}{l}4.10^{* *} \\
(1.22) \\
\end{array}$ & $\begin{array}{l}4.43^{* *} \\
(1.28) \\
\end{array}$ & $\begin{array}{l}3.61^{* *} \\
(0.93) \\
\end{array}$ & $\begin{array}{l}4.98^{* *} \\
(1.42) \\
\end{array}$ \\
\hline \multicolumn{6}{|l|}{ C. Violent offenses: } \\
\hline$\overline{\text { Years }-5 \text { to }-2}$ & $\begin{array}{l}-2.54 \\
(4.30)\end{array}$ & $\begin{array}{l}-5.35 \\
(4.32)\end{array}$ & $\begin{array}{l}-5.33 \\
(4.35)\end{array}$ & & $\begin{array}{r}-4.41 \\
(10.7)\end{array}$ \\
\hline Year 0 & $\begin{array}{l}26.6^{* *} \\
(5.20)\end{array}$ & $\begin{array}{l}26.6^{* *} \\
(5.25)\end{array}$ & $\begin{array}{l}26.3^{* *} \\
(5.27)\end{array}$ & $\begin{array}{l}29.4^{* *} \\
(4.37)\end{array}$ & $\begin{array}{l}26.5^{* *} \\
(5.98)\end{array}$ \\
\hline Year 1 & $\begin{array}{l}11.8^{*} \\
(5.20)\end{array}$ & $\begin{array}{l}11.8^{*} \\
(5.24)\end{array}$ & $\begin{array}{l}10.9^{*} \\
(5.28)\end{array}$ & $\begin{array}{l}14.0^{* *} \\
(4.29)\end{array}$ & $\begin{array}{l}11.2 \\
(5.96)\end{array}$ \\
\hline Years 2 to 7 & $\begin{array}{c}5.43 \\
(4.05) \\
\end{array}$ & $\begin{array}{c}5.54 \\
(4.08) \\
\end{array}$ & $\begin{array}{c}3.46 \\
(4.28) \\
\end{array}$ & $\begin{array}{r}6.49^{*} \\
(3.01) \\
\end{array}$ & $\begin{array}{c}3.29 \\
(4.51) \\
\end{array}$ \\
\hline \multicolumn{6}{|l|}{ D. Property offenses: } \\
\hline Years -5 to -2 & $\begin{array}{l}-31.4^{* *} \\
(10.8)\end{array}$ & $\begin{array}{c}-5.20 \\
(10.7)\end{array}$ & $\begin{array}{c}12.4 \\
(10.8)\end{array}$ & & $\begin{array}{l}30.6 \\
(21.4)\end{array}$ \\
\hline Year 0 & $\begin{array}{c}24.9 \\
(13.4)\end{array}$ & $\begin{array}{c}20.5 \\
(13.5)\end{array}$ & $\begin{array}{r}6.50 \\
(13.5)\end{array}$ & $\begin{array}{c}-0.79 \\
(10.7)\end{array}$ & $\begin{array}{c}11.4 \\
(14.3)\end{array}$ \\
\hline Year 1 & $\begin{array}{l}-40.3^{* *} \\
(13.2)\end{array}$ & $\begin{array}{l}-44.8^{* *} \\
(13.4)\end{array}$ & $\begin{array}{l}-68.5^{* *} \\
(13.5)\end{array}$ & $\begin{array}{l}-75.7^{* *} \\
(10.3)\end{array}$ & $\begin{array}{l}-63.6^{* *} \\
(13.9)\end{array}$ \\
\hline Years 2 to 7 & $\begin{array}{c}-140.3^{* *} \\
(10.6) \\
\end{array}$ & $\begin{array}{c}-144.5^{* *} \\
(10.8) \\
\end{array}$ & $\begin{array}{c}-198.5^{* *} \\
(11.4) \\
\end{array}$ & $\begin{array}{c}-205.5^{* *} \\
(7.39) \\
\end{array}$ & $\begin{array}{c}-201.7^{* *} \\
(12.1) \\
\end{array}$ \\
\hline Dem. controls / ind. FE & & $\checkmark$ & $\checkmark$ & $\checkmark$ & $\checkmark$ \\
\hline Age controls & & & $\checkmark$ & $\checkmark$ & $\checkmark$ \\
\hline Pre-reduction trend & & & & $\checkmark$ & \\
\hline Unemp. rate controls & & & & & $\checkmark$ \\
\hline
\end{tabular}

$* \mathrm{p}<0.05,{ }^{*} * \mathrm{p}<0.01$. Notes: This table summarizes the estimated impacts of the heroin reduction across different specifications using data from our treatment and comparison groups. The reference period is the 12 months before the onset of the heroin reduction in 2000 Q4, denoted as Year - 1 . All estimates are scaled to represent annual outcomes per 1,000 individuals. Standard errors are robust to arbitrary correlation within individuals over time; standard errors are calculated using the delta method for multiyear estimates. Each regression uses 2,439,641 observations. Column (1) only includes indicator variables for time since the heroin supply reduction; Column (2) adds individual fixed effects (or controls for gender and indigenous status when mortality is the outcome); Column (3) adds a complete set of age fixed (making it equivalent to Eq (1)); Column (4) replaces the pre-reduction year indicator variables with a linear trend; and Column (5) adds controls for unemployment rates in NSW interacted with treatment group status to allow for differential labor market effects for the treatment and comparison groups. 
Table A5: Robustness to alternative sample definitions for comparison group

\begin{tabular}{|c|c|c|c|c|c|}
\hline & Main sample & $\begin{array}{c}\text { No } \\
\text { comparison } \\
\text { group }\end{array}$ & $\begin{array}{c}\text { No } \\
\text { comparison } \\
\text { group } \\
\mathrm{w} / \text { pre trend }\end{array}$ & $\begin{array}{l}\text { Comparison } \\
\text { group: } \\
\text { Non-opioid drug } \\
\text { property } \\
\text { and violent } \\
\text { offenders }\end{array}$ & $\begin{array}{l}\text { Excl. if died } \\
\text { or potentially } \\
\text { moved out } \\
\text { of NSW }\end{array}$ \\
\hline & $(1)$ & $(2)$ & (3) & $(4)$ & (5) \\
\hline \multicolumn{6}{|l|}{ A. Mortality: } \\
\hline$\overline{\text { Years }-5 \text { to }-2}$ & $\begin{array}{c}0.28 \\
(0.78)\end{array}$ & $\begin{array}{c}0.67 \\
(0.69)\end{array}$ & & $\begin{array}{l}-0.15 \\
(0.71)\end{array}$ & \\
\hline Year 0 & $\begin{array}{l}-1.83^{*} \\
(0.93)\end{array}$ & $\begin{array}{l}-1.41 \\
(0.80)\end{array}$ & $\begin{array}{l}-2.41^{* *} \\
(0.87)\end{array}$ & $\begin{array}{l}-1.11 \\
(0.83)\end{array}$ & \\
\hline Year 1 & $\begin{array}{l}-2.03^{*} \\
(0.91)\end{array}$ & $\begin{array}{l}-2.29^{* *} \\
(0.79)\end{array}$ & $\begin{array}{l}-3.44^{* *} \\
(1.02)\end{array}$ & $\begin{array}{l}-1.78^{*} \\
(0.82)\end{array}$ & \\
\hline Years 2 to 7 & $\begin{array}{l}-2.63^{* *} \\
(0.73) \\
\end{array}$ & $\begin{array}{l}-3.69^{* *} \\
(0.67) \\
\end{array}$ & $\begin{array}{l}-5.33^{* *} \\
(1.57) \\
\end{array}$ & $\begin{array}{l}-1.65^{*} \\
(0.67) \\
\end{array}$ & \\
\hline $\begin{array}{l}\text { Treatment group } \\
\text { avg. in Year -1 }\end{array}$ & 8.92 & 8.92 & 8.92 & 8.92 & \\
\hline \multicolumn{6}{|c|}{ B. Non-opioid drug use/possession: } \\
\hline Years -5 to -2 & $\begin{array}{c}1.06 \\
(1.30)\end{array}$ & $\begin{array}{l}-1.76 \\
(1.92)\end{array}$ & & $\begin{array}{l}1.06 \\
(0.86)\end{array}$ & $\begin{array}{c}2.14 \\
(1.57)\end{array}$ \\
\hline Year 0 & $\begin{array}{l}6.54^{* *} \\
(1.76)\end{array}$ & $\begin{array}{l}8.58^{* *} \\
(1.48)\end{array}$ & $\begin{array}{l}6.91^{* *} \\
(1.28)\end{array}$ & $\begin{array}{l}6.94^{* *} \\
(1.26)\end{array}$ & $\begin{array}{l}8.26^{* *} \\
(2.14)\end{array}$ \\
\hline Year 1 & $\begin{array}{l}3.98^{* *} \\
(1.54)\end{array}$ & $\begin{array}{c}2.39 \\
(1.91)\end{array}$ & $\begin{array}{l}-0.23 \\
(1.29)\end{array}$ & $\begin{aligned} 2.15^{*} \\
(1.07)\end{aligned}$ & $\begin{array}{l}4.98^{* *} \\
(1.87)\end{array}$ \\
\hline Years 2 to 7 & $\begin{array}{l}4.43^{* *} \\
(1.28) \\
\end{array}$ & $\begin{array}{c}4.59 \\
(4.20) \\
\end{array}$ & $\begin{array}{l}-1.34 \\
(1.93)\end{array}$ & $\begin{array}{l}2.41^{* *} \\
(0.87)\end{array}$ & $\begin{array}{l}5.41^{* *} \\
(1.53)\end{array}$ \\
\hline $\begin{array}{l}\text { Treatment group } \\
\text { avg. in Year -1 }\end{array}$ & 8.64 & 8.64 & 8.64 & 8.64 & 9.53 \\
\hline \multicolumn{6}{|l|}{ C. Violent offenses: } \\
\hline 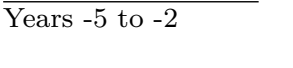 & $\begin{array}{l}-5.33 \\
(4.35)\end{array}$ & $\begin{array}{l}7.49 \\
(6.15)\end{array}$ & & $\begin{array}{c}-15.9^{* *} \\
(3.15)\end{array}$ & $\begin{array}{l}-4.22 \\
(5.21)\end{array}$ \\
\hline Year 0 & $\begin{array}{l}26.3^{* *} \\
(5.27)\end{array}$ & $\begin{array}{l}15.4^{* *} \\
(4.56)\end{array}$ & $\begin{array}{c}20.2^{* *} \\
(3.90)\end{array}$ & $\begin{array}{c}23.7^{* *} \\
(4.05)\end{array}$ & $\begin{array}{l}29.1^{* *} \\
(6.41)\end{array}$ \\
\hline Year 1 & $\begin{array}{l}10.9^{*} \\
(5.28)\end{array}$ & $\begin{array}{l}-7.42 \\
(6.20)\end{array}$ & $\begin{array}{c}0.72 \\
(4.42)\end{array}$ & $\begin{array}{r}9.94^{*} \\
(3.99)\end{array}$ & $\begin{array}{l}13.0^{*} \\
(6.44)\end{array}$ \\
\hline Years 2 to 7 & $\begin{array}{c}3.46 \\
(4.28) \\
\end{array}$ & $\begin{array}{l}-35.0^{* *} \\
(13.1)\end{array}$ & $\begin{array}{r}-15.2^{*} \\
(6.34)\end{array}$ & $\begin{array}{c}6.21^{*} \\
(3.11)\end{array}$ & $\begin{array}{c}3.80 \\
(5.14) \\
\end{array}$ \\
\hline $\begin{array}{l}\text { Treatment group } \\
\text { avg. in Year }-1\end{array}$ & 85.48 & 85.48 & 85.48 & 85.48 & 97.80 \\
\hline \multicolumn{6}{|l|}{ D. Property offenses: } \\
\hline$\overline{\text { Years }-5 \text { to }-2}$ & $\begin{array}{c}12.4 \\
(10.8)\end{array}$ & $\begin{array}{l}-38.7^{*} \\
(17.3)\end{array}$ & & $\begin{array}{r}-1.37 \\
(10.2)\end{array}$ & $\begin{array}{c}-1.76 \\
(13.6)\end{array}$ \\
\hline Year 0 & $\begin{array}{r}6.50 \\
(13.5)\end{array}$ & $\begin{array}{l}43.1^{* *} \\
(14.5)\end{array}$ & $\begin{array}{l}41.0^{* *} \\
(13.1)\end{array}$ & $\begin{array}{c}13.0 \\
(12.9)\end{array}$ & $\begin{array}{c}13.6 \\
(17.0)\end{array}$ \\
\hline Year 1 & $\begin{array}{l}-68.5^{* *} \\
(13.5)\end{array}$ & $\begin{array}{l}-18.4 \\
(18.3)\end{array}$ & $\begin{array}{l}-30.7^{*} \\
(15.2)\end{array}$ & $\begin{array}{l}-57.8^{* *} \\
(12.8)\end{array}$ & $\begin{array}{l}-67.3^{* *} \\
(16.9)\end{array}$ \\
\hline Years 2 to 7 & $\begin{array}{c}-198.5^{* *} \\
(11.4)\end{array}$ & $\begin{array}{l}-91.6^{* *} \\
(33.9)\end{array}$ & $\begin{array}{c}-139.4^{* *} \\
(21.8)\end{array}$ & $\begin{array}{c}-180.2^{* *} \\
(10.5)\end{array}$ & $\begin{array}{c}-212.5^{* *} \\
(14.1)\end{array}$ \\
\hline $\begin{array}{l}\text { Treatment group } \\
\text { avg. in Year }-1\end{array}$ & 365.23 & 365.23 & 365.23 & 365.23 & 425.41 \\
\hline No. of opioid users: & 27,467 & 27,467 & 27,467 & 27,467 & 20,036 \\
\hline No. in control group: & 25,745 & 0 & 0 & 134,219 & 20,236 \\
\hline
\end{tabular}

${ }^{*} \mathrm{p}<0.05,{ }^{* *} \mathrm{p}<0.01$. Notes: This table summarizes estimated impacts of the heroin reduction across several alternative definitions of our comparison group. Each estimate is based on Eq (1); see Table 2 notes for details. Column (1) reproduces estimates from Table 2; Column (2) presents results for a specification without a comparison group; Column (3) adds a pre-shortage linear trend to the specification in Column (2); Column (4) broadens the control group to include non-drug offenders charged with a property or violent crime prior to the supply reduction; and, Column (5) excludes individuals who die or who do not appear in any administrative data source after 2005 to assess concerns about differential migration. 
Table A6: Alternative definitions of treatment group

\begin{tabular}{|c|c|c|c|}
\hline & Main sample & $\begin{array}{l}\text { Treatment } \\
\text { group: } \\
\text { pre-shortage } \\
\text { offense }\end{array}$ & $\begin{array}{c}\text { Treatment } \\
\text { group: } \\
\text { pre-shortage } \\
\text { opioid } \\
\text { offense }\end{array}$ \\
\hline & $(1)$ & $(2)$ & $(3)$ \\
\hline \multicolumn{4}{|l|}{ A. Mortality: } \\
\hline Years -5 to -2 & $\begin{array}{l}0.28 \\
(0.78)\end{array}$ & $\begin{array}{l}-0.60 \\
(0.99)\end{array}$ & $\begin{array}{c}0.92 \\
(1.61)\end{array}$ \\
\hline Year 0 & $\begin{array}{l}-1.83^{*} \\
(0.93)\end{array}$ & $\begin{array}{l}-2.10 \\
(1.17)\end{array}$ & $\begin{array}{l}-3.74^{*} \\
(1.65)\end{array}$ \\
\hline Year 1 & $\begin{array}{l}-2.03^{*} \\
(0.91)\end{array}$ & $\begin{array}{l}-2.70^{*} \\
(1.14)\end{array}$ & $\begin{array}{l}-4.58^{* *} \\
(1.60)\end{array}$ \\
\hline Years 2 to 7 & $\begin{array}{l}-2.63^{* *} \\
(0.73)\end{array}$ & $\begin{array}{l}-2.64^{* *} \\
(0.92)\end{array}$ & $\begin{array}{l}-4.02^{* *} \\
(1.35)\end{array}$ \\
\hline $\begin{array}{l}\text { Treatment group } \\
\text { avg. in Year }-1\end{array}$ & 8.92 & 9.76 & 9.78 \\
\hline \multicolumn{4}{|c|}{ B. Non-opioid drug use/possession: } \\
\hline Years -5 to -2 & $\begin{array}{c}1.06 \\
(1.30)\end{array}$ & $\begin{array}{c}0.93 \\
(1.69)\end{array}$ & $\begin{array}{c}1.80 \\
(3.23)\end{array}$ \\
\hline Year 0 & $\begin{array}{l}6.54^{* *} \\
(1.76)\end{array}$ & $\begin{array}{l}10.9^{* *} \\
(2.35)\end{array}$ & $\begin{array}{l}10.2^{* *} \\
(3.90)\end{array}$ \\
\hline Year 1 & $\begin{array}{l}3.98^{* *} \\
(1.54)\end{array}$ & $\begin{array}{l}4.37^{*} \\
(2.02)\end{array}$ & $\begin{array}{l}-3.74 \\
(3.39)\end{array}$ \\
\hline Years 2 to 7 & $\begin{array}{c}4.43^{* *} \\
(1.28) \\
\end{array}$ & $\begin{array}{c}4.59^{* *} \\
(1.63) \\
\end{array}$ & $\begin{array}{l}-4.34 \\
(2.89) \\
\end{array}$ \\
\hline $\begin{array}{l}\text { Treatment group } \\
\text { avg. in Year }-1 \\
\end{array}$ & 8.64 & 14.29 & 23.65 \\
\hline \multicolumn{4}{|l|}{ C. Violent offenses: } \\
\hline$\overline{\text { Years }-5 \text { to }-2}$ & $\begin{array}{l}-5.33 \\
(4.35)\end{array}$ & $\begin{array}{l}-9.49 \\
(5.70)\end{array}$ & $\begin{array}{l}8.02 \\
(8.04)\end{array}$ \\
\hline Year 0 & $\begin{array}{c}26.3^{* *} \\
(5.27)\end{array}$ & $\begin{array}{c}35.3^{* *} \\
(7.12)\end{array}$ & $\begin{array}{c}42.7^{* *} \\
(9.56)\end{array}$ \\
\hline Year 1 & $\begin{array}{l}10.9^{*} \\
(5.28)\end{array}$ & $\begin{array}{l}11.7 \\
(7.08)\end{array}$ & $\begin{array}{c}9.99 \\
(8.98)\end{array}$ \\
\hline Years 2 to 7 & $\begin{array}{c}3.46 \\
(4.28) \\
\end{array}$ & $\begin{array}{l}-0.97 \\
(5.54)\end{array}$ & $\begin{array}{c}5.92 \\
(7.06)\end{array}$ \\
\hline $\begin{array}{l}\text { Treatment group } \\
\text { avg. in Year }-1\end{array}$ & 85.48 & 141.34 & 121.10 \\
\hline \multicolumn{4}{|l|}{ D. Property offenses: } \\
\hline Years -5 to -2 & $\begin{array}{c}12.4 \\
(10.8)\end{array}$ & $\begin{array}{r}-4.17 \\
(17.0)\end{array}$ & $\begin{array}{c}41.3 \\
(24.6)\end{array}$ \\
\hline Year 0 & $\begin{array}{r}6.50 \\
(13.5)\end{array}$ & $\begin{array}{r}7.46 \\
(21.1)\end{array}$ & $\begin{array}{c}14.9 \\
(48.4)\end{array}$ \\
\hline Year 1 & $\begin{array}{l}-68.5^{* *} \\
(13.5)\end{array}$ & $\begin{array}{l}-93.1^{* *} \\
(21.1)\end{array}$ & $\begin{array}{c}-124.7^{* *} \\
(30.3)\end{array}$ \\
\hline Years 2 to 7 & $\begin{array}{c}-198.5^{* *} \\
(11.4) \\
\end{array}$ & $\begin{array}{c}-272.4^{* *} \\
(16.9) \\
\end{array}$ & $\begin{array}{c}-347.5^{* *} \\
(23.7) \\
\end{array}$ \\
\hline $\begin{array}{l}\text { Treatment group } \\
\text { avg. in Year }-1\end{array}$ & 365.23 & 603.90 & 697.89 \\
\hline No. of opioid users: & 27,467 & 16,609 & 7,254 \\
\hline No. in control group: & 25,745 & 25,745 & 25,745 \\
\hline
\end{tabular}

$* \mathrm{p}<0.05, * * \mathrm{p}<0.01$. Notes: This table summarizes estimated impacts of the heroin reduction across two alternative definitions of our treatment group. Each estimate is based on Eq (1); see Table 2 notes for details. Column (1) reproduces estimates from Table 2; Column (5) restricts our treatment group to those with a criminal offense prior to the heroin supply reduction; and, Column (6) redefines our treatment group using opioid drug offences rather than opioid treatment program participation. 
Table B1: Studies of the effects of the Australian heroin supply reduction

\begin{tabular}{|c|c|c|c|c|c|c|}
\hline Focus & Study & Outcomes & Follow up & Data & Methods & Key findings \\
\hline \multicolumn{7}{|c|}{ A. Studies that primarily focus on heroin (or opioid) outcomes } \\
\hline $\begin{array}{l}\text { Heroin \& } \\
\text { opioid } \\
\text { outcomes }\end{array}$ & $\begin{array}{l}\text { Smithson M., McFadden } \\
\text { M., and Mwesigye, S.-E. } \\
\text { 2005. "Impact of Federal } \\
\text { drug law enforcement on } \\
\text { the supply of heroin in } \\
\text { Australia. Addiction, 100: } \\
1110-20 \text {. }\end{array}$ & $\begin{array}{l}\text { - Street-level } \\
\text { heroin purity } \\
\text { - Federal heroin } \\
\text { seizures }\end{array}$ & 2.8 years & $\begin{array}{l}\text { - Territory- and } \\
\text { national-level daily } \\
\text { administrative data }\end{array}$ & $\begin{array}{l}\text { Time-series } \\
\text { analysis }\end{array}$ & $\begin{array}{l}\text { - Large decrease in heroin } \\
\text { purity in } 2001 \\
\text { - Increase in heroin seizures } \\
\text { one year before a decrease in } \\
\text { heroin purity }\end{array}$ \\
\hline $\begin{array}{l}\text { Heroin \& } \\
\text { opioid } \\
\text { outcomes }\end{array}$ & $\begin{array}{l}\text { Day, C., Degenhardt, L., } \\
\text { and Hall, W. } 2006 . \\
\text { "Documenting the heroin } \\
\text { shortage in New South } \\
\text { Wales." Drug and Alcohol } \\
\text { Review, 25: 297-305. }\end{array}$ & $\begin{array}{l}\text { - Self-reported } \\
\text { heroin } \\
\text { accessibility } \\
\text { - Heroin price } \\
\text { and purity }\end{array}$ & $\begin{array}{l}3.5-5 \\
\text { years }\end{array}$ & $\begin{array}{l}\text { - Self-reports from } \\
\text { injecting drug } \\
\text { users (annual } \\
\text { cross-sections, } \\
\text { convenience } \\
\text { sampling) } \\
\text { - State-level } \\
\text { quarterly data on } \\
\text { heroin seizures } \\
\text { - Interviews with } \\
\text { health/law } \\
\text { enforcement } \\
\text { professionals }\end{array}$ & Descriptive & $\begin{array}{l}\text { - Clear reduction in heroin } \\
\text { supply, increase in heroin } \\
\text { price and decrease in heroin } \\
\text { purity in NSW in early } 2001 \\
\text { - Slight rebound in measures } \\
\text { after } 2001 \text { but lasting } \\
\text { reductions in heroin supply }\end{array}$ \\
\hline $\begin{array}{l}\text { Heroin \& } \\
\text { opioid } \\
\text { outcomes }\end{array}$ & $\begin{array}{l}\text { Day, C., Degenhardt, L., } \\
\text { and Hall, W. } 2006 . \\
\text { "Changes in the initiation } \\
\text { of heroin use after a } \\
\text { reduction in heroin } \\
\text { supply." Drug and Alcohol } \\
\text { Review, 25: 307-13. }\end{array}$ & $\begin{array}{l}\text {-Age of survey } \\
\text { respondent } \\
\text { - Age of initial } \\
\text { heroin use }\end{array}$ & 4 years & $\begin{array}{l}\text { - Self-reports from } \\
\text { injecting drug } \\
\text { users (annual } \\
\text { cross-sections, } \\
\text { convenience } \\
\text { sampling) }\end{array}$ & $\begin{array}{l}\text { Time- } \\
\text { series } \\
\text { analysis }\end{array}$ & $\begin{array}{l}\text { - Estimate } 2,745-10,560 \\
\text { young people avoided } \\
\text { initiation into heroin use } \\
\text { during } 2001 \text { due to reduced } \\
\text { heroin supply } \\
\text { - Increase in amphetamine } \\
\text { injecting but "unclear to what } \\
\text { extent any reduction in } \\
\text { heroin injecting has been } \\
\text { offset by increased } \\
\text { amphetamine injecting" }\end{array}$ \\
\hline \multicolumn{7}{|c|}{ B. Studies that include outcomes for other non-opioid illicit drugs } \\
\hline $\begin{array}{l}\text { Heroin \& } \\
\text { opioid } \\
\text { outcomes } \\
\text { / Other } \\
\text { drug use }\end{array}$ & \begin{tabular}{|l} 
Day C., et. al. 2004. \\
"Effects of reduction in \\
heroin supply on injecting \\
drug use: Analysis of \\
data from needle and \\
syringe programmes." \\
British Medical Journal. \\
329(7463): 428-29.
\end{tabular} & \begin{tabular}{|l|} 
- Needles/ \\
syringes \\
distributed as a \\
measure of \\
injecting drug \\
use
\end{tabular} & \begin{tabular}{|l|}
2.25 \\
years
\end{tabular} & $\begin{array}{l}\text { - State-level } \\
\text { quarterly data }\end{array}$ & Descriptive & $\begin{array}{l}-28 \% \text { decrease in } \\
\text { needles/syringes distributed } \\
\text { from fourth quarter of } 2000 \text { to } \\
\text { first quarter } 2002\end{array}$ \\
\hline $\begin{array}{l}\text { Heroin \& } \\
\text { opioid } \\
\text { outcomes } \\
\text { / Other } \\
\text { drug use }\end{array}$ & $\begin{array}{l}\text { Degenhardt, L., et al. } \\
2005 \text {. "The impact of the } \\
\text { Australian heroin } \\
\text { shortage on demand for } \\
\text { and compliance with } \\
\text { treatment for drug } \\
\text { dependence." Drug and } \\
\text { Alcohol Dependence, } 79 \text { : } \\
\text { 129-135. }\end{array}$ & $\begin{array}{l}\text { - Number of } \\
\text { persons } \\
\text { entering } \\
\text { treatment for } \\
\text { drug addiction }\end{array}$ & $\begin{array}{l}2.25 \\
\text { years }\end{array}$ & \begin{tabular}{|l} 
- State-level \\
monthly \\
administrative data
\end{tabular} & $\begin{array}{l}\text { Time- } \\
\text { series } \\
\text { analyses }\end{array}$ & $\begin{array}{l}\text { - Decrease in number } \\
\text { entering opioid treatment } \\
\text { - Improvements in treatment } \\
\text { adherence and retention } \\
\text { - Small increases in } \\
\text { treatment for cocaine } \\
\text { dependence }\end{array}$ \\
\hline $\begin{array}{l}\text { Heroin \& } \\
\text { opioid } \\
\text { outcomes } \\
\text { / Other } \\
\text { drug use }\end{array}$ & $\begin{array}{l}\text { Degenhardt L., et al. } \\
2005 \text {. "Age differentials in } \\
\text { the impacts of reduced } \\
\text { heroin: Effects of a } \\
\text { "heroin shortage" in } \\
\text { NSW, Australia." Drug } \\
\text { and Alcohol dependence, } \\
2005 \text { 79(3): } 397-404 \text {. }\end{array}$ & $\begin{array}{l}\text { - Arrests for } \\
\text { heroin } \\
\text { possession } \\
\text { - Number of } \\
\text { drug-related } \\
\text { deaths } \\
\text { - Number of } \\
\text { persons } \\
\text { entering } \\
\text { treatment for } \\
\text { heroin, } \\
\text { amphetamine } \\
\text { dependence }\end{array}$ & 2.5 years & $\begin{array}{l}\text { - State-level } \\
\text { monthly } \\
\text { administrative data } \\
\text { by age }\end{array}$ & $\begin{array}{l}\text { Time- } \\
\text { series } \\
\text { analysis }\end{array}$ & $\begin{array}{l}-41 \% \text { reduction in new } \\
\text { registrations for opioid } \\
\text { pharmacotherapy for ages } \\
25-34 \text { years, a } 26 \% \\
\text { reduction for ages } 15-24 \\
\text { years, and no change for } \\
\text { ages } 35 \text { and older } \\
-49 \% \text { reduction in heroin } \\
\text { possession offenses for ages } \\
15-24 \text { years and } 31-40 \% \\
\text { decrease for those } 25 \text { and } \\
\text { older } \\
- \text { Large reduction in opioid- } \\
\text { related deaths } \\
- \text { No change in non-opioid } \\
\text { drug-related deaths } \\
\end{array}$ \\
\hline
\end{tabular}


Table B1 [Continued]: Studies of the effects of the Australian heroin supply reduction

\begin{tabular}{|c|c|c|c|c|c|c|}
\hline $\begin{array}{l}\text { Heroin \& } \\
\text { opioid } \\
\text { outcomes } \\
\text { / Other } \\
\text { drug use }\end{array}$ & $\begin{array}{l}\text { Roxburgh A., Degenhardt } \\
\text { L., and Breen C. } 2004 . \\
\text { "Changes in patterns of } \\
\text { drug use among injecting } \\
\text { drug users following a } \\
\text { reduction in the availability } \\
\text { of heroin in New South } \\
\text { Wales, Australia." Drug } \\
\text { and Alcohol Review, 23: } \\
287-94 \text {. }\end{array}$ & $\begin{array}{l}\text { - Self-reported } \\
\text { heroin use, } \\
\text { prices, } \\
\text { availability } \\
\text { - Self-reported } \\
\text { cocaine use, } \\
\text { prices, } \\
\text { availability }\end{array}$ & 3 years & $\begin{array}{l}\text { - Self-reports from } \\
\text { injecting drug } \\
\text { users (annual } \\
\text { cross-sections, } \\
\text { convenience } \\
\text { sampling) }\end{array}$ & Descriptive & $\begin{array}{l}\text { - Marked decrease in the } \\
\text { frequency of heroin use in } \\
2001, \text { stayed low in } 2002 \text { and } \\
2003 \\
\text { - injecting drug users shifted } \\
\text { from heroin to cocaine during } \\
2001 \text {, however, patterns of } \\
\text { cocaine use were not } \\
\text { maintained } \\
\text { - cocaine price has remained } \\
\text { stable }\end{array}$ \\
\hline $\begin{array}{l}\text { Heroin \& } \\
\text { opioid } \\
\text { outcomes } \\
\text { / Other } \\
\text { drug use }\end{array}$ & $\begin{array}{l}\text { Degenhardt L., et al. } \\
2005 \text {. "Patterns of illicit } \\
\text { drug use in NSW, } \\
\text { Australia following a } \\
\text { reduction in heroin } \\
\text { supply." International } \\
\text { Journal of Drug Policy, } \\
\text { 16(5):300-07. }\end{array}$ & $\begin{array}{l}\text { - Helpline calls } \\
\text { for heroin and } \\
\text { other drugs - - } \\
\text { Visits to inner } \\
\text { Sydney needle } \\
\text { syringe } \\
\text { program where } \\
\text { users reported } \\
\text { the last drug } \\
\text { injected }\end{array}$ & 3.5 years & $\begin{array}{l}\text { - Drug helpline } \\
\text { calls about } \\
\text { different drug } \\
\text { types } \\
\text { - Data from an } \\
\text { inner Sydney } \\
\text { needle and syringe } \\
\text { program }\end{array}$ & $\begin{array}{l}\text { Time- } \\
\text { series } \\
\text { analyses }\end{array}$ & $\begin{array}{l}\text { - } 39 \% \text { decline in calls of } \\
\text { concern related to heroin } \\
\text { from late } 2000 \text { to early } 2001 \\
\text { - Short-term increases in call } \\
\text { of } 75 \% \text { for } \\
\text { methamphetamine, } 191 \% \text { for } \\
\text { cocaine, no change for } \\
\text { benzodiazepines } \\
-40 \% \text { reduction in the total } \\
\text { number of needles and } \\
\text { syringes distributed }\end{array}$ \\
\hline $\begin{array}{l}\text { Other } \\
\text { drug use }\end{array}$ & $\begin{array}{l}\text { Snowball L, et al. } 2008 . \\
\text { "Did the heroin shortage } \\
\text { increase amphetamine } \\
\text { use? A time series } \\
\text { analysis." Crime and } \\
\text { Justice Bulletin, 114: 1-8. }\end{array}$ & $\begin{array}{l}\text { Arrests for } \\
\text { use/possession } \\
\text { of heroin or } \\
\text { amphetamines }\end{array}$ & $\begin{array}{l}6.25 \\
\text { years }\end{array}$ & $\begin{array}{l}\text { - State-level } \\
\text { monthly } \\
\text { administrative data }\end{array}$ & $\begin{array}{l}\text { Time- } \\
\text { series } \\
\text { analysis }\end{array}$ & $\begin{array}{l}\text { - No evidence of a temporal } \\
\text { relationship between heroin } \\
\text { and amphetamine use }\end{array}$ \\
\hline \multicolumn{7}{|c|}{ C. Studies that focus on health and mortality outcomes } \\
\hline $\begin{array}{l}\text { Health \& } \\
\text { mortality }\end{array}$ & $\begin{array}{l}\text { Degenhardt L., et al. } \\
2005 . \text { The effect of a } \\
\text { reduction in heroin supply } \\
\text { on fatal and non-fatal } \\
\text { drug overdoses in New } \\
\text { South Wales, Australia. } \\
\text { Medical Journal of } \\
\text { Australia. 182(1): } 20-23 \text {. }\end{array}$ & $\begin{array}{l}\text { - Drug-related } \\
\text { deaths } \\
\text { - Ambulance } \\
\text { calls to opioid } \\
\text { overdoses } \\
\text { - Hospital } \\
\text { admissions for } \\
\text { heroin and } \\
\text { other drug } \\
\text { overdoses }\end{array}$ & $\begin{array}{l}2.33 \\
\text { years; }\end{array}$ & \begin{tabular}{|l} 
- State-level \\
monthly \\
administrative data
\end{tabular} & $\begin{array}{l}\text { Time- } \\
\text { series } \\
\text { analyses }\end{array}$ & $\begin{array}{l}\text { Reduction in heroin-related } \\
\text { overdose events and deaths, } \\
\text { greatest among younger age } \\
\text { groups } \\
\text { - Increases in. non-fatal } \\
\text { overdoses with cocaine, } \\
\text { methamphetamines or } \\
\text { benzodiazepines }\end{array}$ \\
\hline $\begin{array}{l}\text { Health \& } \\
\text { mortality }\end{array}$ & $\begin{array}{l}\text { Day C., et al. 2005. "The } \\
\text { impact of changes to } \\
\text { heroin supply on blood- } \\
\text { borne virus notifications } \\
\text { and injecting related } \\
\text { harms in New South } \\
\text { Wales, Australia." BMC } \\
\text { Public Health. 5(1):1-8. }\end{array}$ & $\begin{array}{l}\text { - HIV, hepatitis } \\
\text { B, hepatitis C } \\
\text { notifications } \\
\text { - Hospital and } \\
\text { emergency } \\
\text { department } \\
\text { admissions for } \\
\text { injection- } \\
\text { related } \\
\text { problems } \\
\end{array}$ & 2.5 years & $\begin{array}{l}\text { - State-level } \\
\text { monthly } \\
\text { administrative data }\end{array}$ & $\begin{array}{l}\text { Time- } \\
\text { series } \\
\text { analysis }\end{array}$ & $\begin{array}{l}\text { - No changes detected in } \\
\text { hospital visits for injection- } \\
\text { related problems } \\
\text { - No significant change } \\
\text { detected for HIV and } \\
\text { hepatitis B notifications } \\
\text { - Potentially a delayed } \\
\text { reduction in hepatitis C } \\
\text { notifications, restricted to } \\
\text { patients aged } 15-19 \text { years }\end{array}$ \\
\hline \multicolumn{7}{|c|}{ D. Studies that include non-drug criminal offending outcomes } \\
\hline $\begin{array}{l}\text { Heroin \& } \\
\text { opioid } \\
\text { outcomes } \\
\text { / Other } \\
\text { drug use / } \\
\text { Crime }\end{array}$ & $\begin{array}{l}\text { Gilmour S., et al. } 2006 . \\
\text { "Identification and } \\
\text { quantification of change } \\
\text { in Australian illicit drug } \\
\text { markets." BMC Public } \\
\text { Health, 6(200). }\end{array}$ & $\begin{array}{l}\text { - Heroin and } \\
\text { other drug } \\
\text { possession } \\
\text { offenses } \\
\text { - Ambulance } \\
\text { attendances for } \\
\text { drug overdoses } \\
\text { - Drug helpline } \\
\text { calls } \\
\text { - Property, } \\
\text { robbery, } \\
\text { prostitution } \\
\text { offenses }\end{array}$ & 1.5 years & $\begin{array}{l}\text { - State-level } \\
\text { monthly } \\
\text { administrative data }\end{array}$ & $\begin{array}{l}\text { - Times } \\
\text { series and } \\
\text { principal } \\
\text { component } \\
\text { analysis }\end{array}$ & $\begin{array}{l}\text { - Used the data series to } \\
\text { assess whether the changes } \\
\text { to the heroin market in } 2001 \\
\text { could be attributed to } \\
\text { "normal" drug epidemic } \\
\text { processes } \\
\text { - Found change at start of } \\
\text { the heroin supply reduction is } \\
\text { three times larger than } \\
\text { variation found in other } \\
\text { epidemic processes within } \\
\text { the data }\end{array}$ \\
\hline
\end{tabular}


Table B1 [Continued]: Studies of the effects of the Australian heroin supply reduction

\begin{tabular}{|c|c|c|c|c|c|c|}
\hline $\begin{array}{l}\text { Heroin \& } \\
\text { opioid } \\
\text { outcomes } \\
\text { / Crime }\end{array}$ & $\begin{array}{l}\text { Degenhardt, L., et al. } \\
2005 \text {. "The effect of a } \\
\text { reduction in heroin supply } \\
\text { in Australia upon drug } \\
\text { distribution and } \\
\text { acquisitive crime." British } \\
\text { Journal of Criminology, } \\
\text { 45: } 2-24 \text {. }\end{array}$ & $\begin{array}{l}- \text { - Police } \\
\text { incidents for } \\
\text { drug } \\
\text { possession (by } \\
\text { drug type), } \\
\text { robbery, break } \\
\text { and enter, and } \\
\text { theft }\end{array}$ & 2 years & $\begin{array}{l}\text { - State-level } \\
\text { monthly } \\
\text { administrative data } \\
\text { by sex } \\
\text { - Police } \\
\text { investigation } \\
\text { reports } \\
\text { - Interviews with } \\
\text { health/ law } \\
\text { enforcement } \\
\text { professionals, } \\
\text { heroin users }\end{array}$ & $\begin{array}{l}\text { Time- } \\
\text { series } \\
\text { analyses }\end{array}$ & $\begin{array}{l}\text { - Significant decreases in } \\
\text { police incidents of heroin } \\
\text { possession } \\
\text { - Increase observed for } \\
\text { cocaine possession } \\
\text { - Decrease in theft and } \\
\text { temporary increase in } \\
\text { robbery }\end{array}$ \\
\hline $\begin{array}{l}\text { Other } \\
\text { drug use / } \\
\text { Crime }\end{array}$ & $\begin{array}{l}\text { Degenhardt L., et al. } \\
2005 \text {. "Was an increase } \\
\text { in cocaine use in New } \\
\text { South Wales, Australia, } \\
\text { accompanied by an } \\
\text { increase in violent } \\
\text { crime?" BMC Public } \\
\text { Health 5(40). }\end{array}$ & $\begin{array}{l}\text { - Self-reported } \\
\text { cocaine use } \\
\text { - Robberies } \\
\text { with weapons }\end{array}$ & $2-3$ years & $\begin{array}{l}\text { - Self-reports from } \\
\text { injecting drug } \\
\text { users (annual } \\
\text { cross-sections, } \\
\text { convenience } \\
\text { sampling) } \\
\text { - State-level } \\
\text { monthly data on } \\
\text { drug, property and } \\
\text { robbery offenses } \\
\text { - Interviews with } \\
\text { health/law } \\
\text { enforcement } \\
\text { professionals }\end{array}$ & $\begin{array}{l}\text { Time- } \\
\text { series } \\
\text { analysis }\end{array}$ & $\begin{array}{l}\text { - There was a significant } \\
\text { increase in cocaine use and } \\
\text { cocaine possession offences } \\
\text { in first few months } \\
\text { - There was also an increase } \\
\text { in incidents of robbery where } \\
\text { weapons were involved } \\
\text { - There were no increases in } \\
\text { offences involving firearms, } \\
\text { homicides or reported } \\
\text { assaults }\end{array}$ \\
\hline $\begin{array}{l}\text { Heroin \& } \\
\text { opioid } \\
\text { outcomes } \\
\text { / Other } \\
\text { drug use / } \\
\text { Crime }\end{array}$ & $\begin{array}{l}\text { Smithson M., et al. } 2004 . \\
\text { "The impact of illicit drug } \\
\text { supply reduction on } \\
\text { health and social } \\
\text { outcomes: The heroin } \\
\text { shortage in the Australian } \\
\text { Capital Territory." } \\
\text { Addiction } 99(3): 340-8 .\end{array}$ & $\begin{array}{l}\text { - Ambulance } \\
\text { callouts for } \\
\text { heroin and } \\
\text { other drugs } \\
\text { overdoses } \\
\text { - Numbers in } \\
\text { medication- } \\
\text { assisted } \\
\text { treatment } \\
\text { - Property } \\
\text { crime }\end{array}$ & 2.3 years & $\begin{array}{l}\text { - Territory-level } \\
\text { monthly } \\
\text { administrative data }\end{array}$ & $\begin{array}{l}\text { Time- } \\
\text { series } \\
\text { analysis }\end{array}$ & $\begin{array}{l}\text { - Reduction in heroin purity } \\
\text { predicted decline in heroin- } \\
\text { related ambulance callouts } \\
\text { and an increase in treatment } \\
\text { program enrolments } \\
\text { - No evidence of increase in } \\
\text { callouts for other drugs } \\
\text { - Declines in robbery and } \\
\text { burglary, but not theft }\end{array}$ \\
\hline $\begin{array}{l}\text { Heroin \& } \\
\text { opioid } \\
\text { outcomes } \\
\text { / Other } \\
\text { drug use / } \\
\text { Crime }\end{array}$ & $\begin{array}{l}\text { Degenhardt, L., et al. } \\
\text { 2005. "Effects of a } \\
\text { sustained heroin } \\
\text { shortage in three } \\
\text { Australian States." } \\
\text { Addiction, 100: 908-20. }\end{array}$ & $\begin{array}{l}\text { - Drug } \\
\text { overdoses } \\
\text { - Police } \\
\text { incidents for } \\
\text { drug } \\
\text { possession and } \\
\text { property crime } \\
\text { - Drug } \\
\text { treatment } \\
\text { episodes } \\
\text { - Needles } \\
\text { distributed to } \\
\text { injecting drug } \\
\text { users }\end{array}$ & 3 years & $\begin{array}{l}\text { - State-level } \\
\text { monthly } \\
\text { administrative data } \\
\text { from three states } \\
\text { (NSW, VIC, SA) }\end{array}$ & $\begin{array}{l}\text { Time- } \\
\text { series } \\
\text { analyses }\end{array}$ & $\begin{array}{l}\text { - Fatal and non-fatal heroin } \\
\text { overdoses decreased by } 40 \text { - } \\
85 \% \\
\text { - No significant increases in } \\
\text { cocaine, methamphetamine } \\
\text { or benzodiazepine overdose } \\
\text { events } \\
\text { - Drop in number of needles } \\
\text { and syringes distributed in } \\
\text { VIC } \\
\text { - Short-term increase in } \\
\text { property crime followed by a } \\
\text { reduction in NSW }\end{array}$ \\
\hline $\begin{array}{l}\text { Heroin \& } \\
\text { opioid } \\
\text { outcomes } \\
\text { / Other } \\
\text { drug use / } \\
\text { Crime }\end{array}$ & $\begin{array}{l}\text { Donnelly, N., } \\
\text { Weatherburn, D., and } \\
\text { Chilvers, M. 2004. "The } \\
\text { Impact of the Australian } \\
\text { Heroin Shortage on } \\
\text { robbery in NSW." Crime } \\
\text { and Justice Statistics } \\
\text { Bureau Brief. Sydney: } \\
\text { NSW Bureau of Crime } \\
\text { Statistics and Research. }\end{array}$ & $\begin{array}{l}\text {-Arrests for } \\
\text { drug } \\
\text { possession } \\
\text { - Non-fatal } \\
\text { opioid } \\
\text { overdoses } \\
\text { - Reported } \\
\text { robberies }\end{array}$ & 3 years & $\begin{array}{l}\text { - District- and } \\
\text { state-level monthly } \\
\text { administrative data }\end{array}$ & $\begin{array}{l}\text { Time- } \\
\text { series } \\
\text { analysis }\end{array}$ & $\begin{array}{l}\text { - Decrease in heroin } \\
\text { overdoses } \\
\text { - Decreases in the majority of } \\
\text { property crime categories } \\
\text { - Short-term increase in } \\
\text { robbery followed by a } \\
\text { decrease }\end{array}$ \\
\hline
\end{tabular}




\section{Appendix C: Net Present Value Calculations}

We convert the mortality and crime estimates to dollar values and calculate their net present value at the start of the heroin supply reduction. Here, we provide more information about the basis for the valuations, including the sources used and how the calculations are made. It is important to note that no value is attributed to drug-defined crimes, which includes drug use/possession offenses and drug supply offenses.

Mortality costs. We value mortality changes using value of a statistical life (VSL) estimates. US estimates are currently on the order of US\$10 million (Kniesner and Viscusi 2019). Viscusi (2018) considers Australian and international evidence on the likely VSL for Australia, and estimates that it is around $\mathrm{A} \$ 10$ million in 2015 dollars. This is approximately A $\$ 10.9$ million in 2019 dollars when updated using Australia's average wage index for all industries (Australian Bureau of Statistics 2020).

This estimate is higher than the VSL valuation of $\mathrm{A} \$ 4.9$ million used by the Australian Government (2019), which is an updated estimate from Abelson (2007). However, Abelson (2007) is based on a review of international research estimates rather than from primary data analysis, and that review does not use recent international estimates. For further comparison, the Viscusi (2018) estimate is around $20 \%$ higher than a 2006 VSL estimate for the Australasian Railway Association by Tooth (2010), and around 20\% lower than the Australian VSL estimate from Viscusi and Masterman (2017), who propose scaling estimates from the US to other countries using income elasticities. (In both cases, the comparison is after exchange rate conversions and adjusting to 2019 Australian dollars using the average wage index described above.) As such, the Viscusi (2018) VSL estimate seems appropriate for our purposes.

Crime costs. There are many different types of costs associated with crimes. These include tangible costs to victims (e.g., property losses, medical bills), victims' pain and suffering, and costs to the community such as those associated with crime prevention, insurance and precautionary behavior. Studies have estimated the costs of crime for several countries, including a series of studies from the Australian Institute of Criminology that have estimated the crime costs for Australia (Mayhew 2003; Rollings 2008; Smith et al. 2014). The methodology applied has been consistent and similar to that developed for Britain (Brand and Price 2000) and the United States (Cohen and Bowles 2010). For different types of crime, the authors estimate medical costs, lost earnings and intangible costs to arrive at a per-crime cost estimate. They then use nationally representative victimization surveys to estimate the degree to which crimes are under-reported, and use this multiplier to scale up the number of crimes reported to police.

We take the per-crime estimates from Smith et al. (2014), as this provides the most recent cost information. These are for 2011, so we adjust them to 2019 dollar using the Australian wage index. We use their estimates for the costs of assault (A $\$ 4,833$ per crime); sexual assault ( $\$ 5,016$ per crime); robbery (A $\$ 4,479$ per crime); burglary/break and enter (for breaking into residences - A $\$ 3,516$ per crime); motor vehicle theft (A $\$ 7,845$ per crime); fraud ( $\mathrm{A} \$ 16,265$ per crime); and other theft ( $\mathrm{\$} \$ 716$ per crime); and value other types of violent crime based on assaults without injury (A $\$ 538$ per crime). For homicides, we use the same 2019 value of a life based on Viscusi (2018) that is used for the other mortality effects. Multipliers for the under-reporting of the different crime categories are taken from Mayhew (2003). These are for 2001, so are better than later estimates if the degree of under-reporting changes over time. The only relevant crime category not included in Mayhew (2003) is fraud, so we take that underreporting estimate from Smith et al. (2014).

Victims' pain, suffering and other intangible costs are difficult to estimate, so we also report an adjusted approach to valuing the costs of crime. Estimates have been taken from jury awards of damages for violent crime, from contingent valuation studies, and other methods like estimating the change in mental health 
after a violent crime and valuing it using quality-adjusted life years (Bindler, Ketel and Hjalmarsson 2020; Cohen and Bowles 2010). Mayhew (2003) and Smith et al. (2014) use contingent valuation estimates from UK studies that are low relative to recent estimates in the literature. To address this concern, we replace the intangible victim costs with estimates from Johnston, Shields and Suziedelyte (2018). The authors use nationally representative panel data from Australia to estimate that A $\$ 88,000$ income is required to return victims of violent crime to their prior level of wellbeing. This is in 2012 dollars, so we again convert it to 2019 dollars using the Australian wage index. The question used to identify victims of violent crime is quite general, asking respondents if they were a "victim of physical violence (e.g., assault)." We therefore apply this valuation to all violent crimes including robbery, except for homicides, by replacing the intangible victim costs used in Smith et al. (2014) (and keeping all of the other elements the same).

Estimating the net present value. We calculate the change in the number of deaths and each type of crime by multiplying the number of individuals in our treatment sample by the annual point estimates from our equation (2) specification (i.e., event study with a comparison group). We then multiply those quantities by the per-death and per-crime costs outlined above, and aggregate the costs for each year after the onset of the heroin supply reduction.

The net value in each of the eight years are presented in Figure C1. The annual values based on the initial cost estimates are shown with a dashed line, while the values estimated with thOpe higher intangible victim costs from Johnson, Shields and Suziedelyte (2018) are shown with a bold line. With the initial approach, there are net reductions in mortality and crime costs in each of the eight years after the heroin supply reduction. They range from savings of $\mathrm{A} \$ 268$ million in the first year to savings of $\mathrm{A} \$ 862$ million in the eighth year. With the second approach that includes newer estimates of victimization costs, the net value in the first year after the heroin supply reduction changes from to a net saving of $\mathrm{A} \$ 268$ million to a net cost of $\mathrm{A} \$ 244$ million. There are estimated savings in the other years of between $\mathrm{A} \$ 284$ and $\mathrm{A} \$ 809$ million. The net value in the first year is sensitive to how violent crime costs are assessed, because that is the year when violent crime spikes, but in other years the estimates change very little.

Figure C1: Annual net value of mortality and crime effects

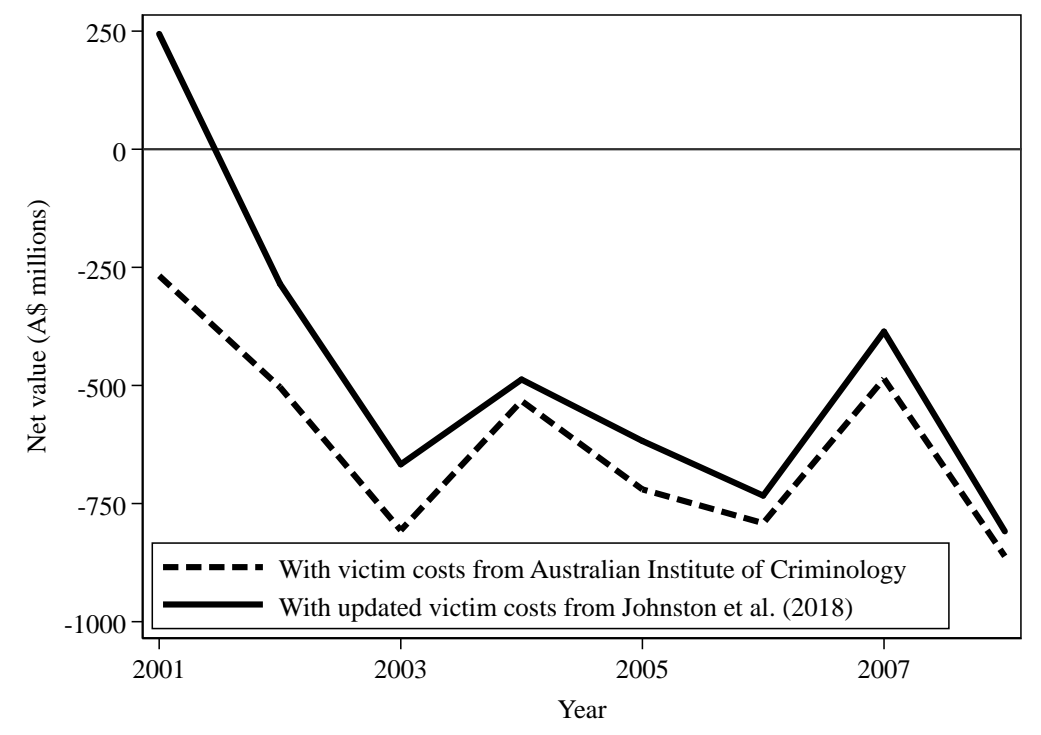




\section{Appendix C: Net Present Value Calculations}

\section{Appendix C References}

Abelson, Peter. 2007. Establishing a monetary value for lives saved: Issues and controversies, Working Papers in Cost Benefit Analysis No. 2008-2. Canberra: Australian Government Department of Finance and Deregulation. https://www.pmc.gov.au/sites/default/files/ publications/Working_paper_2_Peter_Abelson.pdf.

Australian Bureau of Statistics. 2020. Wage Price Index, Australia, Catalogue Number 6345.0. Canberra: Australian Bureau of Statistics. https:

//www.abs.gov.au/AUSSTATS/abs@.nsf/DetailsPage/6345.0Mar\%202020?OpenDocument.

Australian Government. 2019. Best Practice Regulation Guidance Note: Value of Statistical Life. Canberra: Australian Government Department of the Prime Minister and Cabinet, Office of Best Practice Regulation. https://www.pmc.gov.au/sites/default/files/publications/value-of-statistical -life-guidance-note_0_0.pdf

Bindler, Anna, Randi Hjalmarsson, and Nadine Ketel. 2020. Costs of victimization. In: David Marcotte and Klaus Zimmermann (eds) Handbook of Labor, Human Resources and Population Economics. Cham Switzerland: Springer Nature.

Brand, Sam, and Richard Price. 2000. The economic and social costs of crime. Home Office Research Study 217. London: Home Office.

Cohen, Mark A., and Roger Bowles. 2010. Estimating costs of crime. In Alex R. Piquero and David Weisburd (eds), Handbook of Quantitative Criminology. New York: Springer.

Johnston, David, Michael Shields and Agne Suziedelyte. 2018. Victimisation, well-being and compensation: Using panel data to estimate the cost of violent crime. Economic Journal 128(611): 1545-1569.

Mayhew, Pat. 2003. Counting the costs of crime in Australia: Technical report. AIC Technical and Background Paper Series No. 4. Canberra: Australian Institute of Criminology.

Rollings, Kiah. 2008. Counting the costs of crime in Australia: A 2005 update. Research and Public Policy Series No. 91. Canberra: Australian Institute of Criminology. http://www.aic.gov.au/publications/current\%20series/rpp/81-99/rpp91.html

Smith, Russell G., Penny Jorna, Josh Sweeney and Georgina Fuller. 2014. Counting the costs of crime in Australia: A 2011 estimate. AIC Research and Public Policy Series No. 129. Canberra: Australian Institute of Criminology.

Tooth, Richard. 2010. The cost of road crashes: A review of key issues. LECG Report for the Australasian Railway Association. https://ara.net.au/sites/default/files/TheCostofRoadCrashesReport.pdf

Viscusi, W. Kip. 2018. Pricing lives: International guideposts for safety. Economic Record 94: 1-10. Viscusi, W. Kip, and Thomas J. Kniesner. 2019. The value of a statistical life. Oxford Research Encyclopedia of Economics and Finance, forthcoming.

Viscusi, W. Kip, and Clayton J. Masterman. 2017. Income elasticities and global values of a statistical life. Journal of Benefit-Cost Analysis, 8(2):226-250. 